Fabiane dos Santos

(Organizadora)

\section{Geografia no Século XXI Volume 6}

1a Edição

Belo Horizonte

Poisson

2020 
Editor Chefe: Dr. Darly Fernando Andrade

\section{Conselho Editorial}

Dr. Antônio Artur de Souza - Universidade Federal de Minas Gerais

Ms. Davilson Eduardo Andrade

Dra. Elizângela de Jesus Oliveira - Universidade Federal do Amazonas

Msc. Fabiane dos Santos

Dr. José Eduardo Ferreira Lopes - Universidade Federal de Uberlândia

Dr. Otaviano Francisco Neves - Pontifícia Universidade Católica de Minas Gerais

Dr. Luiz Cláudio de Lima - Universidade FUMEC

Dr. Nelson Ferreira Filho - Faculdades Kennedy

Ms. Valdiney Alves de Oliveira - Universidade Federal de Uberlândia

Dados Internacionais de Catalogação na Publicação (CIP)

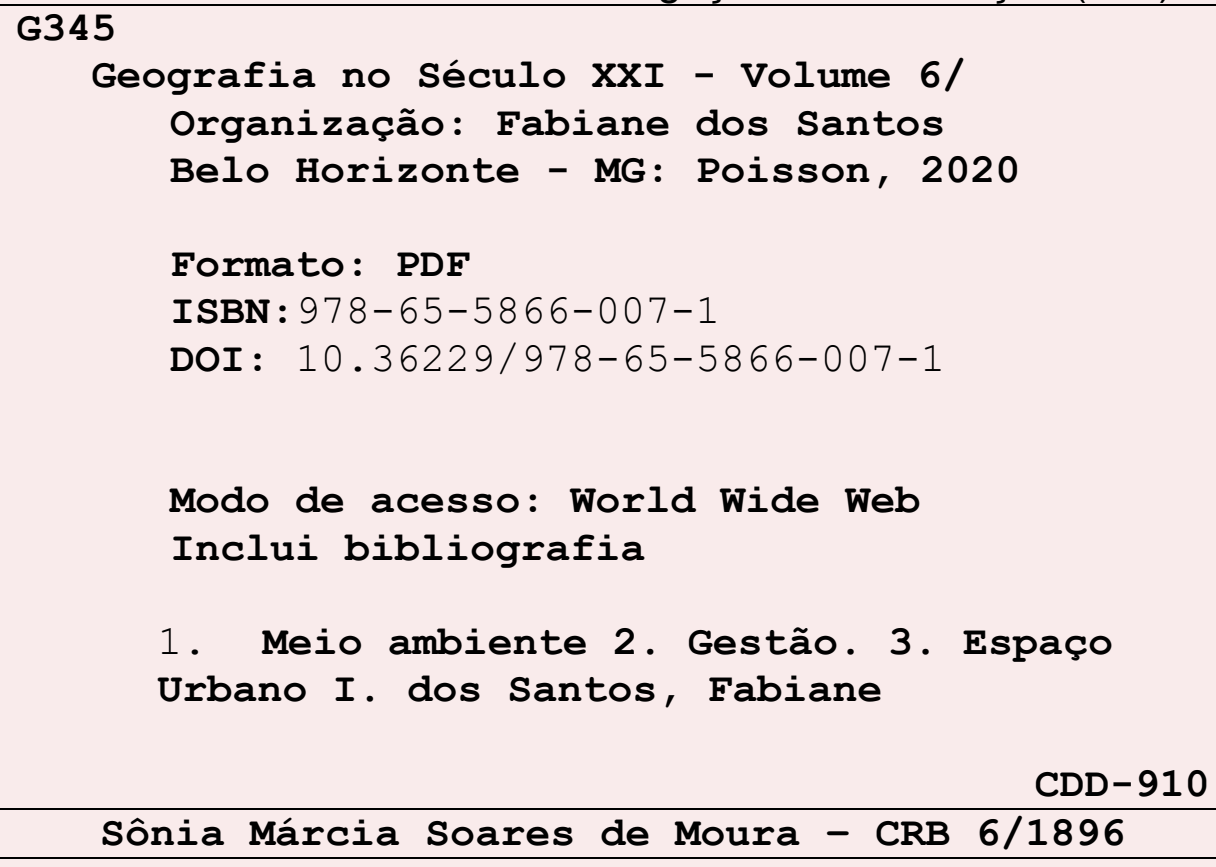

O conteúdo dos artigos e seus dados em sua forma, correção e confiabilidade são de responsabilidade exclusiva dos seus respectivos autores.

Baixe outros títulos gratuitamente em

www.poisson.com.br

contato@poisson.com.br 


\section{SUMÁRIO}

Capítulo 1: Análise morfométrica da Bacia Hidrográfica do Rio Subaúma-BA. 06 Amom Chrystian de Oliveira Teixeira, Maria Elisa Zanella, Mauricio Santana Moreau, Thiara Messias de Almeida Teixeira

DOI: 10.36229/978-65-5866-007-1.CAP.01

Capítulo 2: Meio ambiente, civilização e espaço geográfico. Ecovilas genuínas e o modo de ser e habitar zeloso.. 13

Severiano José dos Santos Júnior, Catherine Prost, Roberto Bartholo

DOI: 10.36229/978-65-5866-007-1.CAP.02

Capítulo 3: Contexto territorial e ambiental no Programa de Uso Público do PESM: A visão institucional 20

Davis Gruber Sansolo, Sidnei Raimundo, Eliane Simões, Juliana Marcondes Bussolotti

DOI: 10.36229/978-65-5866-007-1.CAP.03

Capítulo 4: Os conhecimentos climáticos nos livros didáticos de Geografia do Ensino Fundamental 26

Thiago Amancio Gonçalves, Thiara Messias de Almeida Teixeira, Amom Chrystian de Oliveira Teixeira DOI: 10.36229/978-65-5866-007-1.CAP.04

Capítulo 5: Geografia, gabinete e empiria: Um estudo sobre as potencialidades do trabalho de campo - Apreciações de uma festividade católica . 33

Luís Ricardo Soares Wenceslau, Emerson Costa de Melo, Jeferson José de Oliveira Pinheiro

DOI: 10.36229/978-65-5866-007-1.CAP.05

Capítulo 6: Identidade, Simbolismo e Pertencimento: 0 caso da Região Missioneira44 Luiz Felipe Sausen de Freitas, Iolanda Lopes de Oliveira, Vera Maria Favila Miorin DOI: 10.36229/978-65-5866-007-1.CAP.06

Capítulo 7: Geograficidade no Bumba Meu Boi do Maranhão à luz da memória de brincantes.

Luciléa Ferreira Lopes Gonçalves, Salete Kozel Teixeira, Allison Bezerra Oliveira

DOI: 10.36229/978-65-5866-007-1.CAP.07 


\section{SUMÁRIO}

Capítulo 8: Da Centralidade Simbólica a Centralidade Socioterritorial de Macapá na Amazônia Setentrional Amapaense

Alex de Lima Santos, João Paulo de Almeida Amorim, Júlia Diniz de Oliveira, Élida Thalita Silva de Carvalho, Diogo Bernardino Santos de Medeiros

DOI: 10.36229/978-65-5866-007-1.CAP.08

Capítulo 9: A Produção do Espaço Urbano: Análise geográfica do bairro Flutuante na cidade de Tapauá-AM.

Abraão Ferreira Zuza, Eubia Andréa Rodrigues

DOI: 10.36229/978-65-5866-007-1.CAP.09

Capítulo 10: "Terra de Nhá Chica”: Contradições inerentes à prática turística 84

Magno Angelo Kelmer, Carlos Eduardo Santos Maia

DOI: 10.36229/978-65-5866-007-1.CAP.10

Autores: 


\section{Capítulo 1}

\section{Análise morfométrica da Bacia Hidrográfica do Rio Subaúma-BA}

\section{Amom Chrystian de Oliveira Teixeira \\ Maria Elisa Zanella \\ Mauricio Santana Moreau \\ Thiara Messias de Almeida Teixeira}

Resumo: 0 trabalho objetivou a setorização e a caracterização morfométrica da Bacia Hidrográfica do Rio Subaúma (BHRS), localizada no Litoral Norte da Bahia, que drena uma área de $1.555 \mathrm{~km}^{2}$ e tem como principais usos da terra a pecuária de bovinos, a eucaliptocultura e a citricultura. Foram utilizadas imagens SRTM e ASTER como fonte de dados, que no software Arcgis 9.3, auxiliaram na delimitação, setorização e obtenção dos parâmetros morfométricos, tais como: área, perímetro, comprimento do eixo principal e da rede de drenagem, compacidade, circularidade, elongação, sinuosidade e densidade de drenagem, utilizando equações consagradas na literatura correlata. Os resultados mostram que a BHRS é exorréica, com padrão dendrítico, possui baixa densidade de drenagem e baixo índice de circularidade. A análise dos resultados revela uma bacia hidrográfica com relevo que implica em baixos riscos de inundação e altas tendências de infiltração em detrimento do escoamento superficial.

Palavras-chave:Recursos hídricos, morfometria, setorização de bacias, processos hidrológicos, geoprocessamento. 


\section{INTRODUÇÃO}

Dentre os recursos naturais, a água é provavelmente um dos mais importantes para a humanidade, não apenas pela sua participação nos processos biológicos, mas também por estar associadas a todos os aspectos sociais, econômicos e culturais. Tendo em vista essa importância, bem como a crescente demanda pelo seu uso e os impactos ambientais gerados, surge a necessidade de estudos que balizem uma utilização racional deste recurso, bem como um manejo eficaz das atividades ligadas aos recursos hídricos.

Nesse contexto, o conceito de Bacia Hidrográfica adquire destaque dada a possibilidade da visualização e análise das inter-relações dos elementos e fluxos em seu interior, e da troca de matéria e energia do sistema com o exterior. A caracterização morfométrica de uma Bacia Hidrográfica é um dos primeiros e mais comuns procedimentos executados em análises hidrológicas ou ambientais, e tem como objetivo elucidar as várias questões relacionadas com o entendimento da dinâmica ambiental local e regional (TEODORO et al., 2007).

Do ponto de vista evolutivo da paisagem, embora as sociedades possam por meio do trabalho alterar os atributos morfométricos das Bacias Hidrográficas (COLLARES, 2000), estes são componentes do sistema que alteram-se mais frequentemente a longo prazo, por estarem associados, principalmente a elementos mais estáveis da paisagem. Os atributos morfométricos relacionam-se com a fragilidade do sistema, principalmente por estarem ligados aos fluxos de matéria (água e sedimentos) dentro do sistema, à redistribuição da energia cinética das precipitações e por exercerem influência nos microclimas da bacia (temperatura, precipitação, evaporação, etc).

Diversos autores enfatizam a importância desses atributos na resposta hidrológica do cursos fluviais às precipitações, com papel na recepção das precipitações e no escoamento do fluxo de água até o canal fluvial principal e daí ao output da bacia (FREITAS, 1952; CHRISTOFOLETTI, 1969; GANDOLFI, 1971; COLLARES, 2000; MOSCA, 2003). Essa influência é notada também no tempo de concentração dos fluxos de água, ou seja, o tempo necessário para que toda a bacia contribua com esse deflúvio após o início da precipitação e desta forma a ocorrência de enchentes na bacia (VILLELA e MATTOS, 1975).

Diante do exposto, este trabalho utiliza ferramentas de geoprocessamento para caracterizar os aspectos morfométricos da Bacia Hidrográfica do Rio Subaúma (BHRS), localizada no Litoral Norte da Bahia, e realiza a setorização da bacia, buscando relaciona-los aos demais elementos ambientais.

\section{MATERIAIS E MÉTODOS}

\section{1 ÁREA DE ESTUDO}

Drenando uma área de pouco mais de 155 mil hectares, a BHRS se localiza nas coordenadas geográficas 38²9'3"W e 1151'52"S, ocupando área dos municípios de Água Fria, Alagoinhas, Araçás, Aramari, Cardeal da Silva, Entre Rios, Esplanada, Inhambupe, Itanagra e Ouriçangas, no Litoral Norte do estado da Bahia (Figura 1), inserindo-se na Região de Planejamento e Gestão da Água (RPGA) do Recôncavo Norte (Região XI), que por sua vez faz parte da Bacia Atlântico Sul, Trecho Leste, segundo a classificação oficial, adotada pelo Brasil para as Bacias Hidrográficas do território nacional.

Tem como usos da terra predominantes a pecuária de bovinos, a eucaliptocultura e a citricultura. Em sua constituição geológica predominam amplas áreas de coberturas sedimentares terciárias sobrepostas, em geral, bastante profundas, pouco coesas e com alto grau de permeabilidade, intercalando-se camadas com diferentes níveis de coesão, propiciando com isso excelentes condições para acumulação de minerais tais como petróleo e água. 0 relevo é plano a suave-ondulado, predominando áreas de Tabuleiros Costeiros, onde desenvolveram-se solos das classes dos Argissolos, Latossolos e Neossolos Quartzarênicos.

A integração dos atributos do relevo e geologia às condições climáticas da maior parte da BHRS, tais como as altas taxas pluviométricas bem distribuídas ao longo de todo ano e temperaturas que permitem a formação de excedentes hídricos, propiciam a formação de reservatórios de água subterrânea, tais como o aquífero São Sebastião, o maior da Bahia e um dos maiores do país.

Por outro lado, essas mesmas caraterísticas pedológicas, geomorfológicas e litológicas apontam a vulnerabilidade do solo à erosão pluvial, representando vetor risco para a diminuição da qualidade dos recursos hídricos. Além disso, os solos bastante pobres tornam necessárias práticas agrícolas que incluem correção química. Essa característica aliada as condições de porosidade vulnerabilizam os corpos hídricos subterrâneos e superficiais à contaminação pelos insumos agrícolas. 
Figura 1 - Localização e delimitação da Bacia Hidrográfica do Rio Subaúma - BA.

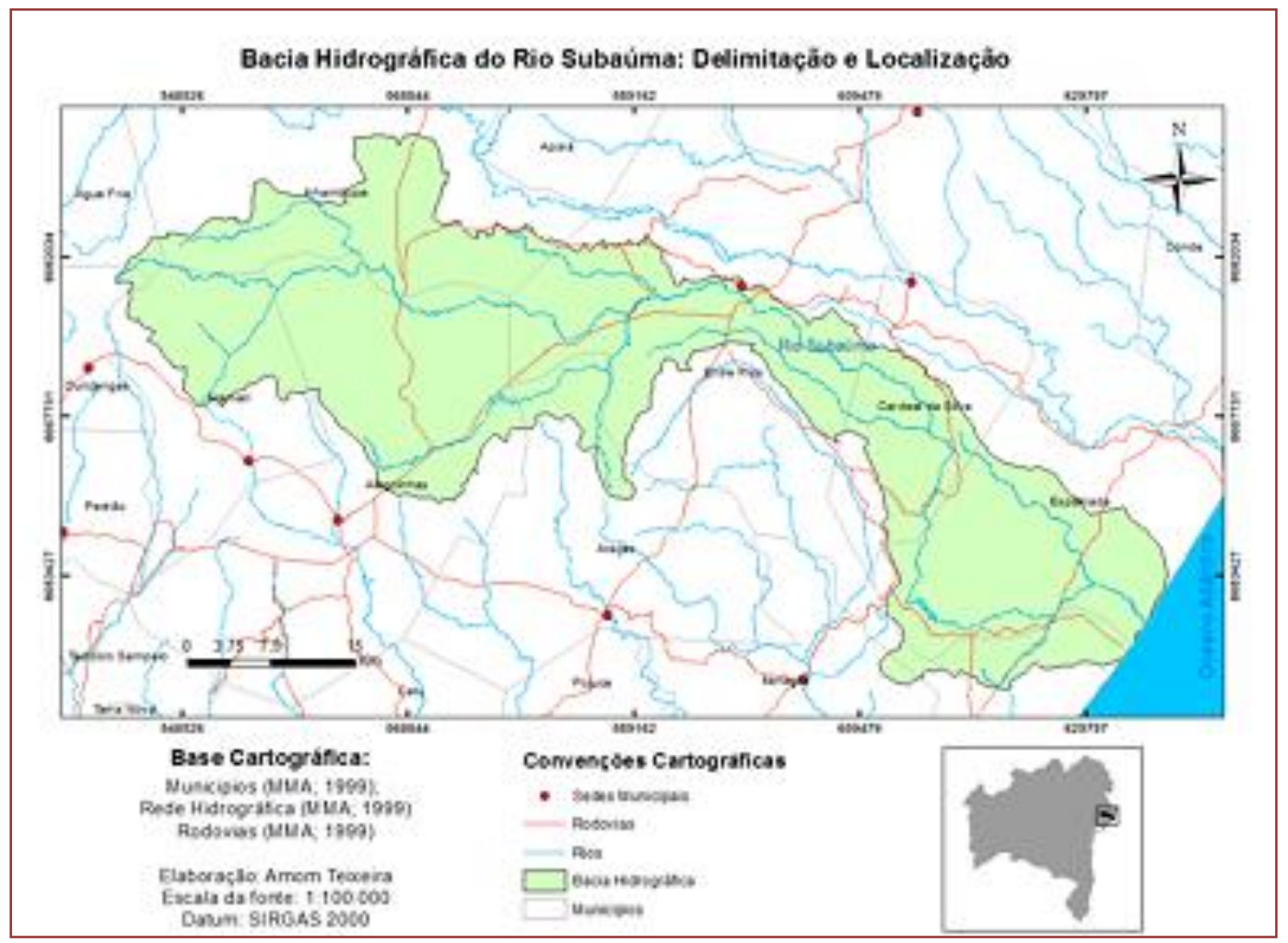

\subsection{SETORIZAÇÃO E CARACTERIZAÇÃO MORFOMÉTRICA}

A BHRS foi delimitada utilizando como base a superfície de captação e direcionamento da água e as estruturas que limitam essa superfície, separando-a da superfície dos sistemas vizinhos. A separação da Bacia Hidrográfica para fins de manejo da água superficial é realizada através da identificação dos divisores de água, definidos como o conjunto das partes mais altas do relevo que atuam no direcionamento das fluxos de água para curso principal do rio.

A discretização dos divisores de água foi realizada através da análise de dados gerados pelo projeto SRTM (Shuttle Radar Topography Mission), folhas SD-24-X-A e SD-24-Z-C, com resolução espacial de 90 metros quadrados (gerando mapas com resolução de 1:250.000) e dos dados do ASTER, folhas S12W038, S12W039, S13W038 e S13W039 com resolução espacial de 30 metros (gerando mapas com resolução de 1:100.000).

As imagens foram corrigidas, ortoretificadas em ambiente ArcGIS 9.3, previamente configurado no sistema geodésico de referência (Datum) Sirgas 2000, Zona 24S (UTM), utilizando para isso pontos de localizações conhecidas do terreno, pontos localizados em campo com auxílio do GPS e a comparação com feições de imagens dos satélites Landsat 7 e CBERS 2, com vistas a aumentar a precisão dos mapas. A interpretação das imagens foi realizada de forma automática por meio da extensão 3D Analyst do software ArcGIS 9.3, gerando um Modelo Numérico do Terreno (MNT), a partir do qual foi possível a identificação dos divisores de água da bacia.

Em ambiente ArcGIS foi realizada, no MNT, a identificação dos fluxos de água, dos principais cursos fluviais da bacia e então dos divisores de água. De posse destas informações, foi realizada a delimitação da BHRS por meio da extensão Spatial Analist.

A setorização da BHRS foi realizada pela identificação dos pontos de ruptura de declive (knick points), das modificações no relevo e dos estoques de massa disponíveis para erosão, através dos quais foram estabelecidos 3 setores denominados alto, médio e baixo curso da BHRS. Quanto a caracterização das formas da Bacia Hidrográfica, o principal método selecionado foi a análise morfométrica. Este método adquiriu importância no mundo, desde a publicação do trabalho de Horton (1945) e impulsionado no Brasil com a revisão metodológica de Christofolleti (1969).

Existem atualmente cerca de 40 parâmetros morfométricos já estudados que definem os tipos de redes, padrões ou sistemas de drenagem (ROCHA, 1991), dentre os quais foram selecionados os parâmetros mais 
afinados com a teoria sistêmica: a formação dos fluxos, as relações com os demais elementos do sistema e a propensão a formação de ameaças com base nos trabalhos de Christofoletti (1969; 1980); Rocha (1991), Beltrame (1994) e Coutinho (2013), calculados a partir da metodologia descrita por esses autores, apresentadas na Tabela 1:

Tabela 1 - Principais parâmetros morfométricos calculados.

\begin{tabular}{|l|c|c|}
\multicolumn{1}{c}{ Parâmetro } & Símbolo & Equação \\
\hline Área & $A$ & - \\
\hline Perímetro & $P$ & - \\
\hline Comprimento do eixo principal & $L$ & - \\
\hline Coeficiente de compacidade & $K c$ & $K c=0,28 P / \sqrt{A}$ \\
\hline Índice de Circularidade & $I C$ & $I C=4 \pi A / P^{\wedge} 2$ \\
\hline Fator Forma & $K f$ & $K f=A / L^{\wedge} 2$ \\
\hline Razão de Elongação & $R e$ & $R e=\left(1,128 . A^{\wedge} 0,5\right) / L$ \\
\hline Índice de Sinuosidade & $I s$ & $I s=100(L c-e V) / L c$ \\
\hline Densidade de Drenagem & $D d$ & $\mathrm{Dd}=\mathrm{C} / \mathrm{A}$ \\
\hline Declividade Média & $D m$ & $\mathrm{Dm}=(\mathrm{Cn} \cdot \Delta \mathrm{h}) / \mathrm{A}$ \\
\hline
\end{tabular}

*Lc e Dv são respectivamente o comprimento vetorial e distancia vetorial entre os extremos do canal principal; C é o comprimento total dos canais da BHRS; $\Sigma$ cn é o somatório dos comprimentos de todas as curvas de nível da BHRS, $\Delta \mathrm{h}$ é a equidistância entre essas curvas de nível.

\section{RESULTADOS E DISCUSSÕES}

A BHRS possui, entre a foz e a cabeceira de seu rio principal, um desnível total de pouco mais de 350 metros. Considerando toda área da bacia, há pontos isolados com cotas superiores aos 500 metros, vestígios de dissecações antigas do relevo, mas apesar disso, a maior parte da cabeceira encontra-se entre as cotas de 300 e 330 metros, altitudes médias dos divisores de água dessa área.

O perfil topográfico do rio Subaúma e a setorização da BHRS podem ser visualizados respectivamente nas Figura 2 e 3:

Figura 2 - Perfil topográfico da Bacia Hidrográfica do Rio Subaúma - BA.

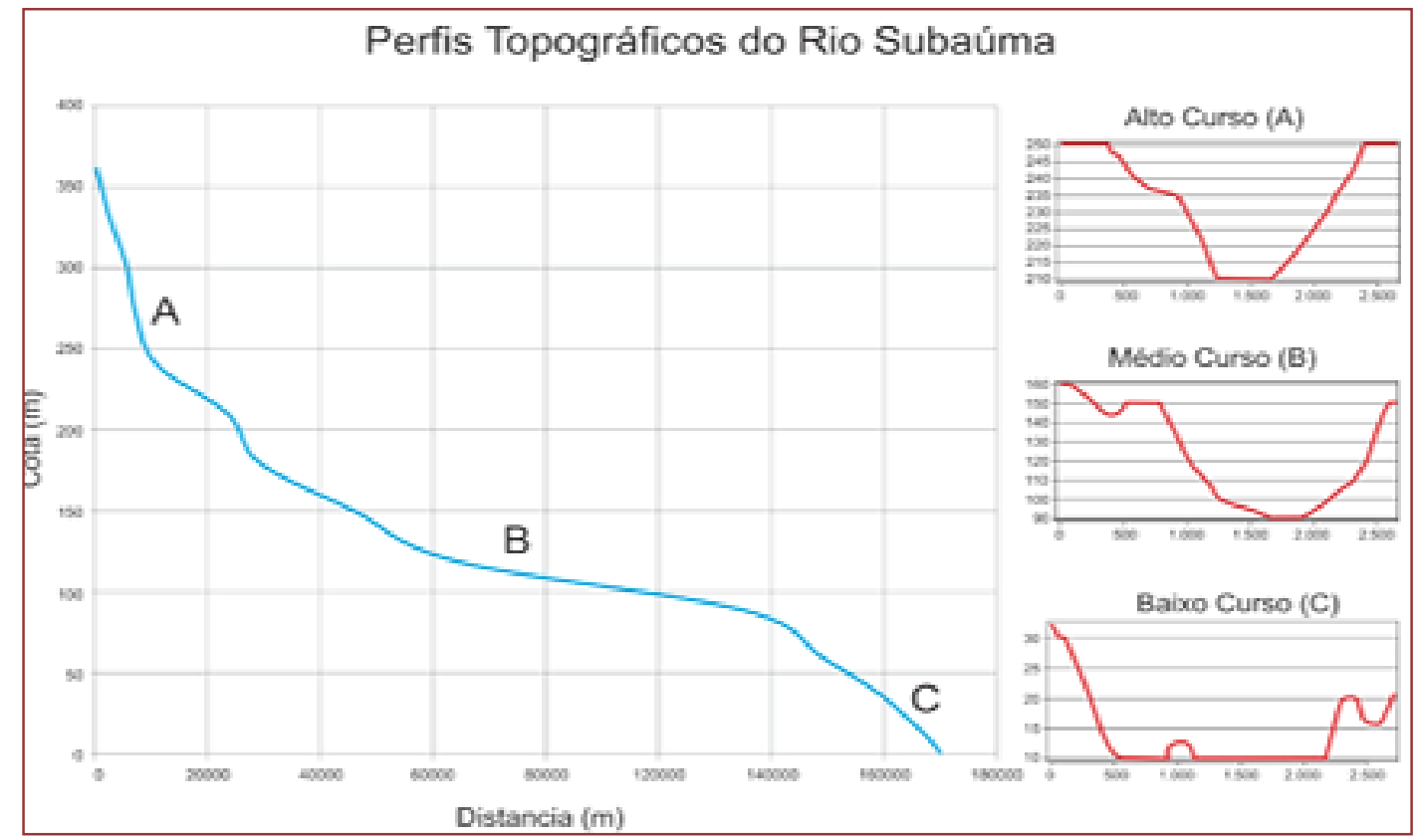


Figura 3 - Setoriação da Bacia Hidrográfica do Rio Subaúma - BA.

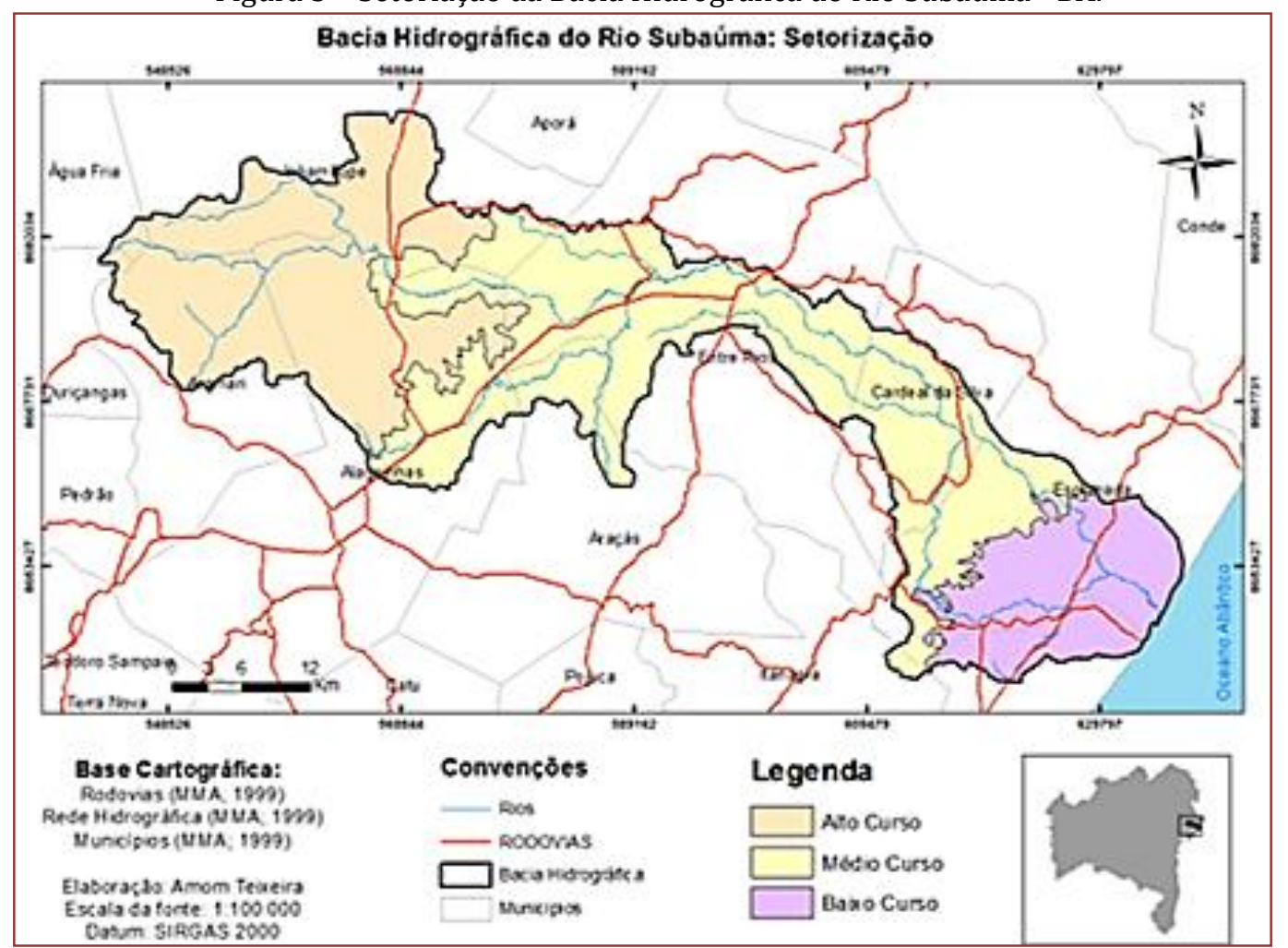

O perfil longitudinal é o resultado, segundo Davis (1954 apud CHRISTOFOLETTI, 1980), de um conjunto de variáveis tais como débito, carga detrítica fornecida ao canal, granulometria dos sedimentos, resistência ao fluxo, velocidade da água, largura, profundidade e declividade do canal. 0 recorte do perfil topográfico do rio Subaúma permitiu a visualização e identificação dos pontos de ruptura de declive (knick points), das modificações no relevo da bacia e dos estoques de massa disponíveis para erosão que foram utilizados para setorização.

No setor A, Alto Curso, que vai da principal nascente até o cruzamento com a cota de $190 \mathrm{~m}$, o rio corre sobre uma rampa mais íngreme e ligeiramente côncava. A ação da curvatura vertical do relevo pressiona o escoamento superficial e a erosão nas áreas mais altas da concavidade do perfil. Nas partes mais baixas do terreno deste setor, há o equilíbrio entre a infiltração e o escoamento superficial conforme diminuem as declividades e há a redistribuição da energia cinética.

Correndo principalmente sobre terrenos sedimentares, este trecho possui de modo geral os relevos mais íngremes da bacia, já bastante dissecados pela erosão fluvial e pela gravidade que atua pela busca do estado de equilíbrio do meio, conforme há uma contínua retirada de material sedimentar. Os vales fluviais tendem a ser menos largos, com vertentes mais declivosas que os demais setores, formando geralmente um "V" com fundo chato modelado por trechos de maior velocidade dos cursos fluviais.

No setor B, Médio Curso, há um relativo equilíbrio entre a erosão e a deposição de sedimentos, fazendo com que a curvatura vertical do relevo varie entre a concavidade nas áreas mais altas do setor e a declividade sub-horizontal nas partes mais baixas. A ação da erosão fluvial tende a ser compensada pela deposição de sedimentos carreados do alto curso do rio. 0 equilíbrio entre deposição, erosão e a menor quantidade de energia cinética das águas formam vales fluviais mais largos que os do setor mais alto e de vertentes côncavas, o que lhe dá a aparência de "U".

A estabilidade do meio varia bastante de acordo com a posição no relevo, mas em geral, as declividades menores geram uma maior tendência a estabilidade do que no alto curso do rio Subaúma. No setor C, Baixo Curso, o perfil fluvial assume uma disposição convexa, formada pela contínua deposição de sedimentos provenientes das áreas mais altas da bacia. Nas áreas mais rebaixadas, os rios vão perdendo sua competência em transportar sedimentos, proporcionando a formação das planícies através de processos deposicionais e de sedimentação. Portanto, evidencia-se neste ponto da bacia o alargamento do vale com planície fluvial mais extensas, quando comparado aos demais setores da bacia. 
Com uma área de $1.555 \mathrm{~km}^{2}$ e um perímetro de $327,5 \mathrm{~km}$, a BHRS pode ser considerada uma Bacia Hidrográfica de grande porte, segundo divisão realizada por Ponce (1989 apud CAMPOS, 2009). Tal característica, aliada ao eixo de cerca de $97 \mathrm{~km}$, no sentido leste-oeste, implica na distribuição têmporoespacial heterogênea das precipitações. Os principais atributos morfométricos da BHRS e dos setores podem ser vistos na sinopse da Tabela 2 .

Tabela 2 - Sinopse dos parâmetro morfométricos da BHRS

\begin{tabular}{|l|c|}
\hline \multicolumn{1}{|c|}{ Parâmetros Morfométricos } & Bacia Hidrográfica \\
\hline Área $\left(\mathrm{km}^{2}\right)$ & 1555,45 \\
\hline Perímetro $(\mathrm{km})$ & 327,49 \\
\hline Maior Eixo $(\mathrm{km})$ & 97,69 \\
\hline Índice de Compacidade & 2,33 \\
\hline Fator Forma & 0,16 \\
\hline Razão de Elongação & 0,46 \\
\hline Índice de Circularidade & 0,18 \\
\hline Índice de Sinuosidade $(\%)$ & 32,82 \\
\hline Comprimento da Vazão Superficial $(\mathrm{km})$ & 3728,45 \\
\hline Densidade de Drenagem $\left(\mathrm{km} / \mathrm{km}^{2}\right)$ & 2,39 \\
\hline
\end{tabular}

A BHRS é uma bacia exorreíca, segundo classificação explicitada em Christofolleti (1980). O padrão de drenagem predominante da BHRS é o dendrítico, com 3728,4 km de canais organizados em sete ordens, segundo a classificação de Strahler (1957), características que, segundo Summerfield (1991), geralmente indicam gênese com fraco controle estrutural das rochas.

A relação entre o comprimento dos canais e a área total da bacia teve como resultado, a densidade de drenagem de $2,39 \mathrm{~km}$ de canais por cada $\mathrm{km}^{2}$, valor compatível com bacias de baixa densidade de drenagem, segundo a classificação realizada por Christofoletti (1969), e que indica, segundo Rocha (1991), a presença de relevos suaves e/ou solos e rochas permeáveis. Essa indicação é corroborada por Christofoletti (1980), que afirma que nas rochas onde há maior dificuldade de infiltração, há também condições melhores para o escoamento superficial, gerando possibilidades para a esculturação de canais e em consequência formação de densidade de drenagem elevadas.

Dessa forma, a baixa densidade de drenagem é indicativo de tendências altas de infiltração e baixas de escoamento superficial, segundo a classificação explicitada Nardini et al. (2013), realizada a partir de uma revisão das contribuições de Horton (1945), Strahler (1957) e França (1968 apud NARDINI et al., 2013).

Do ponto de vista da dinâmica ambiental, a baixa densidade de drenagem pode significar maior estabilidade da paisagem, já que segundo Rocha (1991), os processos erosivos começam nas ravinas. Desse modo, quanto menor o valor da densidade de drenagem menor será o risco de erosão.

0 valor adimensional do Índice de Compacidade do Rio Subaúma $(2,33)$ indica uma bacia pouco circular, o que lhe traz baixo grau de vulnerabilidade à inundações. A fraca tendência a inundações do ponto de vista morfométrico é corroborada pelos valores do Fator Forma $(0,16)$, do Índice de Circularidade $(0,46)$, e Razão de elongação $(0,18)$, que indicam uma bacia com forma elongada e, portanto menos sujeita a enchentes.

Esses índices estão diretamente relacionados ao escoamento da Bacia Hidrográfica: bacias mais circulares tendem a receber a precipitação de maneira mais uniforme do que bacias retangulares ou alongadas, além disso em bacias circulares a chegada da água precipitada ao canal principal (tempo de concentração), tende a ser menos distribuída temporalmente, aumentando o risco de enchentes.

0 baixo risco a inundação da BHRS, sob o ponto de vista morfométrico, também pode ser visto no índice de sinuosidade que tem o valor de 32,8\% (canal divagante), refletindo velocidades não muito altas de escoamento, que por sua vez se refletem na baixa possibilidade de enchentes a jusante da precipitação na bacia (MANSIKKANIEMI, 1970).

\section{CONSIDERAÇÕES FINAIS}

A partir do uso de técnicas de geoprocessamento foi possível produzir uma análise das características morfometricas da BHRS, indicando uma bacia hidrográfica com baixo risco a inundação, tendências altas de infiltração em relação ao escoamento superficial. 
As características morfométricas aliadas à disposição do relevo da maior parte da bacia, especialmente do médio e baixo curso, com superfícies quase planas, sub-horizontais com ligeiro declive em direção à costa, cortadas por canais de dissecação, de constituição geológica, predominantemente sedimentar, associados as características pluviométricas, com precipitações bem distribuídas ao longo do ano, favorecem os fluxos lentos da água, propiciando a infiltração das precipitações d'água através de solos porosos até as camadas do subsolo, onde formam aquíferos e lençóis freáticos que conduzirão a água subterrânea até os corpos d'agua superficiais.

\section{REFERÊNCIAS}

[1] Beltrame, A.V. (1994). Diagnóstico do Meio Físico de Bacias Hidrográficas: Modelo e Aplicação. Florianopolis: Editora da UFSC. 111p.

[2] CAMPOS, J.N.B. (2009). Lições em Modelos e Simulação Hidrológica. Fortaleza, ASTEF. 166p.

[3] CHRISTOFOLETTI, A. (1980). Geomorfologia. Edgard Blucher. São Paulo. 188p.

[4] COLLARES, E.G. (2000). Avaliação de alterações em redes de drenagem de microbacias como subsídio ao zoneamento geoambiental de bacias hidrográficas: aplicação na bacia hidrográfica do rio Capivari-SP. Tese (Doutorado em Geotecnia). Universidade de São Paulo - USP. 194f.

[5] COUTINHO, L.M. (2013). Influência de padrões morfométricos sobre as ocorrências de inundações na bacia do Córrego Cobiça, Cachoeiro de Itapemirim-ES. Anais XVI Simpósio Brasileiro de Sensoriamento Remoto - SBSR, Foz do Iguaçu, PR, Brasil, p.5769-5776.

[6] FREITAS, R.O. (1952). Textura de drenagem e sua aplicação geomorfológica. Boletim Paulista de Geografia. n.11, p.53-57.

[7] GANDOLFI, N. (1971). Investigações sedimentológicas, morfométricas e físico-químicas nas bacias do MogiGuaçu, do Ribeira de Iguape e do Peixe. Boletim de Geologia - EESC/USP, v.14, p.1-108.

[8] HORTON, R.E. (1945). Erosinal development of streams their drainage basins: hidrophysical approach to quantitative morphology. Bulletin of the Geological Society of America, Colorado (EUA), v.56, p.275 - 370.

[9] MANSIKKANIEMI, H. (1970). The sinuosity of rivers in northern Finland. Publicationes Instituti Geographici Universitatis Turkuensis, n.52, p.16-32.

[10] MOSCA, A.A.O. (2003). Caracterização Hidrológica de Duas Microbacias Visando a Identificação de Indicadores Hidrológicos para o Monitoramento Ambiental do Manejo de Florestas Plantadas. Dissertação (Mestrado em Recursos Florestais) - Universidade de São Paulo - USP, Piracicaba - SP, $96 \mathrm{f}$.

[11] NARDINI, R.L.; POLLO, R.A.; CAMPOS, S.; BARROS, Z.X.; CARDOSO, L.G.; GOMES, L.N.; Análise Morfométrica e Simulação das Áreas de Preservação Permanente de uma Bacia Hidrográfica. Irriga, Botucatu, v. 18, n. 2013, 4p.

[12] ROCHA, J.S.M. (1991). Manual de Manejo Integrado de Bacias Hidrográficas. Santa Maria: UFSA, 2ª ed, 181p.

[13] STRAHLER, A. N. (1957). Quantitative analyses of watershed geomorphology. Transactions of American Geophysical. v.38, n.6, p. 913-920.

[14] SUMMERFIELD, M.A. (1991). Global Geomorphology: an introduction of the study of land forms. Essex, Longman Scientific \&Technical. 537p.

[15] TEODORO, V.L.I.; TEXEIRA, D.; COSTA, D.J.L.; FULLER,B.B. (2007). 0 conceito de bacia hidrográfica e a importância da caracterização morfométrica para o entendimento da dinâmica ambiental local. Revista Uniara, n.20.

[16] VILELLA, S.M; MATTOS, A. (1975). Hidrologia Aplicada. São Paulo: Mcgraw-Hill do Brasil. 245p. 


\section{Capítulo 2}

Meio ambiente, civilização e espaço geográfico. Ecovilas genuínas e o modo de ser e habitar zeloso

\section{Severiano José dos Santos Júnior}

\section{Catherine Prost}

\section{Roberto Bartholo}

Resumo: Com base no utilitarismo tecnocientífico, na massificação industrial e expansão do mercado, o ethos (modo de ser e habitar) moderno impulsionou quebras de fronteiras jamais imaginadas. Do ponto de vista do espaço geográfico, a crise ambiental é fruto da pilhagem em larga escala de recursos e dos sistemas naturais. Porém, diante da potencial exaustão, cresce a percepção de que os sistemas socioambientais não poderão suportar tal pressão por muito tempo. Com base na sustentabilidade, holismo, comunitarismo e em uma visão cósmica da Terra, o ethos zeloso é concebido como fundamento de lugares zelosos, socialmente justos e de comunhão entre humanos e não humanos. Ainda que em escala local, com base no cuidado, propõe-se que as ecovilas genuínas são espaços de experimentação de mudanças paradigmáticas técnicas e valorativas nas relações entre assentamentos humanos e ecossistemas.

Palavras-chave: crise civilizatória e ambiental, ethos zeloso, ecovilas genuínas 


\section{INTRODUÇÃO}

Este trabalho objetiva refletir sobre a crise ambiental contemporânea, considerando que a degradação do meio ambiente está diretamente relacionada às discrepâncias do modelo socioespacial e civilizatório vigente. Não se pode pensar os impactos negativos no ar, nas águas, no solo, no regime climático e nas condições de vida das populações que vivem na e do meio ambiente sem uma reversão no modo exploratório como as sociedades desenvolvimentistas em geral e capitalistas em particular ocupam o espaço. Nem tampouco se admite uma interrupção irreversível deste processo sem uma profunda crítica aos fundamentos civilizatórios modernos de base na racionalidade técnica-instrumental, na economia produtivista-consumista capitalista e na cosmovisão materialista e laica. Fruto do curso de doutoramento no PosGeo-UFBA, este trabalho discute mais diretamente este segundo aspecto. Para isto, analisa o caso das ecovilas genuínas com base no ethos zeloso - modo, material e imaterial, de ser, morar e ocupar a terra de caráter dialógico, sustentável e emancipado.

\section{HYBRIS CIVILIZATÓRIA, DESMESURA E A INSACIABILIDADE COMO MODO DE SER (E DE HABITAR) MODERNO}

Após a Idade Média, em países do Ocidente Europeu, o antropocentrismo, laico e autônomo, foi se tornando medida civilizatória que liberou o humano para produzir o espaço a partir da razão pragmática e utilitária (BARTHOLO, 1986). Fundamentado no racionalismo da tecnociência, na massificação exploradora industrial e expansão progressiva do mercado, tal projeto delineou um ethos (modo de ser e habitar) utilitário como fundamento das instituições políticas, sociais e econômicas. Estas operações impossibilitaram o vínculo ontológico entre cultura e Natureza na medida em que institucionaliza o instrumental e o funcional como substitutos à cosmovisão mágico-simbólica dos povos arcaicos e tradicionais. Dos fenômenos, elementos e seres presentes e constituintes dos reinos mineral, vegetal e animal é tirada a anima, restando-lhes a condição de recurso. Nessa perspectiva, a natureza apossada e dominada é transformada em produto, isto é, fonte de renda econômica (POLANYI, 2000), um bem-objeto a ser processado e vendido nos diversos estratos e formas de configuração do mercado.

O ethos moderno se mostra como habitar explorador do mundo e torna-se presente no espaço planetário pela engenhosidade da tecnociência (HEIDEGGER, 2006; BARTHOLO, 1986). Numa casa sem mistérios, a subordinação da moral e da ética ao antropocentrismo e ao progresso material é uma ocorrência nova na história humana. Para Unger (1991) isto nos levou a uma crise civilizacional, pois “(...) o que está em crise é toda a trama de relações mediante a qual os homens tecem sua inserção no real" (UNGER, 1991, p. 64). Morin e Kern (1994) referem-se a este processo como a "ocidentalização do mundo", a qual se transfigura na “(...) idade de ferro planetária, na qual ainda nos encontramos” (MORIN; KERN, 1994, p. 17). Igualmente, a extensão desse processo se mostra pela crescente dessacralização do espaço geográfico, natural e humano: “(...) o mundo profano na sua totalidade, o Cosmo totalmente dessacralizado, é uma descoberta recente na história do espírito humano” (ELIADE, 1980, p.25). Esta cosmovisão adentrará o tecido social e implicará a quebra espacial dos limites entre sociedades e ecossistemas naturais.

Na tradição antiga, por medo, fé ou sabedoria, preceitos e morais religiosas conformavam o humano a um espaço seguro em meio à inexorabilidade última da realidade. Para a tradição grega, a vontade de violação desses princípios é parte inerente à natureza humana, pois, é da condição humana a aptidão ao excesso, à hybris $^{1}$. Por isto deve ser evitada sob pena da própria condenação (JAEGER, 1989). Ao mistério incomensurável da Natureza e do Cosmo é solicitado comedimento, pois, somente em atitude de contenção o humano encontrará seu lugar na ordem universal de todas as coisas. Diante de algo que não pode alcançar por capacidades e meios próprios, o humano deve se ajustar a esta realidade que lhe transcende e evocar o pertencimento e a precaução como modos de refreamento da desmesura. Porém, o modelo civilizatório moderno rompe este trato é se torna o único a fazer da hybris seu modo de ser e de habitar. Unger (1991) assinala:

(...) Enquanto outras sociedades fizeram do eixo de sua cultura a elaboração de técnicas para controlar essa tendência, a nossa fez da hybris sua virtude máxima. 0 projeto de dominação de tudo o que existe, a ruptura da dimensão cosmo-polita do homem, a busca de mais e mais poder sobre a natureza, sobre

1 Hybris é um conceito grego que pode significar, simultaneamente, "destino", "parte", "lote" e "porção". Aqui, ao evocar o caráter niilista da ética moderna, usa-se hybris tendo em vista seu sentido moral de limite encontrado na tragédia grega (JAEGER, 1989). Porém, quando se refere ao caráter híbrido das culturas, identidades, espaços, etc., refere-se às misturas, à imbricação de diferentes porções para formar um novo destino. 
tudo e sobre todos, o antropocentrismo formam o eixo em torno do qual, enquanto civilização gravitamos (UNGER, 1991, p. 40).

Nesta perspectiva, o ethos moderno nunca se considera pronto, em função da permanente insaciabilidade por novidades e por acreditar que limites e horizontes existem apenas para serem ultrapassados. Em torno da desmesura, a civilização moderna se reproduz pelas conquistas sobre as dimensões do espírito e pela imposição material tecnocientífica sobre povos e territórios. Na perspectiva do espaço geográfico, 0 modo de ser inaugurado na modernidade impulsionou quebras de fronteiras e ações que cobriram todas as regiões do Planeta de artefatos jamais imaginados por civilizações anteriores.

\subsection{A CONQUISTA DO MUNDO E DA NATUREZA: ESPAÇO GEOGRÁFICO E A CRISE AMBIENTAL CONTEMPORÂNEA}

Na contemporaneidade, regido pelo capital e na forma de motor único, o projeto civilizatório moderno estabeleceu seu poder sobre o mundo ao integrar redes técnicas, econômicas e culturais globais, naquilo que Santos $(1996,2000)$ concebe como o meio técnico-científico-informacional. Ao articular espacialmente conjuntos técnicos e de informação, unifica lugares e oferece base para a expansão das forças modernizadoras por todas as regiões. Ao originar uma economia de crescente produção de bens e valores para o acúmulo, o motor único capitalista oferece-se como força de inigualável ambivalência: integra as sociedades e cria fragmentação e exclusão de territórios e populações (HAESBAERT, 1995). Por outro lado, feita objeto pela laicidade científica, a natureza é lançada aos delírios do mercado, expropriada pela técnica e transformada em matéria-prima pela indústria. Daí decorre a naturalização do excesso como medida da exploração dos recursos naturais, em meio ao crescimento de um mundo em convulsão.

Em seus aspectos geohistóricos, a crise ambiental é fruto da pilhagem de recursos, do uso abusivo dos sistemas naturais (água, ar, solo, recursos minerais e vegetais) e da deposição de rejeitos dos sistemas produtivos e de consumo em larga escala. Os dados apresentados na mídia, em tratados científicos, informativos governamentais e não governamentais, têm atestado estes impactos. Mesmo nos prognósticos mais brandos, o recente debate em torno das mudanças climáticas não deixa qualquer dúvida quanto aos fortes impactos negativos que as sociedades industriais têm imposto ao meio (IPCC, 2014). Por outro lado, com base nas histórias dos lugares e das pessoas, narrações sobre a degradação ambiental são cada vez mais comuns: rios puros se transformando em esgotos a céu aberto; nascentes que secaram; matas destruídas para dar lugar a projetos agrícolas, industriais ou urbanos; praias e mares sujos; aumento da poluição sonora, do ar ou visual; desaparecimento de espécies animais; mudanças nos regimes das chuvas e dos períodos de estiagem. Enfim, os danos causados pela sociedade global capitalista têm sido percebidos por diferentes meios, bem como a contaminação do ambiente têm piorado a qualidade de vida dos agrupamentos humanos.

Como dito, a crise se amplia para além dos aspectos puramente ambiental e ecológico e tem levado muitos estudiosos a assinalar um limite na maneira de disseminação da civilização ocidental pelo mundo (UNGER, 1991; MORIN; KERN, 1994; LEFF, 2000). As crises crescem com o aumento da produção, do consumo e com o desenvolvimento dos países. As intervenções produtivas, que até certo momento eram vistas como ampliação de riqueza, começam também a ser percebidas como problemas. Gonçalves (2004) expõe: “(...) afinal, até os anos 1960, a dominação da natureza, não era uma questão e, sim, uma solução - o progresso. É a partir deste período que intervém explicitamente a questão ambiental” (GONÇALVES, 2004, p. 23).

Desse modo, a consciência da desmesura tem catalisado novas tomadas de rumo nas relações entre sociedade e Natureza. Diante da potencial exaustão de recursos naturais, a crise pode levar à fragilização (ou mesmo morte) dos atuais modelos socioeconômicos, ou, de forma ainda mais radical, do próprio sentido de humanidade (UNGER, 1991). Há quase meio século, muita energia, tempo e dinheiro têm sido mobilizados na busca por saídas para os impasses (PRESTRE, 2000). Apesar da percepção de urgência, há ainda incontornável negligência por parte de instituições sociopolíticas em posição de hegemonia. Nesse contexto, cresce a disputa em torno de conceitos e diretrizes políticas para se debelar a crise. De um lado, saídas em torno do mercado verde, do desenvolvimento sustentável são consideradas escamoteadoras da crise e do papel de seus atores hegemônicos (RODRIGUES, 2005). Em outras, a crise ecológica e a sustentabilidade assinalam para proposições horizontais, emancipadas e inclusivas (LEFF, 2000).

A crise ambiental torna-se assim fator de risco civilizatório e planetário e solicita juízos e decisões para a sustentação dos sistemas socioambiental. Diante da depredação do meio cresce a percepção de que tanto os ecossistemas quanto os sistemas sociais não poderão suportar tal pressão por muito tempo. Os impactos são diferenciados; vêm de todos os lados, apontando sempre na direção da, ou melhor, contra a 
Natureza. Na perspectiva do ethos (e da crítica ética), a crise ecológica está diretamente vinculada à dissociação moderna agenciada pelos mecanismos racionais e mercadológicos. É diante da desmesura, em especial de sua capacidade de criar fraturas entre o simbólico e o lógico, o objeto e o sujeito, o material e o imaterial, que o entendimento da essência e da origem da grande degradação dos sistemas naturais impingida por sociedades reificadoras pode acontecer. Por outro lado, abre a possibilidade para o reconhecimento de pessoas e grupos envolvidos em ações horizontais reativas e propositivas a essa questão.

\subsection{ETHOS, ESPAÇO GEOGRÁFICO E A ONTOLOGIA ZELOSA COMO CONTRAPOSIÇÃO À CRISE CIVILIZATÓRIA E AMBIENTAL MODERNA}

Na construção do espaço geográfico planetário, as coisas, ideias e ações ganham significado na política e na cultura. Bartholo e Delamaro (2002, p.13) afirmam que as "(...) estruturas normativas transcendentes à ação do sujeito" tem sido pensada pela tradição filosófica "(...) com o desígnio genérico de o ethos, (...) as expressões dos grandes domínios simbólicos do mundo e da cultura (linguagem, mito, artes, saberes)”. É o lugar da morada e o modo do habitar. Para Boff (1999):

(...) Ethos em seu sentido originário grego significa a toca do animal ou casa humana, (...) porção do mundo que reservamos para organizar, cuidar e fazer o nosso habitat. (...) Esse ethos (modelação da casa humana) ganhará corpo em morais concretas (valores, atitudes, comportamentos práticos) consoantes às várias tradições culturais e espirituais (BOFF, 1999, p. 27).

De acordo com Boff (1999, p.195), “(...) o ethos constrói pessoal e socialmente o habitat humano”. É por meio do ethos que pessoas e coletivos se autorealizam ao evocar o dever-ser humano a partir da relação e convívio com outros seres, em aprendizagem com o meio - para os gregos antigos, a physis, que incluía o visível e o invisível, o humano e o não humano, o transcendente e o terreno. Nessa perspectiva, Vaz (1988, p.13) assinala que "(...) o ethos é a casa do homem. O homem habita sobre a terra acolhendo-se ao processo seguro do ethos". Essa casa imaterial, “(...) lugar de estada permanente e habitual, (...) não é dada ao homem, mas por ele construída, ou incessantemente reconstruída”. No ethos, por meio do hábito voltado às virtudes, mantem sua conexão com a presença cósmica da physis - definida mais tarde pelos latinos como natureza. Para Vaz (1988, p.11), há um vínculo ontológico entre ethos e physis, pois o ethos é “(...) a transcrição da physis na peculiaridade da práxis ou da ação humana e das estruturas históricosociais que dela resultam". Este vínculo permite, assim, a integração dinâmica e complexa do humano à fisicalidade do Planeta e, do ponto de vista epistemológico, gera uma abordagem socioespacial que vincula materialidade histórica dos territórios às cosmovisões de pertencimento locais, regionais e universais.

O ethos é assim um habitat relacional e valorativo que se adere ao mundo como habitus, modo de ser que tende à repetição, mas que caracteriza fisicamente a maneira própria como o humano habita e é. Disto decorre a importância atual da reflexão ética e ontológica sobre o conceito de ethos. Boff (2008) afirma que:

(...) Como nunca antes na história do pensamento, a palavra grega ethos assume seu pleno sentido. Para os gregos, ethos significava fundamentalmente a morada humana, não em sua materialidade, mas em seu sentido existencial como aquela porção da natureza (physis) que reservamos para nós, a organizamos e cuidamos de tal modo que se transforma em nosso habitat, o lugar onde "nos sentimos em casa", protegidos e vivendo em harmonia com todos os que nela habitam, com os vizinhos e com a natureza circundante (BOFF, 2008, p. 166).

O ethos pertence ao humano no encontro entre sociedade e Natureza. Ao fazer da habitação na Terra seu modo de ser no mundo, a Terra lhe corresponde o afeto e o apelo (BOFF, 1999), diante do qual o humano se sente compelido a fazer de sua morada uma casa vicejante. Como mostra Boff (2008), o ethos é a matriz ontológica e ética humana que transforma uma parte da fisicalidade do Planeta em um lugar, um espaço pleno de identidade e significado (TUAN, 1983). Coletivamente, o ethos é quem permite o crescimento das raízes na história e cria sua geograficidade - ligação concreta do humano à Terra. Por meio da ocupação e produção do espaço, "(...) como modo de sua existência e de seu destino" (DARDEL, 2011, pp. 2-3), o ethos cresce unificando a materialidade produtiva da Terra à criação imaterial do mundo. Diante da crescente desmesura na produção do meio técnico-científico-informacional atual, novos modos de integração entre a práxis humana e o meio necessitam serem buscados. Neste trabalho, propõe-se um modo de ser e habitar 
no qual o cuidado é medida ética e ontológica aos jogos políticos de espacialização das sociedades (SANTOS JR., 2015).

A partir de Heidegger (1988), Boff (1999) vê-se o zelo, cuidado, como condição ontológica própria ao modo de ser e habitar humano. Igualmente, diante da crise civilizatória atual, o ethos assume seu caráter ético de limite epistemológico e político às ações humanas entre si e com o Planeta. A palavra “(...) zeloso (...) pode ser sinônimo de cuidadoso, diligente ou ciumento. Com origem no grego zélos, esta palavra também descrevia um estado de dedicação ardente e de cuidado de alguém em relação a outra pessoa". Portanto, zelo e zeloso aparecem como cuidado enquanto atenção diligente e meticulosa, como atitude de disposição e dedicação. Nesse sentido, zelo envolve tanto o tempo prático da dedicação atenciosa quanto o afeto, o ardor e a empatia (pathos) que vincula dialogicamente dois seres sob o ato do cuidado. Igualmente, o cuidado sugere o lugar existencial no qual o cuidado (cura) acontece enquanto condição ontológica fundante. 0 ser que cuida se atenta para que o cuidado cuide daquilo a ser curado, enquanto cogita, medita, coloca atenção naquilo que no outro já se deu, desde a origem, como o já curado.

Nessa perspectiva, com base na sustentabilidade, holismo, comunitarismo e em uma visão cósmica da Terra/terra, o ethos zeloso é concebido como fundamento para que as ecovilas se espacializem como lugares zelosos, isto é, lugares socialmente justos de convívio e comunhão entre humanos e não humanos, que se comportam como provocadores de mudanças paradigmáticas técnicas e valorativas nas relações entre assentamentos humanos e ecossistemas. Tais circunstâncias se tornam favoráveis à leitura das ecovilas genuínas a partir de um campo de mudanças paradigmáticas (no contexto de fronteiras sociocivilizatórias) que solicitam novas estruturas sociais e novas finalidades civilizatórias. Presente em assentamentos humanos de baixo impacto e de vivência de sistemas técnicos e sócio-valorativos horizontais e ecológicos (primeiramente em comunidades e povos tradicionais), o ethos zeloso das ecovilas genuínas surge como proposta de construção de modo de ser e de habitar o Planeta enquanto elo fronteiriço de enraizamento na terra como solo e lugar, a partir do reconhecimento da intricada rede de relação que envolve os sistemas sociais e naturais.

\subsection{ECOVILAS GENUÍNAS, SISTEMAS TÉCNICOS SUSTENTÁVEIS E HABITAR ZELOSO}

Surgido como conceito e movimento na década de 1990, o modelo das ecovilas aparece como assentamento de pessoas que se juntam para viver estilo de vida simples a partir de relações orgânicas e de baixo impacto com os ecossistemas e contextos socioculturais locais (TRAINER, 2000; BANG, 2005; DAWSON, 2006). Influenciados por legados tradicionais, contraculturais e intencionais, são grupos que se propõem a realizar experimentações de novos arranjos espaço-temporais em situações de fronteira e confrontos paradigmáticos Escolhem e recomendam mudanças na atual dissociação sociedade-natureza com base numa visão emancipada da sustentabilidade, em novos sistemas técnicos e valorativos híbridos e em modos de viver bem e simplesmente. As ecovilas se tornam, assim, laboratórios de experimentação e difusão de práticas holísticas de zelo para com o meio socioambiental, tais como: permacultura, bioconstrução, agroecologia, sistemas agroflorestais e de recomposição ambiental, sistemas ecológicos de tratamento de dejetos, energia renováveis, paisagismo integrativo, dentre outros.

O ethos zeloso tecido nas ecovilas genuína surge como composição híbrida de valores e técnicas a partir de diversas matrizes culturais e de conhecimento e assinala para uma percepção abrangente e inclusiva do ser humano com os sistemas naturais. Wight (2008) expõe algumas dessas questões ao analisar o entendimento que possuem os membros de ecovilas com respeito à Natureza. A visão de natureza dos membros de ecovilas é distinta daquelas encontradas na maioria das escolas de pensamento, pois, estes não veem diferença entre eles mesmos, a biosfera maior (todas as entidades viventes) ou outros processos de criação universal. Eles acreditam que "nós somos a natureza" (WIGHT, 2008, p. 28), pois, o cultural e o natural se juntam ao compartilharem elementos materiais, subjetivos e espirituais inclusos em um todo maior.

Para Wight (2008), a expressão "nós somos a natureza", repetida inúmeras vezes por seus entrevistados, mostra que todos os seres estão indissociavelmente interligados a uma realidade maior, a partir de uma visão que unifica a temporalidade tradicional de base espiritual com diversos elementos das fronteiras paradigmáticas da ciência contemporânea. Nessa perspectiva, a integração entre humanidade e natureza se fundamenta em uma história cosmológica evolutiva na qual os membros de ecovilas genuínas se veem participando cotidianamente. Geografia humana se une ao destino da Terra em uma teleologia sociopolítica e cósmica. 0 tratamento zeloso aos sistemas naturais por meio das tecnologias sustentáveis e o estilo de vida simples e solidário reforçam o senso dialógico de pertencimento à terra e interpõem um limite ético às ações. 
Essa proposição é encontrada em Bang (2005). Para ele, na escolha do local para implantação de uma ecovila, é necessário certa sensibilidade espiritual, a despeito da resistência de alguns planejadores. Bang (2005) argumenta que isto tem importante função na construção da "alma do grupo", já que, nelas, "(...) tudo tem um aspecto espiritual, incluindo o lugar e a construção" (BANG, 2005, p. 97). A dinâmica dos grupos apresenta aspectos sutis, espirituais e sociais que também devem ser aplicados no planejamento mais geral de um projeto de ecovila, junto aos demais aspectos trabalhados (estruturas físicas, finanças e regulamentações, cultivo e paisagismo). É necessário, porém, se ultrapassar limites postos pelo pensamento racional e pelos padrões técnicos estabelecidos socialmente. Para Bang (2005), é na abertura sensível dos planejadores à experiência vivida, à intuição e à criatividade que um possível diálogo com o espírito do lugar poderá acontecer.

$\mathrm{Na}$ abertura à sensibilidade, à intuição, à atenção, as áreas de uma ecovila genuína se tornam fendas fractais do processo integrativo de criação de um lugar consciente do imanente e aberto ao transcendente. Materializadas nas estruturas que formam o organismo comunitário, as construções sociotécnicas do espaço geográfico devem se colocar para além do mercado e agentes hegemônicos. As ecovilas genuínas tendem assim a funcionar como mandalas, na qual o todo se inscreve em cada parte e as partes no todo. As manifestações artístico-culturais, as atividades educativas, produção de alimentos e nutrição, os procedimentos ligados à saúde, paisagismo e o zelo ao ambiente passam a ser vistos como processo de integração do indivíduo a si mesmo, à sua comunidade, ao seu entorno, ao mundo e à Terra. Para os antigos isto é visto como aliança entre macrocosmo e microcosmo, intercâmbio entre social e espiritual, encontro da polis com a physis e o cosmos.

Nas ecovilas genuínas, a práxis e a teoria são expressas como propósitos e missões. É no exercício prático, cotidiano, das atividades em contextos locais e globais da realidade socioambiental que os princípios são testados. Abalizada pelo que Unger (1991) chama de "encantamento do humano", esta é uma de suas marcas de diferenciação com respeito ao ethos moderno. A tendência à hybris é controlada na medida em que seus membros se responsabilizam pelo todo e a perenização de seus projetos tem a proteção à vida, em suas múltiplas dimensões, como garantia continuada. É no momento presente que as respostas devem ser dadas aos desafios oferecidos pelas crises. Assim sendo, é salutar que não se veja as ecovilas como aldeias tradicionais, onde os saberes espirituais institucionalizam a vida social a partir da revisitação de verdades transcendentes. São experiências eminentemente híbridas, contemporâneas, de misturas de temporalidades e espacialidades múltiplas cujo elo é o cuidado, assim como proposto pelo mito ${ }^{2}$, mas cuja ação é garantida nos resultados factíveis de integração entre comunidades naturais e humanas (SANTOS JR, 2015). Se idealmente, as ecovilas genuínas são projetos que primam pela emancipação, porém, o ethos zeloso permanece como projeto aberto e em construção na experiência viva de cada grupo.

\section{REFERÊNCIAS}

[1] BANG, J, Martin. Ecovillages: A pratical guide to sustainable communities. Gabriola Island: New Society Publisherers, 2005.

[2] BARTHOLO, Roberto S. Jr. Os labirintos do silêncio: Cosmovisão e tecnologia na modernidade. São Paulo: Marco Zero; Rio de Janeiro: Coppe/UFRJ, 1986.

[3] BARTholo, R. S. Jr.; DElamaro, M. Modernidades e éticas. In: AYRES, A. R. et al. (Org.) Ética e responsabilidade social. Brasília, DF: SESI, 2002, cap. 1, p. 12-31.

[4] BOFF, Leonardo. Saber Cuidar. Ética do humano - compaixão pela terra. Petrópolis: Editora Vozes, 1999.

[5] ___ A busca de um ethos planetário. Revista perspectiva, BH, v. 40, p.165-179, 2008.

[6] DARDEL, Eric. O Homem e a terra: natureza da realidade geográfica. São Paulo: Perspectiva, 2011.

[7] DAWSON, J. Ecovillages: New Frontiers for Sustainability. Devon/UK: Green Books, 2006.

\footnotetext{
20 mito do Cuidado, apresentado pelo filósofo romano Higino, narra que o humano teria sido criado do barro pelo Cuidado, o qual solicitou à Júpiter, o Céu, que o animasse com o sopro da vida. 0 que foi feito. A Terra (Gaia) e Júpiter disputaram a nomeação deste novo ser, já que a primeira havia oferecido o material do qual foi feito e o segundo lhe ofereceu a Vida. Chamado a dirimir a querela, Saturno, o Tempo, proferiu a seguinte sentença: "Você, Júpiter, deu-lhe o espírito; receberá, pois, de volta este espírito por ocasião da morte da criatura. Você, Terra, deu-lhe o corpo; receberá, portanto, também de volta o seu corpo quando esta criatura morre. Mas como você, Cuidado, foi quem, por primeiro, moldou a criatura, ficará sob seus cuidados enquanto ela viver. E uma vez que entre vocês há acalorada discussão acerca do nome, decido eu: esta criatura será chamada Homem, isto é, feita de húmus, que significa terra Fértil” (HIGINO apud BOFF, 1999, p. 46).
} 
[8] ELIADE, Mircea. O Sagrado e o profano. Lisboa: Edição Livros do Brasil, 1980.

[9] GONÇALVES, W. C. Porto. O desafio ambiental. Rio de Janeiro: Record, 2004.

[10] HAESBAERT, R. Desterritorialização: entre redes e aglomerados de exclusão. In: CASTRO, I. et al. (Orgs.). Geografia: conceitos e temas. Rio de Janeiro: Bertrand Brasil, 1995.

[11] HEIDEGGER, M. Ser e Tempo. Trad. Márcia de Sá Carvalho, v. 1 Petrópolis: Vozes, 1988.

[12] __ A questão da técnica. In: HEIDEGGER, M. Ensaios e conferências. 3ª edição. Petrópolis: Vozes; Bragança Paulista: Ed. Univ. São Francisco, 2006, p. 11-38.

[13] IPCC, 2014. Climate Change 2014: Synthesis Report. PACHAURI, R.K et al. (eds.). IPCC, Geneva/Switzerland, 151 pp. Disponível em: <http://www.ipcc.ch/pdf/assessment-report/ar5/syr/SYR_AR5_FINAL_full.pdf >. Acesso em: 20 ago. 2015.

[14] JAEGER, W. Paidéia. A formação do homem grego. São Paulo: Martins Fontes, 1989.

[15] LEFF, Enrique. Ecologia, Capital e Cultura. Racionalidade Ambiental, Democracia Participativa e Desenvolvimento Sustentável. Edifurb, Blumenau, 2000.

[16] MORIN, E.; KERN, A. B. Terra-Pátria. Lisboa: Instituto Piaget, 1994.

[17] POLANYI, Karl. A grande transformação. As origens de nossa época. 9. ed. Rio de janeiro: Elsevier-Campus, 2000.

[18] LE PRESTRE, Philippe. Ecopolítica Internacional. São Paulo: SENAC, 2000.

[19] RODRIGUES, Arlete. Problemática ambiental, agenda ambiental. Espaço, território, classes sociais. Boletim Paulista de Geografia, São Paulo, n. 83, p. 91-109, Dezembro 2005.

[20] SANTOS, Milton. A Natureza do Espaço. Técnica e Tempo, Razão e Emoção. São Paulo: Hucitec, 1996.

[21] __ Por uma outra globalização. Do pensamento único à consciência universal. São Paulo: Record, 2000.

[22] SANTOS JR., Severiano José dos. Zelosamente habitando a Terra. Ecovilas genuínas, espaço geográfico e a construção de lugares zelosos em contextos contemporâneos de fronteiras paradigmáticas. 443 f. il. Tese (Doutorado) - Instituto de Geociências, Universidade Federal da Bahia, Salvador, 2016.

[23] TRAINER, Ted. The global ecovillage movement: The simpler way for a sustainable society. Social Alternatives, v. 19, no 3, 2000 .

[24] TUAN, Yi-Fu. Espaço e lugar: a perspectiva da experiência. São Paulo: DIFEL, 1983.

[25] UNGER, Nancy Mangabeira. O Encantamento do Humano. Ecologia e Espiritualidade. São Paulo: Loyola, 1991.

$94 \mathrm{p}$.

[26] VAZ, Henrique C. de L. Escritos de Filosofia II: Ética e cultura. São Paulo: Loyola, 1988.

[27] WIGHT, Alan. We are Nature: Exploring Ecovillagers' Perception of Nature and uses of Technology. Tese (Mestrado) - University of Cincinnati, Cincinnati, 2008. 


\section{Capítulo 3}

Contexto territorial e ambiental no Programa de Uso Público do PESM: A visão institucional

\section{Davis Gruber Sansolo}

Sidnei Raimundo

Eliane Simões

Juliana Marcondes Bussolotti

Resumo: 0 Parque Estadual Serra do Mar (PESM) ocupa de forma paralela a linha de costa do Estado de São Paulo. Foi criado em 1977 e contempla atualmente 332.000ha, abrangendo 23 municípios. Devido às grandes diferenças setoriais e dimensão, a gestão é efetuada a partir de sua subdivisão em 10 Núcleos Administrativos. Este estudo visa analisar a inserção do contexto territorial e ambiental no Programa de Uso Público em três desses Núcleos: Itutinga-Pilões (entre Cubatão e São Bernardo do Campo), Caraguatatuba (no município de mesmo nome) e Picinguaba (Ubatuba). Trata-se de uma pesquisa qualitativa baseada na análise de conteúdo a partir de documentos (atas de reuniões, instrumentos de gestão) e entrevistas. Constatou-se que a gestão do Uso Público é efetuada de maneira profundamente diferente em cada Núcleo conforme: perfil do gestor, composição da equipe de trabalho (experiência e capacidade de atendimento), concepção de educação ambiental e de turismo características socioambientais do entorno, demandas de uso público já existentes nas diversas áreas de visitação.

Palavras-chave: Área Protegida, Desenvolvimento Regional, Turismo, Educação Ambiental. 


\section{CENÁRIO: USO PÚBLICO EM ÁREAS PROTEGIDAS}

Os primeiros parques nacionais foram criados nos Estados Unidos inspirados no pintor sobre comunidades indígenas, George Catlin. Em uma viajem que fez para a região de Dakota observou a destruição da cultura indígena e da vida selvagem em geral propondo um conceito novo para a época calcado na proteção do território natural e selvagem como parte de uma nação: "by some great protecting policy of government (...) in a magnificent park (...) a nation's park, containing man and beast, in all the wild[ness] and freshness of their nature's beauty!" (HARPER FERRY CENTER, 1991, p.12).

A proteção do patrimônio cultural foi considerada inviável na época. Portanto a visão romântica sobre a vida selvagem retratada por pintores e desenhistas, em oposição a visão de natureza a ser explorada, orientou a criação de áreas protegidas nos Estados Unidos da América no final do século XIX. Em 1864 foi criado o Parque Nacional de Yosemite, sob o patrocínio de alguns ricos moradores da Califórnia, com o objetivo de: "beheld for public use, resort, and recreation... inalienable for all time" (Id. Ibid.), denotando que em sua gênese os parques foram idealizados para proteger a natureza em benefício do lazer e do turismo e sob auspícios do estado.

O Parque de Yelowstone foi criado entre 1869 e 1871 sendo defendido pelos políticos da época como um território voltado ao uso público de forma a não deixá-lo cair em mãos privadas (Id. Ibid). Portanto, dois aspectos caracterizam a concepção norte americana na criação de parques nacionais: a natureza a ser preservada como parte da identidade nacional e o território natural voltado ao uso público, inclusive como estratégia de fortalecimento da nação. Ambos os aspectos se configuram como princípios, como ideário que fundamenta estas políticas públicas até hoje. Dentre esses fundamentos é ressaltada a função do poder público em resguardar para si a gestão e o domínio dessas áreas protegidas. Ao mesmo tempo, destinar a função desses territórios à proteção da natureza e ao usufruto da sociedade industrial.

0 processo de criação, planejamento e gestão de áreas protegidas no Brasil, tem sua matriz nesse modelo norte americano, cujos objetivos envolviam a oferta de áreas naturais pouca transformadas, com baixa presença do ser humano, para o lazer das populações habitantes das cidades industrializadas (DIEGUES, 2000).

No final do século XIX, quase que simultaneamente ao processo americano, na Europa, mais precisamente no Reino Unido, a partir de iniciativas da sociedade civil, foram criadas reservas da natureza com o objetivo de proteger os habitats naturais contra a pressão advinda do processo de industrialização e urbanização do país (MORSELLO, 2001).

O Sistema Nacional de Unidades de Conservação (SNUC-2002), marca um processo que vem assumindo características peculiares. Em primeiro lugar, resultou de um grande debate nacional entre sociedade civil e estado que se prolongou por dez anos. Em segundo, foi estruturado em duas grandes categorias: proteção integral e uso sustentável. Em terceiro, abriu-se um grande espaço de participação social no diálogo sobre a produção e gestão territorial. A relação entre proteção da natureza e desenvolvimento passou a considerar a sociobiodiversidade como um valor a ser incluso na política pública nacional.

No caso dos parques nacionais, desde sua origem, o uso público esteve no centro de seus objetivos. Conforme está presente nas diretrizes de visitação em Unidades de Conservação propostas pelo Ministério do Meio Ambiente do Brasil:

A visitação no Sistema Nacional de Unidades de Conservação da Natureza (.....) deve ser cuidadosamente planejada para que possa cumprir os objetivos de sua criação, além de funcionar como uma ferramenta de sensibilização da sociedade sobre a importância da conservação da biodiversidade e como um vetor de desenvolvimento local e regional (BRASIL, 2006, p.9).

A afirmação explicita a função do uso público na difusão de um ideário conservacionista que ultrapassa a noção de normalização territorial, visa a influência no processo de produção do espaço.

Essa perspectiva aparece mais evidente na exposição dos princípios propostos pelo Ministério do Meio Ambiente para a visitação e áreas protegidas como no caso do item b:

A visitação é instrumento essencial para aproximar a sociedade da natureza e despertar a consciência da importância da conservação dos ambientes e processos naturais, independentemente da atividade que se está praticando na Unidade de Conservação (BRASIL, 2006, p. 9). 
Portanto, nos princípios propostos pelo Ministério do Meio Ambiente, as atividades como educação ambiental e turismo são tratadas como instrumento de política pública que visa o estabelecimento de interações entre uma unidade de conservação e a população em geral, coerente com a ideia de que o meio ambiente é um bem de interesse difuso, conforme a Constituição de 1988.

A visitação em áreas protegidas oferece a possibilidade de reflexão sobre o espaço produzido urbanoindustrial (LEFEBVRE, 1974), quando em contato com uma paisagem contrastante presente em um parque.

Um parque é um espaço delimitado por uma dinâmica tensionada pelos ritmos da natureza da cidade. Embora a paisagem seja contrastante à da cidade, é também resultante, ainda que se possa dizer que de forma contraditória, de um processo de produção do espaço urbano industrial.

Todavia, em um parque a natureza permite ao visitante experimentar o contraste, observar outros processos, além daqueles resultantes da produção do espaço urbano. As relações possíveis de observação entre meio físico e biótico e entre os próprios organismos de diferentes ordens, propiciam a reflexão sobre o ser humano como parte da dinâmica da natureza.

Lemelin et al. (2015) indicam que um dos aspectos do ceticismo da população local, próxima às áreas protegidas, relacionados a iniciativas de desenvolvimento do turismo associado à conservação, deriva do desconhecimento do processo histórico de produção do espaço, que dificulta o desenvolvimento do sentido de pertencimento a uma comunidade, a um território ou ao que Zaoual (2006) chamava de sítio simbólico de pertencimento.

A necessidade de utilização do espaço ocupado pela natureza ou mesmo, de uso dos recursos naturais pela população próxima à área protegida pode ser um fator que dificulta a compreensão da importância de definir espaços especialmente protegidos. Por outro lado, para os que vêm de outros lugares, outros sítios simbólicos, a ausência de uma intepretação do território, da paisagem, pode levar à busca daquilo que lhe é familiar, isto é, a natureza mercantilizada, da paisagem como produto a ser consumido.

Esse trabalho é parte de um projeto de pesquisa (0 Contexto Territorial e Ambiental no Programa de Uso Público do Parque Estadual da Serra do Mar - PESM), apoiado pela Fundação de Amparo à Pesquisa de São Paulo (FAPESP, Processo no 2013-20035-3) que busca compreender a maneira como essa área protegida (PESM, Figura 1) interage com os setores da sociedade no contexto territorial no qual está inserido. Visa também verificar a gestão do Programa de Uso Público frente às novas demandas que a sociedade nacional tem incentivado na região por meio da implantação de empreendimentos de exploração de hidrocarbonetos e logística.

Figura1- Parque Estadual Serra do Mar (observa-se que neste mapa ainda não constam os Núcleos Administrativos criados mais recentemente: N. Bertioga - 2012 e N. Padre Dória - 2014).

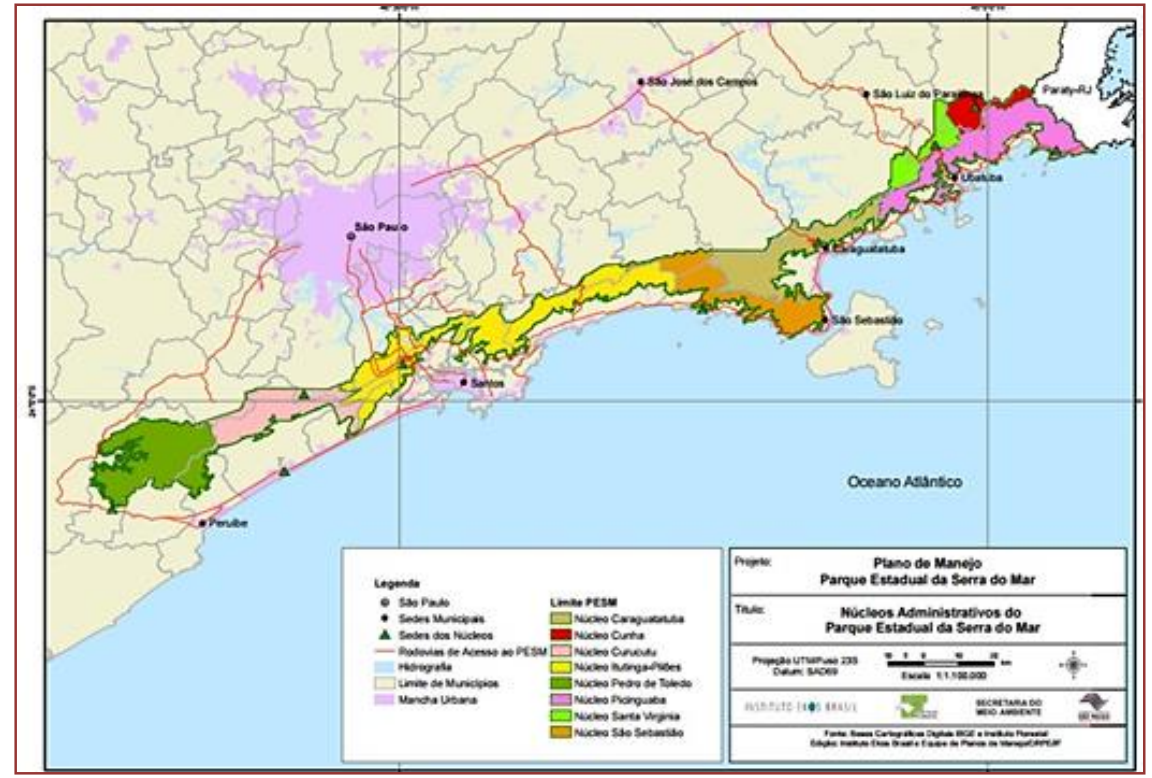

Fonte: SÃO PAULO, (2006) 
Neste estudo são apresentados os principais resultados obtidos nas entrevistas com os responsáveis pelo Programa de Uso Público dos Núcleos Itutinga-Pilões, Caraguatatuba e Picinguaba discutindo suas representações a respeito dessa temática. É fruto também de um processo de reunião de histórias de profissionais que atuam há mais de 20 anos junto ao Parque Estadual Serra do Mar, tanto como atores sociais como pesquisadores.

\section{ASPECTOS METODOLÓGICOS}

As entrevistas foram elaboradas por meio de processo de construção em passos: i) reuniões preliminares entre o coordenador e alunos de graduação do curso de Biologia da Universidade Estadual Paulista (Unesp), Campus São Vicente, para uma proposição preliminar de aspectos chave para composição do roteiro de entrevista e formas de registros das mesmas ii) reuniões gerais de integração com os demais pesquisadores e discussão sobre os instrumentos propostos; iii) aplicação das entrevistas em campo registo em áudio/anotações; iv) transcrição, tabulação e análise preliminar; v) seminários internos de todo o grupo para discussão e consolidação de resultados.

A abordagem teórico-metodológica escolhida fundamentou-se na análise de conteúdo (BARDIN, 1977) a partir da interpretação de dados registrados em atas e documentos de gestão, mas principalmente dos significados dos discursos dos entrevistados, já que a conversação possibilita a compreensão de um universo consensual, moldando e animando as representações sociais (SPINK, 2004).

Previamente à elaboração das entrevistas foram elencadas categorias de análise, como indica Duarte (2004), denominadas aqui como chaves de interpretação. A partir delas, as perguntas foram elaboradas. Dessa forma, roteiros de entrevistas estruturados (diretivos) baseados nestas chaves de interpretação foram aplicados aos Gestores, aos Coordenadores do Programa de Uso Público e aos Monitores Ambientais de cada Núcleo. As entrevistas gravadas e transcritas foram enviadas aos entrevistados para validação do conteúdo.

\section{CHAVES DE INTERPRETAÇÃO}

A primeira chave de interpretação refere-se ao vínculo dos responsáveis pelo uso público ao território em que trabalham. A grande maioria dos Monitores atua no Parque há menos de três anos. Somente o Coordenador do Uso Público do Núcleo Itutinga detém relação temporal mais longa: 28 anos de trabalho no local (é um servidor público, concursado). As entrevistas indicam que isso decorre do formato de contratação da equipe destinada à gestão do Uso Público: a maior parte dos monitores é contratada por uma empresa terceirizada e, portanto, não são funcionários da Fundação Florestal (órgão gestor das Unidades de Conservação). Os contratos dispõem de tempo determinado e há uma grande alternância nessas funções o que dificulta um maior envolvimento com o território e a interpretação do mesmo para os visitantes.

A segunda chave refere-se à compreensão que os entrevistados apresentam sobre o Parque Estadual Serra do Mar. De maneira geral o termo Mata Atlântica foi o mais presente nas respostas dos entrevistados, o que denota uma compreensão sobre o domínio da paisagem em que se encontra o parque e sua importância para conservação. 0 Gestor de Picinguaba ainda atribuiu ao Parque um valor estratégico de conservação ao indicar o contexto que o cerca, isto é, regiões urbanizadas. Também em Picinguaba aparecem respostas dos Monitores relativas à relação do Parque com as comunidades tradicionais.

A terceira chave de intepretação refere-se à representação que cada entrevistado dispõe do Núcleo onde trabalha. Tanto no Núcleo Itutinga-Pilões quanto em Caraguatatuba foram obtidas respostas relacionadas à questão da manutenção dos recursos hídricos. As atividades relacionadas ao uso público foram citadas como relevantes no Núcleo Caraguatatuba, sobretudo ações de educação ambiental e a visita às cachoeiras. Isso indica o caráter de ludicidade que a visitação pode proporcionar, ainda que o foco seja a reflexão a respeito da água. Quanto aos aspectos negativos mencionados nos três Núcleos foi destacada a intermitência dos gestores no cargo.

Outros tópicos foram destacados de forma peculiar em cada Núcleo: no Núcleo Picinguaba a comunidade moradora foi considerada aspecto positivo pelo gestor. Tal posicionamento pode ser explicado pelo relacionamento desenvolvido entre o Parque e as comunidades tradicionais que o habitam há pelo menos duas centenas de anos. Embora os conflitos sejam parte desse relacionamento, no Plano de Manejo, elaborado em 2006, foi estabelecida a Zona Histórica-Cultural Antropológica, de forma inédita e ainda exclusiva em âmbito nacional, na qual foi admitida a permanência e desenvolvimento socioeconômico das 
comunidades tradicionais, caiçaras e quilombolas, mesmo dentro da Unidade de Proteção Integral (Parque).

A quarta chave de intepretação foi o significado de uso público. De forma geral os entrevistados indicaram que o Programa de Uso Público segue o que está previsto no Plano de Manejo do PESM (SÃO PAULO, 2006).

A quinta chave de interpretação refere-se à educação ambiental. As entrevistas demonstram que o público atendido pelo Subprograma de Educação Ambiental é principalmente escolar. Entretanto, identificou-se que também há um trabalho sendo desenvolvido com a comunidade do Rio do Ouro em Caraguatatuba, contígua ao parque.

A sexta chave de interpretação refere-se à visitação em geral. Nos três Núcleos a visitação é realizada por turistas, isto é, visitantes em seus momentos de lazer, portanto em seu tempo livre, que frequentam principalmente as trilhas do Parque e a praia (no caso do N. Picinguaba). Ao longo das trilhas, observa-se a vegetação, eventualmente a fauna, mas um dos atrativos principais são as cachoeiras (nos três Nú cleos). 0 Núcleo Picinguaba apresenta também como distinção o fato de oferecer trilhas nos diversos ecossistemas que protege, além da possibilidade de visita às comunidades tradicionais.

A sétima chave de intepretação refere-se à relação das comunidades com o Parque. Os três Núcleos se distinguem nessa questão. Os responsáveis pelo uso público no Núcleo Itutinga-Pilões indicaram que vêm desenvolvendo atividades nos Bairros Cota por meio do Programa de Recuperação Socioambiental da Serra do Mar.

No caso do Núcleo Caraguatatuba, foi relatado que no passado, em um outro momento da gestão do Núcleo, havia uma relação muito próxima com uma das comunidades do entorno, sobretudo com o Bairro do Rio do Ouro, onde vive população de baixa renda. Após a mudança da gestão, a comunidade do entorno já não usa o parque na mesma intensidade.

No Núcleo Picinguaba as comunidades são consideradas conteúdo do Programa de Uso Público e também participam ativamente da prestação de serviços: alguns moradores são funcionários; fazem a gestão do estacionamento, da lanchonete e da Casa de Farinha (um moinho movido à roda d' água); e atuam como Monitores Ambientais autônomos. São oferecidas visitas às comunidades do Cambury e do Quilombo da Fazenda, onde se pode agendar rodas de conversa, serviço de alimentação contemplando gastronomia local e visita aos territórios tradicionais.

Finalmente, a oitava chave refere-se à terceirização do programa de uso público. De forma geral as opiniões nos três Núcleos trataram da possibilidade da terceirização da mão de obra relacionada ao Programa de Uso Público. Há alguns que indicam a eficiência da gestão da mão de obra, facilitando a contratação para o trabalho. No Núcleo Picinguaba os monitores se posicionaram favoravelmente à terceirização desde que se privilegie a contratação de representantes das comunidades.

\section{USO PÚBLICO (DES)CONTEXTUALIZADO?}

As respostas indicam peculiaridades de cada Núcleo e que a visão do Parque como um todo é construída a partir do conhecimento do local, de suas singularidades.

Nos três Núcleos há uma representação das comunidades junto ao Conselho Gestor (ou Conselho Consultivo de cada Núcleo, conforme previsto no SNUC), mas somente nos Núcleos Picinguaba e Caraguatatuba há monitores que são moradores da comunidade (interior da UC e/ou Zona de Amortecimento, respectivamente).

Percebe-se por parte dos responsáveis pelo Programa de Uso Público que a visitação/lazer é um fator favorável ao processo de promoção de reflexão sobre a conservação ambiental. Quanto ao significado atribuído à Educação Ambiental, os termos e conteúdos citados foram distintos entre os Monitores e Coordenadores de Uso Público dos três Núcleos.

Os termos comuns a todos os entrevistados foram: "proteção dos recursos", "cuidar da floresta", "refúgio da biodiversidade", "conservação dos biomas". Traduz representação do Parque como uma natureza viva, entretanto, não aparece a natureza como ecossistema, isto é, não expressam uma visão sistêmica, mas genérica, ou pontual, sem relação entre os organismos e entre os organismos e o meio físico. Isso ainda é mais exacerbado com relação ao contexto territorial em que o Parque está instalado: o entorno, as questões presentes no território ao redor não são trabalhadas ou pouco são abordadas nas atividades de 
uso público, com exceção da questão das comunidades tradicionais e seu uso histórico do espaço em sobreposição com a área protegida que é um dos temas do Programa de Uso Público no N. Picinguaba.

De forma geral a perspectiva do Parque como espaço público não está presente no discurso institucional. Restringe-se à visita de grupos organizados escolares (incluindo universitários) e ao público em geral sem perfil definido que percorrem trilhas, rios e praias. Não há de forma enfática um olhar para moradores do entorno do Parque e, portanto, não são desenvolvidas atividades nem estrutura para receber os moradores (exceto no Núcleo Caraguatatuba, de forma ainda incipiente). Há um claro direcionamento das atividades e da estrutura quase que exclusivamente ao público escolar. Por um lado, esse resultado pode significar uma subavaliação dos usuários que se relacionam com o parque e por outro lado um despreparo para atender a diversidade de usuários.

Em síntese, o que se percebeu foi a ausência de uma política de uso público clara, pensada institucionalmente como um instrumento relacional entre o parque e a população em geral. Dessa forma a importância do uso público é simplificada, fragilizada, o que torna passível a delegação a terceiros (muitas vezes estranhos à política pública, ou mesmo aos lugares), a função e a responsabilidade do desenvolvimento do Programa de Uso Público, podendo torná-lo uma mera mercadoria.

\section{AGRADECIMENTOS}

Agradecemos o apoio da Fapesp para o desenvolvimento desse estudo e dos alunos de graduação em Biologia da Unesp: Camila Issegawa, Jorge Aragon, Danielle Almeida de Carvalho e Stefano Ávila que atuaram na coleta e interpretação dos dados, sem os quais, essa análise não teria sido possível.

\section{REFERÊNCIAS}

[1] BARDIN, L. Análise de Conteúdo. Lisboa: Edições 70 LDA, 1977.

[2] BRASIL (MMA). Diretrizes para Visitação em Unidades de Conservação. Brasília, MMA, IBAMA, 2006.

[3] DIEGUES, A. C. S.. O mito moderno da natureza intocada. São Paulo: Hucitec, 2000.

[4] DUARTE, R. Entrevista em pesquisas qualitativas. Educar, Ed. UFPR, n. 24. Paraná, 2004.

[5] HARPERS FERRY CENTER. The National Parks: Shaping the System. Washington D.C. Harpers Ferry Center, National Park Service U.S. Department of the Interior, 1991.

[6] LEMELIN, R. H.; et. al. People, Places, Protected Areas and Tourism: Place Attachment in Rossport, Ontario, Canada Scandinavian. Journal of Hospitality and Tourism Volume:15 Edição:1-2 .p. 167-182, 2015.

[7] LEFEBVRE, H. La production de l'espace. In: Le Homme et la société, N. 31-32, 1974. Sociologie de la connaissance marxismeet anthropologie. pp. 15-32.

[8] MORCELLO, C. Áreas protegidas públicas e privadas: seleção e manejo. São Paulo, Annablume, 2001.

[9] SÃo PAUlo (Estado/SMA). Plano de manejo do Parque Estadual da Serra do Mar. São Paulo, Secretaria Estadual do Meio Ambiente, Instituto Florestal, 2006.

[10] SPINK, M. J. P. O conceito da representação social na abordagem psicossocial. Cad. Saúde Pública 9 (3): 300 308, jul/set. Rio de Janeiro, 1993

[11] ZAOUAL, Hassan. Nova Economia das Iniciativas Locais: uma introdução ao pensamento pós-global. Rio de Janeiro: DP\&A; COPPE/UFRJ, 2006. 


\section{Capítulo 4}

\section{Os conhecimentos climáticos nos livros didáticos de Geografia do Ensino Fundamental}

\section{Thiago Amancio Gonçalves}

Thiara Messias de Almeida Teixeira

Amom Chrystian de Oliveira Teixeira

Resumo: 0 trabalho avaliou se os conhecimentos climáticos que aparecem nos livros didáticos utilizados pelos professores da segunda etapa do Ensino Fundamental das escolas selecionadas no município de Cabeceiras-GO levam o aluno ao desenvolvimento do pensamento crítico e integrado da realidade. Foram escolhidas as Coleções Projeto Araribá e Jornadas.geo, que foram avaliadas qualitativamente, tendo por base as exigências e indicações dos Parâmetros Curriculares Nacionais, do Currículo Referência da Rede Estadual de Educação de Goiás e do Guia de Livros Didáticos de 2014. Os livros analisados são coesos e correntes e adequam-se bem aos principais documentos legais que regem a educação no estado. De forma geral, a apresentação dos conteúdos climáticos foi avaliada como de boa qualidade e bem estruturada, contribuindo para o desenvolvimento do pensamento crítico e integrado da realidade pelos alunos.

Palavras-chave: Climatologia na Escola, Ensino de Geografia, Livro Didático. 


\section{INTRODUÇÃO}

Desde os primórdios de seu desenvolvimento, o homem entendeu que necessitava conhecer os fenômenos climáticos, uma vez que estes poderiam exercer influência sobre seu modo de viver. Embora observar o clima seja um processo que acompanhou as sociedades ao longo da história, Mendonça e Danni-Oliveira (2007) afirmam que os gregos foram os primeiros a apresentar, de forma mais coerente, reflexões sobre o comportamento do clima a partir das observações sobre as suas variações temporais e espaciais e da inferência acerca dos princípios que controlam esses fenômenos.

Os conhecimentos climáticos acumulados ao longo do processo de evolução do ser humano a partir das necessidades de entender os fenômenos naturais que se manifestavam no meio o qual estavam inseridos, continuam a exercer grande influência no mundo atual, principalmente no processo de ensinoaprendizagem, uma vez que possibilita ao aluno "construir raciocínios lógicos sobre as leis que regulam o universo dos fenômenos naturais, reconhecendo a relevância desse conhecimento tanto para a continuidade do avanço das ciências da natureza como para a sua vida prática" (BRASIL, 1998, p. 60).

Muitos são os fatores que interferem no processo de ensino-aprendizagem e influenciam na transmissão de conteúdos através da prática educativa. Utilizar-se de recursos didáticos que auxiliam na aprendizagem, tais como os livros didáticos que são uma importante ferramenta de ensino, muitas vezes, é questionado sobre as abordagens adotadas no que concerne aos conteúdos a serem ensinados, uma vez que segundo Pina (2009), o conhecimento fica limitado a esse recurso, sendo desta maneira, de fundamental importância analisar os conteúdos por ele propostos em relação as expectativas de ensino apresentadas tanto pelos Parâmetros Curriculares Nacionais (PCNs) como pelo currículo referência na disciplina de Geografia. Daí a necessidade de se analisar o livro didático adotado pelo professor em sua prática pedagógica, devido à importância a ele atribuída.

É interessante ainda observar um elemento de grande relevância no processo de ensino que dá margem para que o aluno possa construir e desenvolver sua própria opinião, se apropriando dos conhecimentos e construindo suas próprias concepções: a criticidade, que permite que o mesmo desenvolva seu pensamento crítico-reflexivo e associe através desse modo de pensar o que se é estudado em sala de aula com seu cotidiano.

Diante dessas observações, buscou-se através da pesquisa investigar se os conteúdos de Climatologia abordados nos livros didáticos de Geografia do Ensino Fundamental levam o aluno ao desenvolvimento do pensamento crítico e integrado da realidade? A temática nos instiga a escrever e pesquisar sobre o referido assunto, visto que, conhecer os processos e dinâmicas acerca dos conhecimentos climáticos são essenciais na formação do saber geográfico básico de cada indivíduo.

A problemática identificada e os questionamentos que surgiram deram margem para que fosse definido o seguinte objetivo norteador desse estudo: Avaliar se os conhecimentos climáticos que aparecem nos livros didáticos utilizados pelos professores do Ensino Fundamental II das escolas selecionadas no município de Cabeceiras-GO levam o aluno ao desenvolvimento do pensamento crítico e integrado da realidade.

Mediante o exposto, é pertinente nesse momento a indagação: Mas, porque analisar os conhecimentos climáticos? Ou até mesmo, qual a importância de tais conhecimentos?

Devido aos frequentes debates que a sociedade vem enfrentando diante das consequências das mudanças climáticas, a compreensão de como ocorrem e como se originam tais fenômenos e, até mesmo o que são tais fenômenos, vem se tornando um conhecimento essencial para que saibam como lidar com os problemas que daí se originam.

Um dos principais meios que possibilita entrar em contato com esse conhecimento é o educacional, que proporciona através do ensino da Geografia que o aluno se aproprie de conhecimentos que o possibilite entender tais fenômenos, comumente denominados como conhecimentos climáticos.

\section{PROCEDIMENTOS METODOLÓGICOS}

0 trabalho constituiu-se, inicialmente de uma pesquisa bibliográfica sobre o uso e importância do livro didático, o ensino e a Geografia Escolar. Posteriormente, percorreu-se as escola públicas do Ensino Fundamental II de Cabeceiras-GO, a saber: Colégio Estadual Padre Lamberto Verrijt e Colégio Estadual Professor Alfredo Nasser para verificar quais as principais coleções de livros didáticos de Geografia utilizados pelos professores. Nesse sentido, a análise foi desenvolvida por meio de uma pesquisa 
qualitativa, onde avaliou-se os livros do $6^{\circ}$ ao $9^{\circ}$ ano das Coleções Projeto Araribá do ano de 2007, da Editora Moderna e Jornadas.geo do ano de 2012, da Editora Saraiva (Figura 01).

Figura 01: (a) Coleção Projeto Araribá da Editora Moderna; (b) Coleção Jornadas.geo Editora Saraiva.

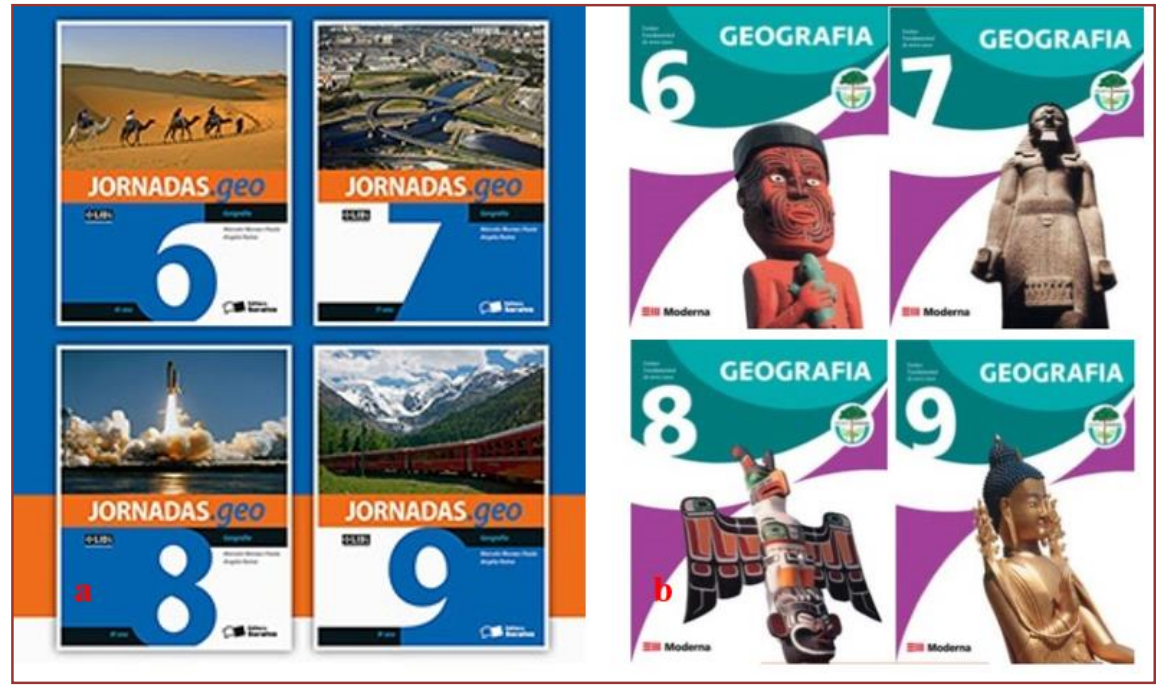

Os procedimentos adotados, seguiu as etapas: a) Visita às escolas do Ensino Fundamental realizada no segundo semestre de 2015 para identificação dos livros utilizados pelos professores regentes na disciplina de Geografia; b) Delimitação dos critérios de análise; c) Apreciação dos livros quantos aos conhecimentos climáticos que abordam; d) Análise dos conteúdos que dizem respeito aos conhecimentos climáticos; e) Avaliação e discussão dos resultados averiguados.

Buscou-se efetuar uma análise em prol de averiguar se os conhecimentos climáticos no material didático são capazes de levar o aluno ao pensamento crítico e integrado da realidade, pesquisa esta embasada no que se propõe para o ensino da Geografia através dos PCNs de Geografia e do Currículo Referência da Rede Estadual de Educação de Goiás. Convém destacar, que foi utilizado o Guia de Livros Didáticos de 2014 dos anos finais do Ensino Fundamental para a definição dos critérios de análise, tomando como base as resenhas elaboradas para análise de cada coleção recomendada.

Os dados obtidos através da análise foram dispostos considerando-se os critérios definidos: Coesão e coerência, estrutura, conteúdos e conceitos climáticos, qualidade e quantidade, integração, abordagem do livro de acordo com os PCNs e adequação do livro a concepção de Geografia Escolar.

\section{ANÁLISE DOS CONHECIMENTOS CLIMÁTICOS NOS LIVROS DIDÁTICOS DE GEOGRAFIA DO ENSINO FUNDAMENTAL}

Cabe neste momento, compreender o que vem a ser a Climatologia. De acordo com Mendonça e DanniOliveira (2011, p. 15) "constitui do estudo científico do clima. Ela trata dos padrões de comportamento da atmosfera em suas interações com as atividades humanas e com a superfície do planeta durante um longo período de tempo", ou seja, tal área de estudo da Geografia visa estudar os aspectos climáticos de uma dada superfície se estabelecendo nesse sentido entre as ciências humanas e ciências naturais.

No âmbito educacional:

A Climatologia é para desenvolver a participação dos alunos nas discussões e decisões sobre a questão ambiental, vinculadas aos problemas ambientais urbanos e mudanças climáticas em espacial, já que essas, passam a fazer parte do cotidiano e do processo de formação das classes sociais, todos precisam preservar para ter uma qualidade de vida, ou seja, uma vida saudável (MATIAS, 2004, p. 9).

Isto é, ao tratar-se da Climatologia dentro da sala de aula, seus conhecimentos buscam levar o aluno a compreender as questões pertinentes na relação sociedade-natureza (Clima), tendo em vista sua 
importância na vida cotidiana de cada indivíduo e das inúmeras problemáticas que contrastam o cenário mundial e local no que concerne a manifestação de tais fenômenos.

É justamente acerca da importância dos conhecimentos climáticos no enfoque do desenvolvimento no pensamento crítico do aluno através de sua abordagem nos livros didáticos de Geografia que se baseia a análise a seguir.

Através das coleções selecionadas, pode-se observar no Quadro 1, a abordagem da temática Clima, quanto aos conteúdos que remetem a conhecimentos climáticos em relação aos volumes que compõe cada coleção a ser analisada:

\begin{tabular}{|c|c|c|c|}
\hline $\begin{array}{l}\text { Coleção/ } \\
\text { autor }\end{array}$ & $\begin{array}{l}\mathbf{A} \\
\mathbf{n} \\
\mathbf{0}\end{array}$ & CONTEUDOS PROPOS & OS POR VOLUME E SÉRIE \\
\hline \multirow{6}{*}{$\begin{array}{l}\text { Jornadas.geo } \\
\text { Rama e Paula } \\
\text { (2012) }\end{array}$} & $6^{\circ}$ & $\begin{array}{l}\text { Unidade 7: Clima - Dinâmica } \\
\text { Natural e Atividades } \\
\text { Humanas }\end{array}$ & $\begin{array}{l}\text { - Tempo atmosférico e Clima; } \\
\text { - Os fatores do Clima; } \\
\text { - Climas da terra; } \\
\text { - O Clima e as atividades humanas. }\end{array}$ \\
\hline & $7^{\circ}$ & $\begin{array}{l}\text { Unidade 4: Vegetação e } \\
\text { Clima no Brasil }\end{array}$ & $\begin{array}{l}\text { - O Clima no Brasil; } \\
\text { - Os tipos de Clima no Brasil. }\end{array}$ \\
\hline & \multirow[t]{2}{*}{$8^{\circ}$} & $\begin{array}{l}\text { Unidade 2: América- } \\
\text { Continente de Grandes } \\
\text { Contrastes }\end{array}$ & - Dinâmicas do Clima e formações vegetais. \\
\hline & & $\begin{array}{l}\text { Unidade 5: } 0 \text { Continente } \\
\text { Africano }\end{array}$ & $\begin{array}{l}\text { - Aspectos naturais do território (Clima e paisagens } \\
\text { naturais). }\end{array}$ \\
\hline & \multirow[b]{2}{*}{$9^{\circ}$} & $\begin{array}{l}\text { Unidade 3: O Continente } \\
\text { Europeu }\end{array}$ & - Climas e formações vegetais da Europa. \\
\hline & & $\begin{array}{l}\text { Unidade 6: O Continente } \\
\text { Asiático }\end{array}$ & - Ásia: Elementos naturais (Clima e vegetação). \\
\hline \multirow{11}{*}{$\begin{array}{l}\text { Projeto } \\
\text { Araribá } \\
(2007)\end{array}$} & $6^{\circ}$ & $\begin{array}{l}\text { Unidade 5: Clima e } \\
\text { Vegetação }\end{array}$ & $\begin{array}{l}\text { - O Clima; } \\
\text { - Os Climas da Terra e do Brasil. }\end{array}$ \\
\hline & \multirow{4}{*}{$7^{\circ}$} & Unidade 4: Região Norte & - Aspectos físicos da Região Norte: O Clima. \\
\hline & & Unidade 5: Região Nordeste & $\begin{array}{l}\text { - Aspectos físicos da Região Nordeste: O Clima } \\
\text { semiárido. }\end{array}$ \\
\hline & & Unidade 7: Região Sul & - Aspectos físicos da Região Sul: O Clima subtropical. \\
\hline & & $\begin{array}{l}\text { Unidade 8: Região Centro- } \\
\text { Oeste }\end{array}$ & - Aspectos físicos da Região Centro-Oeste: O Clima. \\
\hline & \multirow{4}{*}{$8^{\circ}$} & $\begin{array}{l}\text { Unidade 3: O Continente } \\
\text { Americano }\end{array}$ & - Clima e vegetação da América. \\
\hline & & $\begin{array}{l}\text { Unidade 5: A América do } \\
\text { Norte }\end{array}$ & $\begin{array}{l}\text { - Estados Unidos: Território e população (Os aspectos } \\
\text { naturais do território estadunidense - Clima e } \\
\text { vegetação). }\end{array}$ \\
\hline & & $\begin{array}{l}\text { Unidade 6: América Central, } \\
\text { América Andina e Guianas }\end{array}$ & $\begin{array}{l}\text { - América Central: Continental e insular (América } \\
\text { Central insular: território e população - aspectos } \\
\text { físicos); } \\
\text { - América Andina: Chile, Bolívia e Peru (América } \\
\text { Andina: território, população e economia - Clima e } \\
\text { vegetação). }\end{array}$ \\
\hline & & Unidade 7: América Platina & $\begin{array}{l}\text { - América Platina: Aspectos gerais (Características } \\
\text { físicas - O Clima e a vegetação). }\end{array}$ \\
\hline & \multirow{2}{*}{$9^{\circ}$} & $\begin{array}{l}\text { Unidade 3: O Continente } \\
\text { Europeu }\end{array}$ & $\begin{array}{l}\text { - Quadro natural e problemas ambientes (o Clima e as } \\
\text { paisagens). }\end{array}$ \\
\hline & & $\begin{array}{l}\text { Unidade 5: O Continente } \\
\text { Asiático }\end{array}$ & $\begin{array}{l}\text { - Ásia: Um continente de contrastes (regionalização da } \\
\text { Ásia - Aspectos físicos e economia). }\end{array}$ \\
\hline
\end{tabular}


Observando tais características apresentadas em cada volume e a abordagem dos conhecimentos climáticos, foram empregados os seguintes critérios como agentes orientadores da análise (Quadro 2):

Quadro 2: Critérios de análise empregados na pesquisa.

\begin{tabular}{|c|c|c|c|c|c|c|c|c|c|c|c|c|c|}
\hline & Critérios & CRITÉ & OS D & $\begin{array}{l}\text { E AN } \\
\text { oleç } \\
\text { nada }\end{array}$ & $\begin{array}{l}\text { LISE } \\
\text { o } \\
\text { geo }\end{array}$ & DAS & & & Pro & $\begin{array}{l}\text { ole } \\
\text { to } A\end{array}$ & arit & & \\
\hline & Há coesão e coerência & & & & SIM & & & & & & SIM & & \\
\hline & textual em sua & NAO & $6^{\circ}$ & $7^{\circ}$ & $8^{\circ}$ & $9^{\circ}$ & - & NAO & $6^{\circ}$ & $7^{\circ}$ & $8^{\circ}$ & $9^{\circ}$ & - \\
\hline 1 & abordagem no que & & & & & & I & & & & & & I \\
\hline & tange aos & & & & & & $\mathrm{R}$ & & & & & & $\mathrm{R}$ \\
\hline & $\begin{array}{l}\text { conhecimentos } \\
\text { climáticos? }\end{array}$ & & $\mathrm{X}$ & $\mathrm{X}$ & $\mathrm{X}$ & $\mathrm{X}$ & $\mathrm{S}$ & & $\mathrm{X}$ & $\mathrm{X}$ & $\mathrm{X}$ & $\mathrm{X}$ & $\mathrm{S}$ \\
\hline & & & & & SIM & & & & & & SIM & & \\
\hline & A estrutura da Unidade & NAO & $6^{\circ}$ & $7^{\circ}$ & $8^{\circ}$ & $9^{\circ}$ & - & NAO & $6^{\circ}$ & $7^{\circ}$ & $8^{\circ}$ & $9^{\circ}$ & - \\
\hline 2 & auxiliam no processo de & & & & & & $\mathrm{I}$ & & & & & & $\mathrm{I}$ \\
\hline & auxrendizagem? & & $\mathrm{X}$ & $\mathrm{X}$ & $\mathrm{X}$ & $\mathrm{X}$ & $\mathrm{R}$ & & $\mathrm{X}$ & $\mathrm{X}$ & $\mathrm{X}$ & $\mathrm{X}$ & $\mathrm{R}$ \\
\hline & & & & & & & $\mathrm{S}$ & & & & & & $\mathrm{S}$ \\
\hline & Os conteúdos e & & & & SIM & & & & & & SIM & & \\
\hline & conceitos climáticos são & NAO & $6^{\circ}$ & $7^{\circ}$ & $8^{\circ}$ & $9^{\circ}$ & - & NAO & $6^{\circ}$ & $7^{\circ}$ & $8^{\circ}$ & $9^{\circ}$ & - \\
\hline & adequados ao que se & & & & & & I & & & & & & I \\
\hline & propõe pelo Currículo & & & & & $\mathrm{X}$ & $\mathrm{R}$ & & & & & $\mathrm{X}$ & $\mathrm{R}$ \\
\hline 3 & $\begin{array}{l}\text { Referência de Geografia } \\
\text { do Estado de Goiás e } \\
\text { quanto as expectativas } \\
\text { que se esperam alcançar } \\
\text { em relação a } \\
\text { aprendizagem? }\end{array}$ & & $\mathrm{X}$ & $\mathrm{X}$ & $\mathrm{X}$ & & $\mathrm{S}$ & & $\mathrm{X}$ & $\mathrm{X}$ & $\mathrm{X}$ & & $\mathrm{S}$ \\
\hline & A qualidade e & & & & SIM & & & & & & SIM & & \\
\hline & $\begin{array}{l}\text { quantidade dos } \\
\text { conteúdos climáticos }\end{array}$ & NÃO & $6^{\circ}$ & $7^{\circ}$ & $8^{\circ}$ & $9^{\circ}$ & - & NÃO & $6^{\circ}$ & $\begin{array}{l}7 \\
\\
\circ\end{array}$ & $8^{\circ}$ & $9^{\circ}$ & - \\
\hline 4 & abordados são & & & & & & I & & & & & & I \\
\hline 4 & adequadas as & & & & $\mathrm{X}$ & $\mathrm{X}$ & $\mathrm{R}$ & & & & $\mathrm{X}$ & $\mathrm{X}$ & $\mathrm{R}$ \\
\hline & $\begin{array}{l}\text { finalidades do ensino da } \\
\text { Geografia no Ensino } \\
\text { Fundamental? }\end{array}$ & & $\mathrm{X}$ & $\mathrm{X}$ & & & $\mathrm{S}$ & & $\mathrm{X}$ & $\mathrm{X}$ & & & $\mathrm{S}$ \\
\hline & Existe integração entre & NãO & & & SIM & & & NÃO & & & SIM & & \\
\hline & os temas da obra tal que & NAO & $6^{\circ}$ & $7^{\circ}$ & $8^{\circ}$ & $9^{\circ}$ & - & NAO & $6^{\circ}$ & $7^{\circ}$ & $8^{\circ}$ & $9^{\circ}$ & - \\
\hline & possibilita ao aluno & & & & & & I & & $\mathrm{X}$ & $\mathrm{X}$ & $\mathrm{X}$ & $\mathrm{X}$ & $\mathrm{I}$ \\
\hline 5 & relacionar os conteúdos & & $\mathrm{X}$ & $\mathrm{X}$ & $\mathrm{X}$ & $\mathrm{X}$ & $\mathrm{R}$ & & & & & & $\mathrm{R}$ \\
\hline & $\begin{array}{l}\text { já estudados e outros } \\
\text { conhecimentos com a } \\
\text { temática climática? }\end{array}$ & & & & & & $\mathrm{S}$ & & & & & & $\mathrm{S}$ \\
\hline & & NÃ & & & SIM & & & Nก̃ & & & SIM & & \\
\hline & E satisfatória a & NAU & $6^{\circ}$ & $7^{\circ}$ & $8^{\circ}$ & $9^{\circ}$ & - & NAU & $6^{\circ}$ & $7^{\circ}$ & $8^{\circ}$ & $9^{\circ}$ & - \\
\hline 6 & $\begin{array}{l}\text { aboraagem do invro } \\
\text { didático pelo que é }\end{array}$ & & & & & & I & & & & & & I \\
\hline & previsto nelo PCN? & & & & & & $\mathrm{R}$ & & & & & & $\mathrm{R}$ \\
\hline & & & $\mathrm{X}$ & $\mathrm{X}$ & $\mathrm{X}$ & $\mathrm{X}$ & S & & $\mathrm{X}$ & $\mathrm{X}$ & $\mathrm{X}$ & $\mathrm{X}$ & $\mathrm{S}$ \\
\hline & & NãO & & & SIM & & & NÃO & & & SIM & & \\
\hline & A obra está adequada a & NAO & $6^{\circ}$ & $7^{\circ}$ & $8^{\circ}$ & $9^{\circ}$ & - & NAO & $6^{\circ}$ & $7^{\circ}$ & $8^{\circ}$ & $9^{\circ}$ & - \\
\hline 7 & concepção de Geografia & & & & & & $\mathrm{I}$ & & & & & & I \\
\hline & escolar? & & & & & & $\mathrm{R}$ & & & & & & $\mathrm{R}$ \\
\hline & & & $\mathrm{X}$ & $\mathrm{X}$ & $\mathrm{X}$ & $\mathrm{X}$ & $\mathrm{S}$ & & $\mathrm{X}$ & $\mathrm{X}$ & $\mathrm{X}$ & $\mathrm{X}$ & $\mathrm{S}$ \\
\hline & Legenda: & INSA & FAT & RIO & $\mathrm{R}-1$ & EGUI & $\mathrm{R}$ & ATI & ATÓF & & & & \\
\hline
\end{tabular}

FONTE: Autoria própria.

Observando os dados obtidos com a análise, num contexto geral é notório que alguns elementos utilizados e inseridos ao longo dos volumes de cada Coleção contribuem para que as mesmas sejam recomendadas no ensino da Geografia, como a coesão, coerência e a estrutura que os volumes apresentam.

É importante ressaltar que tais características contribuem assim, para outros aspectos considerados de maior relevância para a aprendizagem do aluno, tendo em vista que o conjunto dos elementos combinados 
entre si é que possibilitam que o todo consiga atingir seus objetivos, ou seja, não basta que determinado conteúdo seja ensinado em dada Unidade, priorizando apenas o conhecimento que será exposto, o autor deve proporcionar ao aluno condições textuais e estruturais suficientes para que o mesmo consiga fazer uma apreensão integrada dos conteúdos expostos na obra, o que pode ser alcançado com a utilização das Coleções analisadas.

Quanto à qualidade dos conteúdos, convém destacar que no decorrer das Unidades em que são trabalhados os conhecimentos climáticos, a integração dos conteúdos ocorre apenas com base nos conteúdos estudados nos capítulos anteriores dentro da mesma Unidade na coleção onde há essa integração, ou seja, na Coleção Jornadas.geo, tendo em vista que na Coleção Projeto Araribá não ocorre qualquer integração dentro desta perspectiva.

Pode-se ainda indagar que algumas das notas complementares empregadas nos capítulos dos livros didáticos remetem a integração, porém, essa integração não ocorre com os conteúdos estudados na mesma obra e sim com outros materiais complementares, como sites e outras obras que talvez nem sempre sejam acessíveis ao aluno e por muitas das vezes podem passar despercebidas.

Em ambas as Coleções, há adequação do que é abordado em relação ao que propõe o PCN e na maioria dos casos pelo Currículo Referência de Geografia do Estado de Goiás. O que pode ser notado é que no PCN ressalta-se o desenvolvimento das habilidades dos alunos dentro dos vários saberes geográficos, não se priorizando apenas uma habilidade em especial, como no Currículo Referência, que enfatiza independente do conteúdo estudado apenas as habilidades cartográficas.

Sobre os conteúdos e conceitos climáticos abordados em ambas as Coleções, é possível perceber que os mesmos dão subsídios para que o aluno adquira os conhecimentos climáticos pertinentes ao que se é proposto para o Ensino Fundamental.

Os livros didáticos aqui analisados oferecem suporte para que o aluno desenvolva o pensamento crítico da realidade quando se é trabalhada a temática do Clima. Todavia, algumas observações se fazem necessárias como: a Coleção Jornadas.geo leva o aluno ao desenvolvimento do pensamento crítico da realidade através de questionamentos e indagações presentes, principalmente nas páginas capitulares, notas complementares que fazem menção as ilustrações utilizadas e das sessões de exercícios. A Coleção Projeto Araribá de modo análogo, ao exposto anteriormente, os volumes dessa Coleção têm capacidade de levar o aluno ao pensamento crítico da realidade, por meio apenas de notas complementares e questionamentos levantados na página de introdução a Unidade, porém, em quantidade mínima se considerada a Coleção anterior.

Segundo Costa (2003) e Nitahara (2015), atualmente, muitas são as discussões que permeiam o âmbito educacional quando se trata da qualidade do ensino básico, discussões essas que giram em torno da problemática qualidade vs. quantidade dos conteúdos. Observando os conteúdos delimitados pelo Currículo Referência da Rede Estadual de Educação de Goiás a serem estudados no $6^{\circ}, 7^{\circ}, 8^{\circ}$ e $9^{\circ}$ ano do Ensino Fundamental, é notório quanto aos conhecimentos climáticos da Coleção Jornadas.geo que há qualidade no que tange aos conhecimentos abordados, uma vez que são de fácil entendimento e se prioriza apenas o julgado essencial para o aprendizado do aluno.

O PCN (1998), reconhece que muitos são os temas que podem ser trabalhados no ensino da Geografia no terceiro ciclo do Ensino Fundamental, que podem ser desenvolvidos através de quatro eixos temáticos. Dentre esses eixos, cabe aqui ressaltar o que se propõe no eixo temático 2, que debate sobre o estudo da natureza e sua importância para o homem.

Através dos conhecimentos adquiridos por meio dos ciclos anteriores se destaca conhecimentos importantes para que o aluno possa discutir sobre os mecanismos climáticos, tais como: massas de ar, variações de áreas de tipos de tempos atmosféricos, dinâmica do tempo atmosférico, manifestação dos fenômenos naturais, leis naturais que regulam esses fenômenos, Clima do Brasil, circulação atmosférica e estações do ano, o Clima no cotidiano das pessoas, as cidades e as alterações climáticas, as florestas e sua interação com o Clima e previsão do tempo e Clima (BRASIL, 1998). Nesse sentido, é perceptível que os componentes delimitados pelo PCN para a compreensão da temática conhecimentos climáticos vai de encontro aos conteúdos explanados nos livros didáticos abordados.

O Currículo Referência de Geografia do Estado de Goiás estabelece através de suas diretrizes algumas reflexões sobre tal ciência e sobre seu atual ensino, com vista a priorizar a relevância da formação e capacitação dos estudantes, e dar bases aos professores quanto ao entendimento acerca das categorias de análise e dos conteúdos definidos como essenciais para o processo de ensino através dos eixos temáticos: Físico Territorial, Social e Cartográfico. 
De forma geral, as obras analisadas contribuem para o processo de construção e desenvolvimento do pensamento crítico do aluno, em especial quando se remete a sua junção com a realidade do estudante, aspecto esse que pode ser considerado um dos principais fatores que merecem destaque no processo de ensino atualmente, não só no ensino da Geografia, bem como de outras disciplinas.

\section{CONSIDERAÇÕES FINAIS}

No âmbito educacional, não somente o que se é ensinado torna-se relevante, outros aspectos aí inseridos também merecem destaque, como as metodologias de ensino, que são as peças-chave orientadoras das práticas educativas.

A pesquisa permitiu reconhecer através da análise das coleções selecionadas, o modo como os conteúdos que remetem aos conhecimentos climáticos são expostos, juntamente com os demais aspectos que compõem cada obra, que levam o aluno ao desenvolvimento do pensamento crítico e integrado da realidade.

Deve-se ressaltar também que o livro didático ainda é o principal instrumento pedagógico utilizado durante as aulas, o que evidencia como sua abordagem em relação a determinada temática acaba por influenciar na apreensão dos conteúdos e sua integração com o mundo vivido pelo aluno. Cabe ao professor conhecer e analisar os livros que irá usar para ministrar sua disciplina, observando as características da realidade de seu público-alvo.

\section{REFERÊNCIAS}

[1] BRASIL. Secretaria de Educação Fundamental. Parâmetros curriculares nacionais: Geografia. Brasília: MEC/SEF, 1998. 156p. Disponível em: <http://portal.mec.gov.br/seb/arquivos/pdf/geografia.pdf>. Acesso em: 18 maio 2015.

[2] COSTA, Giovânia. Educação: Qualidade x Quantidade (Educar-se é aprender a pensar). 2003. Disponível em: <http://www.educacaopublica.rj.gov.br/biblioteca/educacao/0037.html>. Acesso em 25 set. 2015.

[3] MATIAS, Vandeir Robson da silva. As relações entre sociedade e natureza e os problemas socioambientais a partir da disciplina climatologia do curso técnico em meio ambiente do CEFET-MG. 2004. Disponível em: <http://www.senept.cefetmg.br/galerias/Arquivos_senept/anais/terca_tema4/TerxaTema4Artigo6.pdf>. Acesso em 25 set. 2015.

[4] MENDONÇA, Francisco; DANNI-OLIVEIRA, Inês Moresco. Climatologia: Noções básicas e climas do Brasil. São Paulo: Oficina de Textos, 2007. 206p.

[5] NITAHARA, Akemi. Educadores defendem menos conteúdo e mais qualidade no Ensino Básico. 2015. Disponível em: <http://www.ebc.com.br/educacao/2015/09/educadores-defendem-menos-conteudo-e-maisqualidade-no-ensino-basico>. Acesso em 27 set. 2015.

[6] SOUZA, Malu Ítala Araújo; OLIVEIRA, Adriana Olivia Sposito Alves. A mini-estação meteorológica como estratégia de ensino para apropriação de conhecimentos climáticos. IESA/UFG, 2012. 


\section{Capítulo 5}

Geografia, gabinete e empiria: Um estudo sobre as potencialidades do trabalho de campo - Apreciações de uma festividade católica

\section{Luís Ricardo Soares Wenceslau}

Emerson Costa de Melo

Jeferson José de Oliveira Pinheiro

Resumo: 0 presente artigo coloca em evidência a relevância do uso e aplicabilidade do trabalho de campo como uma ferramenta essencial para a realização da pesquisa geográfica. Logo, o texto apresenta um breve histórico sobre as origens do trabalho de campo na Ciência Geográfica e, sinaliza alguns aspectos de sua descaracterização ao longo dos tempos. Entretanto, com objetivo de fazer luz a questão proposta, ressalta-se a aplicabilidade e relevância do trabalho de campo, por meio da descrição de experiências - orientadas pelos pressupostos investigativos do método fenomenológico - durante a organização e celebração da quadragésima Festa do Jubileu de Santa Luzia, na cidade de Carangola-MG

Palavras-Chave: Trabalho de campo; Geografia; Método Fenomenológico; Jubileu de Santa-Luzia. 


\section{INTRODUÇÃO}

0 presente trabalho tem como objetivo apresentar uma discussão sobre as potencialidades do trabalho de campo para realização do exercício geográfico. Neste sentido, o debate procura tomar como base os desafios empregados na realização dessa prática a fim de auxiliar os geógrafos a retomarem o seu uso na contemporaneidade, principalmente, no que se refere aos estudos sobre a relação entre sujeito e lugar a partir de experimentações afetivas. Para tanto, a partir de um recorte espacial específico e de uma experiência prática, surgiu a necessidade de apresentar como base norteadora de utilização dessa ferramenta, a investigação da quadragésima festa do Jubileu de Santa Luzia na cidade de Carangola-MG. A escolha desse evento justifica-se pela notoriedade que o trabalho de campo ganhou na sistematização do festejo, apresentando processos metodológicos capazes de instruir pesquisadores em suas pesquisas.

O tema proposto torna-se de suma importância, uma vez que o trabalho de campo foi sendo descaracterizado ao longo da história do pensamento geográfico. Além disso, mesmo com o surgimento de novos paradigmas epistemológicos e de novas produções teóricas, notou-se que as pesquisas de cunho norteador - que auxiliam no uso adequado da ferramenta - não avançaram, ficando por muito tempo restritas às publicações clássicas da Associação de Geógrafos Brasileiros e seu Boletim Paulista de Geografia (no 84, 2006), necessitando de estudos mais atualizados. Assim sendo, apesar da imensurável contribuição dessa base teórica, faz-se preciso avançar, pois segundo Suertegaray (2002) "a pesquisa de campo é um tema muito importante na Geografia, porém, com pequena discussão" (p. 92), sobretudo na contemporaneidade.

Ressalta-se que todo processo de transição temporal promove uma restruturação do espaço geográfico. Esses movimentos históricos fazem com que a compreensão profunda das relações sócio-espaciais tornem-se ainda mais complicadas para os geógrafos, principalmente sem pesquisas práticas. Essa tarefa apresenta-se ainda mais complexa porque os processos de consolidação do capitalismo e da globalização (SANTOS, 1996) reestruturaram o cotidiano de indivíduos e instituições, colocando a esses profissionais a demanda de explicarem fenômenos com múltiplosterritórios e/ou múltiplasterritorialidades (HAESBAERT, 2019)

Sob as influências dos fenômenos supracitados e com a ascensão do paradigma Humanístico principalmente nos estudos da Geografia Cultural pós anos 80 -, as discussões acerca das potencialidades do trabalho de campo voltam a adquirir relevância na ciência geográfica, pois essas correntes passaram a concentrar suas análises na relação entre aspirações subjetivas e modificação espacial. Diante disso, os profissionais da área retomam a utilização do campo como ferramenta analítica, entendendo-o como um ótimo suporte para o entendimento da realidade. 0 uso desse instrumento passa então a se dar pela sistematização pratica-teórica, pois acredita-se que a reflexão sobre um fenômeno é melhor compreendida quando se verifica a partir da empiria a veracidade da hipótese.

A partir dessa nova concepção de Geografia, ocorre o retorno da valorização do trabalho de campo. Com isso, vários estudos passam a apresentá-lo em suas análises como ferramenta metodológica operacional, porém, muitas vezes, nessas pesquisas esse instrumento aparece apenas no processo descritivo de campo e não como base teórica norteadora para leitores e/ou pesquisadores que desejam utilizar dessa ferramenta nas suas pesquisas. Pensando nisso, esse artigo tem como objetivo não apenas apontar as potencialidades do trabalho de campo para Geografia, mas também de ampliar os debates de instrução para aqueles geógrafos que desejam utilizá-lo na contemporaneidade.

Decerto, acredita-se que essa sistematização promoverá uma maior valorização do trabalho de campo enquanto ferramenta de compreensão da realidade, pois centraliza o debate a partir da um método científico que "apresenta-se tal como leis e categorias, que estão historicamente relacionados, à procedimentos específicos e teorias disseminadas pela comunidade científica" (SPOSITO, 2004 p. 25). Além disso, propiciará novas áreas de pesquisa, pois serão analisados aspectos mais contemporâneos e que foram pouco abordados nos estudos sobre esse instrumento de análise da realidade, isto é, uma festividade católica em uma pequena cidade, evento que possui especificidades socioespaciais possíveis de descobrir estando apenas inserido fora do gabinete.

Visando atender o objetivo proposto, o presente trabalho será discorrido a partir de três temáticas gerais e capítulos específicos: 2) A trajetória do uso do trabalho de campo na ciência geográfica: nos meandros de uma banalização; 3) 0 retorno ao debate: o trabalho de campo na Geografia Humanística e na Geografia Cultural; 4) Processos metodológicos empregados na análise de campo: notas de uma experimentação. 
Ressalta-se que essa estrutura se dá para que o leitor possa situar-se sobre a história do trabalho de campo, suas problemáticas de aplicação e banalizações paradigmáticas, bem como o momento em que acreditamos que essa ferramenta voltou a ser valorizada. Nesse momento, será aprofundado as estratégicas metodológicas que devem servir de base norteadora para novos trabalhos, entendendo que o tema não se esgota aqui. Por fim, para melhor visualização da potencialidade dessa ferramenta, será descrito o passo a passo utilizado em uma pesquisa de campo que visa compreender as territorialidades religiosas da festa do Jubileu de Santa Luzia na cidade de Carangola (MG), estas que, tornam-se inteligíveis profundamente apenas com o contato fenomênico, pois uma hipótese é só uma forma de pensamento, sua existência se dá quando comprovada ou não pela prática.

\section{A TRAJETÓRIA DO USO DO TRABALHO DE CAMPO NA CIÊNCIA GEOGRÁFICA: NOS MEANDROS DE UMA BANALIZAÇÃO}

Desde a antiguidade o trabalho de campo foi utilizado como principal ferramenta de observação e conhecimento do espaço. Tal atividade exerce função significativa desde o período das grandes navegações (séculos XV e XVI), pois os povos europeus já necessitavam lançar-se ao campo para buscar e conhecer terras além-mar. É nesse cenário que naturalistas e viajantes, a partir de experiências e constatações, promoviam a empiria por meio do "frenesi do descobrir um conhecimento do seu mundo circundante, baseado no epiricismo nascido das necessidades políticas e mercantis" (HOLZER, 2001, p.109). Sob tais considerações, acredita-se que a consolidação da Geografia enquanto ciência (século XIX) deve-se muito ao acúmulo de registros trazidos por esses indivíduos.

É válido lembrar que todo conhecimento cientifico nasce da influência da racionalidade humana e pela busca de demonstração da verdade; na ciência geográfica isso não foi diferente. Devido os indivíduos colocarem-se como seres sublimes e superiores, essa disciplina ficou encarregada, inicialmente, em analisar apenas os espaços naturais, visto que o racionalismo promovia uma ideia de fragmentação, como se os seres humanos estivessem acima de qualquer fenômeno, devendo apenas explicá-los de forma externa sem se colocar como participante dos processos espaciais.

Essa fase inicial de estudos espaciais passa a ser chamada de Geografia Tradicional. Nessa época, o trabalho de campo baseava-se na ideia de que o "objeto está posicionado a montante, influenciando o pesquisador e os seus conhecimentos, mesmo que a neutralidade seja um pressuposto básico" (SPOSITO, 2004, p. 34). Em outras palavras, o homem colocava-se como externo a natureza; um ser capaz de sistematizar o espaço/mundo e produzir estudos fidedignos, mesmo sem considerar sua participação no processo de modificação do espaço.

À vista disso, nas primeiras décadas da ciência geográfica - realizados pós institucionalização no século XIX -, os estudos concentravam-se em análises destituídas de valor crítico, pois enfocavam apenas na descrição exaustiva da paisagem vernacular, existente apenas como funcionalidade, sendo "incapaz" de esclarecer a dinâmica dos comportamentos humanos e sua influência na modificação socioespaciais. Diante dessas influências, nota-se que nos primórdios da Geografia o trabalho de campo que deveria ser parte fundamental do método vai aos poucos transformando-se no próprio método, isto é, se o homem considera-se um ser dotado de conhecimento, logo, toda descrição da realidade é levada a condição e critério de verdade.

Essa neutralidade ganhou força no Brasil com a institucionalização (século XIX) da Geografia na Universidade de São Paulo (USP) e como disciplina escolar no Colégio Dom Pedro I em 1837 (ROCHA, 2014). Ambas foram marcadas pelo positivismo descritivo da Geografia Tradicional Francesa, que tinha "conotação quase que enciclopédica, e servia, por isso mesmo, tanto para se referir ao objeto Terra quanto para também denominar os estudos de descrição e representação daquele mesmo objeto" (Ibidem, p. 17). Esses ideais acabavam não permitindo uma reflexão crítica sobre as relações entre homem e meio, tanto nas escolas quanto nas universidades, fatores que impulsionavam um sentimento patriótico de aceitação e amor a nação em qualquer circunstância, pois não se incentivava a reflexão da realidade, nem o contato com ela, apenas estudos teóricos. Tal ideologia positivista passa a perder valor, pois resultava em análises que estão sujeitas a contestação devido as múltiplas particularidades apresentadas aos diversos pesquisadores.

Apesar das falhas de aplicação metodológica do trabalho de campo previsto na Geografia Tradicional, ele apresentou-se como uma importante ferramenta de análise, pois promovia o contato do pesquisador com o espaço. Entretanto, essa relevância passa a ser praticamente desconsiderada quando um novo paradigma ou epistemologia, intitulada Geografia Teorética-Quantitativa, se estabelece na contestação ao 
método hipotético-dedutivo ou empírico, "sob o argumento de que as tecnologias da informação e os modelos matemáticos seriam instrumentos mais adequados para a investigação da realidade" (ALENTEJANO; ROCHA-LEÃO, 2006, p.55).

A exemplo disso, podemos citar o surgimento do Instituto Brasileiro de Geografia e Estatística (IBGE) em 1937 no Governo Getúlio Vargas, estando intimamente ligado aos interesses do Estado na época. Decerto, não se pode contestar o grande aparato da tecnologia na interpretação da realidade, mas apontar para problemática de ter que aceitar "[...] dados provenientes de pesquisas institucionais, [...] que se revelam incompatíveis com as questões de pesquisa" (SERPA, 2006, p.14), tratando, na maioria das vezes, aspectos sociais, políticos, econômicos e culturais de maneira reducionista.

Criou-se um paradoxo em que a razão é obscurecida por ela mesma, pela mitificação da técnica. Por isso, torna-se necessário que o cientista seja muito criterioso na escolha das técnicas que utilizará e que esteja atento para que seus critérios não se esvaeçam diante da sedução da tecnologia (VENTURINI, 2006, p.72)

Por volta de 1960 e 1970, surge a chamada Geografia Crítica ou Radical, epistemologia que corrobora com a noção de movimento histórico de refutação do senso comum e dos modelos cartesianos que propunham o discurso de neutralidade científica. Nesse momento, as relações sociais começam a despertar mundialmente o interesse de diversos geógrafos por estarem no centro de disputas espaciais, porém deuse mais atenção às influências econômicas, negligenciando os aspectos culturais por muito tempo, sendo qualificados como senso comum incapazes de serem considerados como ciência ou fato concreto (ROSENDAHL; CORRÊA, 2014).

Essa epistemologia surge com base no materialismo histórico dialético tendo como maior expoente Karl Marx. Segundo seus ensinamentos, para entender a realidade seria necessário a "confrontação de tese e antítese, a síntese contém aspectos positivos da tensão anterior, e apresenta-se como estágio superior que, por sua vez, se coloca também como uma nova tese" (SPOSITO, 2004, p. 34). Em outras palavras, sujeito e objeto estariam a todo momento interagindo, possibilitando o entendimento de um fenômeno que emerge da negação ou confrontação de problemáticas ou questões norteadoras levantadas pelo pesquisador ao absorver os fatos históricos.

Essa nova forma de pensamento promoveu de forma indireta uma negação ao trabalho de campo como instrumento de construção do pensamento geográfico, pois no método dialético, "estamos no terreno da informação estruturante e dos dados agregado, com maior tendência à homogeneidade" (SERPA, 2006, p.18), fator que resulta em uma supervalorização da teoria sob a prática, focando em aspectos mais atenuantes na sucessão de momentos históricos, na maioria das vezes, os fenômenos político-econômicos.

Podemos citar como exemplo a teoria da luta de classes, que surge da fragmentação de dois grupos sociais, burgueses e proletários, separação que não leva em consideração, por exemplo, as particularidades subjetivas de cada sujeito, a maneira como os fenômenos de exploração incidem sobre eles, enquadrandoos homogeneamente em grupos com características iguais (ricos x pobres), mesmo possuindo diferenças de gênero, raça, cor, entre outros.

Esse paradigma acabou fomentando a falsa ideia de que a racionalização de gabinete explicaria completamente a realidade a partir da confrontação de dados históricos. Embora a dialética tenha contribuído muito para a compreensão da realidade nesse período, ela legitimou uma desvalorização da prática de campo, operacionalização que, ao nosso ver, auxiliaria muito para o entendimento profundo das relações socioespaciais, pois existem particularidades que são melhor explicadas por meio do contato com a realidade, tanto pela observação do pesquisador, quanto pelo contato com os sujeitos que estão inseridos nesse espaço de estudo.

Acrescenta-se que quando um pensamento se propõe a combater um ato de dominação social e paradigmática ele não pode se colocar como único capaz de explicar a realidade, pois a realidade pode ser explicada por diversos métodos, e colocar sua teoria como superior e totalitária é provoca novas marginalizações ou ocultamentos. Em outras palavras, "soa estranho constar, mas a insurgência marxista se tornou moda e eventualmente acabou vítima de seu próprio sucesso". (SMITH apud BARTHOLL, 2018, p.45).

Ao seguir cegamente Marx, seus fundadores [...] utilizaram uma metodologia congelada, pecaram por dogmatismos e sobretudo consagraram um erro de interpretação que desgraçadamente perdura ainda hoje (SANTOS, 20002, p.52) 
Sendo assim, pode-se observar que ao longo do tempo houve uma alteração e/ou desapropriação do trabalho de campo enquanto um instrumento de análise a serviço do exercício geográfico. Com as mudanças interpretativas de cada uma das correntes de pensamento - do positivismo para a geografia teorética-quantitativa e dessas para inicial Geografia Crítica - foi disseminado uma maior fragmentação metodológica. Em alguns momentos ocorreram a propagação de estudos de campo sem teoria, em outros uma teorização sem muito contato empírico, fatores que também resultaram no distanciamento entre aspectos físicos e socioculturais, união que deveria existir, pois é base do pensamento geográfico e resulta em uma melhor compreensão da realidade.

Evidentemente, vários conceitos e técnicas importantes surgiram nesse período, dentre eles: meio circundante, mais-valia, renda absoluta, mercadoria, além dos complexos recursos e técnicas cartográficos digitais. Entretanto, mesmo os geógrafos produzindo estudos mais específicos, seja sobre a espacialidade física ou humana, qualquer método é melhor compreendido através da união entre teoria e prática, agregando conteúdos e não fragmentando-os, visto que um não se explica sem o outro. Em suma, nota-se que são poucas as abordagens que propunham a romper com as dicotomias e entender a organização socioespacial mediante o imaginário de seus sujeitos de transformação, lidando na maior parte das vezes com o fenômeno pronto e "acabado", fomentando numa perda de geograficidade nas pesquisas.

Ressalta-se que a discussão proposta não busca propagar um método privilegiado, até porque "existem tantas Geografias quanto forem os posicionamentos sociais" (MORAES, 1997, p. 30). Nesse sentido, orienta-se que a desarticulação de teoria e prática foi o que, ao nosso ver, promoveu a crise científica e paradigmática da Geografia até esse momento histórico, sobretudo, no que se refere, ao emprego do trabalho de campo, importante instrumento de análise do espaço que passa a adquirir novamente valor apenas com o surgimento da chamada Geografia Humanística e mais fortemente com a Nova Geografia Cultural.

\subsection{O RETORNO AO DEBATE: O TRABALHO DE CAMPO NA GEOGRAFia huMANÍSTiCA E NA GEOGRAFIA CULTURAL}

Para referenciar a proposta anterior, nós direcionamos a discorrer sobre o papel da Geografia Humanística, no que se refere há uma valorização ao trabalho de campo. 0 que essa corrente de pensamento colaborou para essa prática tradicional de ser fazer Geografia? Podemos salientar, a priori, que esse movimento surge em oposição a lógica mecanicista/reducionista de considerar o homem e sua condição espacial. Ressalta-se, então, que é preciso considerar as influências antes e depois de 1970, pois os trabalhos vão ter um enfoque na relação do homem e seu meio; por isso, a paisagem natural aparece como foco da análise, na qual suas modificações estariam ligadas as questões culturais. Nesse momento, o historicismo ainda preponderava e as dinâmicas urbano-industriais não eram evidentes nos estudos, muito menos nas relações simbólicas, morais ou identitárias, já que buscava-se entender apenas o modo de vida no sentido de adaptação.

A partir do final da década de 1980, a Geografia Cultural passou por um processo de renovação; os saberes produzidos não foram descartados, mas outros tipos de análises foram acrescentadas. Com a chamada "virada cultural", marcada por "mudanças na esfera econômica, [...] a a crescente consciência da necessidade de novos modos de se construir e entender a realidade, até então calcada no racionalismo moderno, no raciocínio científico" (MITCHEL, 2000 apud CORRÊA; ROSENDAHL, 2014, p.12), o trabalho de campo passa a ser mais valorizado na ciência geográfica, pois os aspectos culturais tornam-se foco da análise. Nesses caminhos podem ser considerados "tanto a dimensão material da cultura quanto a sua dimensão não material, tanto o presente como o passado, [...] tanto os aspectos concebidos como vivenciados" (CORRÊA; ROSENDAHL, 2014, p.13).

Assim sendo, observa-se que as abordagens humanísticas e culturais diferem muito daquelas que a precederam, pois seus especialistas não descartam as experiências e nem refutam a teoria, visto que estão dedicados a entender os sentidos ocultos da Terra que, por sua vez, apresentam-se nas relações sociais e em um espaço específico, isto é, pela "dimensão subjetiva e a experiência vivida pelo indivíduo e os grupos sociais” (ROSENDAHL, 2002, p.23). Com isso, o interesse do geógrafo vai sendo ampliado para explicação mais profunda da realidade, tentando evidenciar as relações indissociáveis de homem e natureza. Portanto, as pesquisas passam a permitir um contato maior com a realidade, visto que quem explica melhor os fenômenos sócio-espaciais são aqueles sujeitos que estão se apropriando sobre a realidade.

Diante do paradigma cultural, a intuição vai sendo apropriada pela ciência, isto é, as análises empíricas passam a ser mediadas por métodos e construções teóricas. Com isso, ocorre a conexão entre senso 
comum e ciência, no qual o sujeito é quem descreve o objeto e suas relações a partir do seu ponto de vista, depois de se apropriar intelectualmente (SPOSITO, 2004), porque "as essências só podem ser vistas a partir da experiência do fato e o fato só pode ser tratado considerando se a visão das essências" (HOLZER, 2001, p.115). Deste modo, acredita-se que essa corrente de pensamento e sua atualização ou restruturação são responsáveis pela retomada da valorização do trabalho de campo na Geografia.

Diante dos apontamentos, foi possível observar que os processos, que de alguma forma banalizaram o uso do trabalho de campo no exercício geográfico, acabam sendo ressignificados com o paradigma humanístico e cultural, fatores que promoveram a ascensão dessa ferramenta na contemporaneidade, visto a dificuldade de entender as fluidas relações sócio-espaciais. A partir disso, torna-se tarefa dos geógrafos recolocar o debate em um patamar teórico que nos permita entendê-lo como "um momento ímpar na produção de conhecimento alternativo, mediatizado através de uma prática teoricamente orientada, momento consagrador do exercício da prática teórica" (THOMAZ Jr apud ALENTEJANO, 2006, p.57).

Em suma, a Geografia Humanística e a Geografia Cultural mostram-nos que o distanciamento do pesquisador da prática não fomenta análises profundas da realidade. Afirma-se que para a empiria ser bem-sucedida é preciso de uma teorização prévia, a fim de que o geógrafo possa validar ou não seus estudos a partir da comprovação de hipóteses por meio dos fatos. Cabe afirmar que esse novo paradigma nos ensina que o trabalho de campo é uma potencial ferramenta para a compreensão dos fenômenos socioespaciais, mas para que as análises sejam bem-sucedidas é necessário que "a difícil aliança entre a teoria e a prática instrumental tem de ser perseguida e sempre alicerçada na pesquisa de campo" (ALENTEJANO, 2006. p. 55), pois "a primeira depende da segunda na medida em que a prática é fundamento da teoria, já que determina o horizonte de desenvolvimento e progresso do conhecimento" (VAZQUEZ apud BARTHOLL, 2018, p.43). Dessa forma, é necessário que o geógrafo tome consciência de que não deve-se "ir 'à pesquisa' como quem vai ao zoológico ou ao safári! " (KAISER, 1985p.100), isto é, para conhecer um fenômeno devemos olhar com profundidade, munidos da teoria, para observar, sobretudo, aquilo que não havíamos considerado anteriormente.

\subsection{PROCESSOS METODOLÓGICOS EMPREGAdOS NA ANÁLISE DE CAMPO: NOTAS DE UMA EXPERIMENTAÇÃO}

Conforme foi abordado nos itens anteriores, todo o processo de construção da Geografia enquanto ciência passou por uma descaracterização em relação a apreensão das relações vividas, da relação indissociável de homem-natureza. Atenta-se que devido a tal questão, o uso do trabalho de campo passou a ser desvalorizado devido, inicialmente, ao seu caráter não científico e, posteriormente, ao seu desuso nas pesquisas de gabinete. Essa problemática, porém, perdeu força com o surgimento dos paradigmas humanísticos e culturais que, de certa forma, trouxeram a valorização novamente dessa ferramenta metodológica aos estudos geográficos.

Diante das novas formas de pensamentos supracitadas, visualizou-se, também, os devidos cuidados que devem ser utilizados para que o geógrafo atinja seu objetivo a partir do uso do trabalho de campo. Pensando em uma melhor visualização das potencialidades dessa ferramenta será discorrido no próximo capítulo uma experiência de aplicação prática da empiria, baseada nos estudos da Geografia Cultural e da Geografia da Religião. Mais especificamente, será apresentado as contribuições de um estudo de caso realizado na festa de Santa Luzia na cidade de Carangola-MG.

Situado na Zona da Mata de Minas Gerais, na confluência com os Estados de Minas Gerais, Rio de Janeiro e Espírito Santo, o município Carangola possui, segundo o censo do IBGE (2017), 33.559 pessoas, dentre as quais 20.453 são católicos. A escolha de sua padroeira surge em meio a um cenário político-cultural caótico, mas a afirmação de sua imagem foi criada 1977 em torno de sua festividade, da construção de uma identidade própria que apresenta-se, como bem afirma Mathias Le Bossé (2013), a partir de "perspectivas diferentes, e que podem incluir igualmente aspectos de ordem física ou psíquica, material ou intelectual. [..]. Se exprime e se comunica de maneira interna e externa, por meio de práticas simbólicas e discursivas". (p.233). Assim sendo, surgiu a ideia de compreender a importância desse festejo na vida dos participantes e da cidade, além de sua influência no remodelamento do espaço a partir das variadas territorialidades.

Antes de iniciar a descrição, salienta-se aqui que o Jubileu de Santa Luzia apresenta atores e espectadores, porém, um dá sentido ao outro, mas estes são afetados de forma distinta, pois os primeiros promovem a organização e os últimos lhes dão o significado. 0 evento supracitado ocorre anualmente do dia quatro a 
treze de dezembro, entretanto, seus preparativos e/ou influências antecedem essa data, visto que serão nove dias de celebrações e os convidados precisam ser acomodados no espaço para participarem de todos as atividades.

Nesse ínterim, a análise da festa delineia-se sob os auspícios do método fenomenológico e operacionalizase pelo trabalho de campo, pois acredita-se que as formas de cultura "no curso da história, devem ser apreendidas através da experiência íntima de um sujeito; que cada produção espiritual é somente o reflexo de uma cosmovisão" (SPOSITO, 2004, p.35), já que o espaço onde se materializa uma cultura é "a base sobre o qual se estabelecem 'mapas de significados', uma expressão que denota a diferenciação simbólica do espaço” (CORREA, 2012, p.137). Nesse processo, os significados são considerados instáveis, caracterizados pela "polivocalidade", isto é, para cada grupo pode haver significados distintos para os mesmos processos e fenômenos (Ibidem, p.134).

Dessa maneira, faz-se importante salientar ao leitor que o processo investigativo dos resultados obtidos na sistematização da festa foi dividido em três momentos com objetivos específicos, a fim de demonstrar a importância que o trabalho de campo mediado pela teoria foi capaz de promover. Considera-se: no primeiro momento, o período de elaboração do campo, da construção teórica acerca do fenômeno a ser estudado. No segundo, as dinâmicas que antecedem o festejo, o estudo sobre os preparativos para o Jubileu; no terceiro, é descrito a análise das primeiras atividades culturais; e, por fim, o ápice do estudo, a festa, que "enseja a constituição de territorialidades que delineiam o território - um território encarnador da cultura". (CORREA, 2013, p.207). Acredita-se que essa divisão auxiliará aos leitores entenderem todo o processo investigativo da festa e como o trabalho de campo auxiliou no desenvolvimento da pesquisa.

\subsubsection{PRIMEIRO MOMENTO: ANÁLISE HISTÓRICA DO FENÔMENO}

No primeiro momento foi necessário entender os aspectos geohistóricos envolvidos na consolidação da Igreja enquanto matriz da cidade e os fatores que proporcionaram a escolha de Santa Luzia como padroeira. Atrelado a isso, tornou-se de suma importância debruçar-se sobre leituras que tratam da temática cultural e festiva na Geografia, visto à busca de compreender as influências do evento no remodelamento do espaço e seus impactos na vida dos participantes. Essa relação entre história local e Geografia teve de ser realizada para que o trabalho não se tornasse apenas de cunho historiográfico.

Baseados nessa perspectiva, fez-se em primeira instância uma pesquisa de cunho bibliográfico no acervo da Igreja - por meio do livro tombo3, além das entrevistas abertas com o pároco, buscando entender um pouco mais sobre religiosidade da cidade. Infere-se a isso que a história não é apenas uma sucessão de acontecimentos, mas também uma reconstrução de uma memória que ainda influencia na vida das pessoas, mesmo que isso não signifique que a identidade não se alterou ou reestruturou-se.

Portanto, foi possível descobrir que a relação entre santa e cidade não foi especificamente subjetiva ou hierofânica, já que os motivos de construção desta matriz eram de ordem política e não religiosa, pois a "cidade pertencia a Tombos - reduto de conservadores - e por isso a elite resolveu construir a Igreja de Santa Luzia para não assistir missa em Igrejas de partido político contrário”. (CARELLI, 2002, p.210).

Ademais, embora existisse a Igreja de Nossa Senhora do Rosário em Carangola, sua população não estava satisfeita, evidenciando também aspectos de ordem racial, pois a ermida era de devoção aos povos negros escravizados da época e os brancos não se submeteriam a essa prática.

A partir de tais constatações, salientamos que uma boa construção teórica precede a prática, pois se o pesquisador vai a campo sem essa confrontação prévia, ele deixa de entender uma série de fatores que modelaram a história e o comportamento da cidade. Esses aspectos evidenciaram que a festa nessa cidade não é apenas "reavivamento sistemático de um passado específico em uma temporalidade" (GIL FILHO, 2008, p.70), mas uma busca de autolegitimação de ideais morais e hegemônicos.

Munidos agora com um conhecimento epistemológico atrelado ao historiográfico local, a operacionalização da pesquisa de campo pode ser executada. Ela foi desenvolvida por meio de entrevistas semiestruturadas e abertas. Salientamos que: "[...]a única maneira de garantir que este depoimento seja verdadeiro é conquistando a confiança dos sujeitos da pesquisa. [...] (MARCOS, 2006. p. 114). Seguindo essa perspectiva, foi realizada com intensa interação entre os participantes do festejo, que revelaram suas experiências geográficas de apropriação

\footnotetext{
30 livro tombo é uma ferramenta essencial para compreensão histórica de uma paróquia, pois relatam festejos, cartas pastorais, algumas intervenções políticas e ou administrativas que influenciaram na vida religiosa da cidade.
} 


\subsubsection{SEGUNDO MOMENTO: IDAS E VINDAS AO CAMPO}

Os primeiros dias no campo deram-se na busca de visualizar os preparativos do festejo, visto que "eventos importantes induzem uma transformação; mesmo que seja visto um recuo ou avanço o território é modificado, aparecendo como o que melhor corresponde à afirmação do poder" (ROSENDAHL, 2012, p.52). Assim sendo, no período que antecede o início do Jubileu, observou-se muita divulgação sobre o cronograma (que já circulava nas ruas, mídias e na rádio local do evento). A Igreja já apresentava muita movimentação e alguns locais passavam a assumir novas características: o estacionamento rotativo situado na lateral do santuário, que em dias normais funciona como renda extra, sede espaço para disposição de mesas, barraquinhas de comidas e rifas que aos poucos vão sendo armadas. Uma das garagens da casa paroquial torna-se ponto de coleta de doações de mantimentos para o fomento da festa, que, a todo momento, os moradores entregavam.

No decorrer do tempo, diversas mercadorias eram entregues por um supermercado local; voluntários vão aparecendo, a confraria vai articulando as demandas, a equipe de manutenção checava a iluminação e o telhado; um mutirão de limpeza era responsável em lavar a Igreja e de copilar mais cadeiras no interior do santuário. Em conversas informais, os organizadores relataram que em todos os anos o público aumenta e que é essa a intenção, fortificar a fé e agregar devotos.

Tudo pronto, passa-se, então, para o início do $40^{\circ}$ Jubileu de Santa Luzia, que versa sobre o aniversário de 151 anos de existência da paróquia. A visita a um espaço sagrado e antes de mais nada uma vivência afetiva. Dessa maneira, a "vida no santo" é viabilizada pela simetria espacial entre construção, organização e função simbólica. 0 espaço sagrado permite o homem a romper com as raízes atávicas do mundo cotidiano, possibilitando ao devoto encontrar um universo livre de imperfeições no qual seus anseios e dúvidas serão desmistificadas no suporte dos ensinamentos e sob as práticas religiosas.

Ressaltamos, novamente, que as idas e vindas ao campo possibilitaram um melhor entendimento sobre o funcionamento da cidade durante o evento. Notou-se que as hipóteses políticas econômicas faziam sentido, pois a festa era organizada nas áreas centrais e de maior poder aquisitivo, afirmando que o passado histórico burguês ainda continuava vivo. Dessa forma, o espaço de festejar "é a síntese projetiva da instância econômica, da instância jurídico-política e da instância cultural-ideológica" (MOREIRA, 2007, p.71), relação que só foi possível de entender, pois houve a união entre teoria e prática. Ademais, o trabalho de campo foi mostrando-se uma ferramenta potencial para a leitura da realidade.

\subsubsection{TERCEIRO MOMENTO: O DESENROLAR DA FESTA}

Depois de todo processo de restruturação espacial, as celebrações têm início. Considera-se, nesse momento, como a preparação espiritual/simbólica para a festa. Esse ato desenvolve-se com as novenas, na ação de fazer e pagar promessas, na qual a Santíssima Trindade (Pai, Filho e Espírito Santo) é invocada para livrar os devotos do pecado, possibilitando a estes serem consagrados com a benção da padroeira no último dia.

Sob tal enfoque, as práticas devocionais constituíram-se por um roteiro preestabelecido e foi possível observar a chegada dos romeiros - modeladores das cidades-santuários no período noturno. São eles que vão dando sentido à festa e promovendo a efervescência do espaço que, por conseguinte, têm como função dar suporte às práticas, funcionando como "mediadora e espelho da sensibilidade cultural" (BONNEMAISON, 2012), um verdadeiro sacra-espaço. Diante disso, considera-se que a paróquia de Santa Luzia apresenta diferenciações simbólicas no período da novena em homenagem à sua padroeira. Ou seja, no vespertino, as missas agregavam em sua maioria idosos, pessoas aposentadas, fomentando pouco povoamento na Igreja, pois a vida no espaço profano capitalista "impedia" a vinda de pessoas antes do fim da jornada de trabalho e/ou estudo.

Outras atividades puderam ser visualizadas durante o trabalho de campo em dias de novena. Destaca-se aqui momentos de irradiação da área de abrangência do Jubileu, marcada pela realização de um leilão, prática que perpetua as raízes rurais da cidade. Essa dinâmica foi pensada em católicos pouco assíduos que podem ser caracterizados como peregrinos renovados, àqueles que não se interessam muito em realizações tradicionais, pois "acreditam que o sagrado já existe dentro deles, em seu self, sem que ele precise estar no lugar sagrado para que ocorra a transcendência" (OLIVEIRA 2011, p.48).

Por meio da empiria, é possível observar que toda a teoria apreendida foi colocada em veracidade na prática. Com isso, foi possível observar o que os estudos contemporâneos da Geografia Cultural vêm 
apontando, ou seja, mesmo com a transição de momentos históricos, fator que possibilitaria um secularismo religioso, observa-se muito mais processos de movimentos contrasecularização no catolicismo. Assim sendo, visando ser flexível ao momento de crise e perda de adeptos, a instituição Católica começa a utilizar formas mais dinâmicas de reforçar sua hegemonia, como é o caso da festa estudada, pois visualizamos práticas que distanciaram-se do espaço fixo e sagrado da Igreja para atingir novos fiéis.

\subsubsection{QUARTO MOMENTO: 0 ÚLTIMO DIA DE CAMPO - A FESTA}

O Jubileu, direciona-se ao seu ápice com o dia da festa e do aniversário da padroeira, uma dinâmica que atenua as diferenciações socioespaciais na cidade de Carangola/MG, que nesse momento estava paralisada pelo feriado municipal em homenagem à Santa Luzia. Esse dia foi marcado pelas peregrinações e sua diversidade de participantes no espaço-tempo. Mesmo os romeiros se homogeneizando enquanto agentes simbólicos e, sendo assim, como aponta Rosendahl (2009), frequentadores de "um dia", esses são muito heterogêneos; suas motivações são variadas e partir do campo e das entrevistas foi possível entender as motivações da ida dos mesmos para a festa.

À vista disso, notou-se que nesse último dia várias manifestações aconteceram, o dinamismo dos eventos apontou para o que Correa (2004) considera ser uma "circularidade cultural", um movimento de trocas de costumes que se dá em diálogo em um mesmo território de articulação. Neste caso, o espaço festivo que está em constante (re)arranjo espacial. Acrescenta-se que não existiam apenas devotos e moradores da cidade, estavam presentes pessoas de vários lugares e com intuitos diferentes, como é o caso dos turistas, dos comerciantes ambulantes, entre outros.

Ressalta-se que o trabalho de campo desenvolvido no Jubileu nos possibilitou, também, a observar o entrelaçar entre duas realidades distintas que, teoricamente e segundo as bibliografias geográficas estudadas, não deveriam se misturar pois detém funções distintas e preestabelecidas. Nota-se que ocorre uma ressignificação do que acreditávamos ao ler as bases de pesquisa da Geografia Cultural, evidenciando novamente as potencialidades da empiria atrelada há um método de pesquisa.

Nesse ínterim, devemos considerar que os espaços sagrados são os quais o sagrado manifesta-se. Imaginase que, para além da materialidade urbana existe um universo simbólico e qualitativamente forte, permeado pelo sobrenatural que permite que o homem "obtenha um 'ponto fixo'; uma orientação na homogeneidade caótica” (ELIADE, 1992, p.18), um estatuto ontológico que explica a existência humana perante a imagem de Deus.

Em contrapartida, a experiência profana mantém a homogeneidade, rege-se pelo caos social que não prevê uma explicação transcendente da vida. Ela funda-se por uma "massa amorfa de uma infinidade de 'lugares', mais ou menos neutros, onde o homem se move, forçado pelas obrigações de toda existência integrada numa sociedade industrial" (ELIADE, 1992, p.18).

Sob tais orientações, ressaltamos que a dinâmica máxima - a procissão de Santa Luzia - último evento do Jubileu, evidenciou mais claramente o entrelaçar entre sagrado e profano, pois sua realização, caracterizada pela multiterritorialidade, permitiu aos participantes "a mobilidade concreta ou virtual, que implica a possibilidade de acessar ou conectar diversos territórios" (SAQUET; SPOSITO, 2009, p. 343). Sendo assim, foi possível observar que a cidade vai se transformando "em 'lugares de memórias' com caráter religioso, outros propriamente profanos e outros ainda reunindo ambos os atributos" (SCOCUGLIA; FARIAS, 2012, p.17).

Em suma, afirmamos que o fundamental foi "compreender a formação de territórios pelas práticas devocionais, as mesmas que constituem as práticas culturais/religiosas que delinearam territorialidades a partir de fronteiras porosas" (CLAVAL, 1999 apud CAXIAS, 2017, p.4). Essas constatações foram possíveis apenas pela apreensão da teoria local, dos estudos da Geografia Cultural e a confrontação empírica de ambas, feita por meio de um método especifico, possibilitando a compreensão mais profunda do evento religioso que nos debruçamos a estudar.

\section{CONSIDERAÇÕES FINAIS}

Conforme fora proposto neste exercício reflexivo, nosso interesse repousou-se sobre a necessidade de compreender a importância do trabalho de campo na Geografia e sua contribuição para a pesquisa geográfica. Com a descrição dos momentos empíricos, procuramos proporcionar uma orientação aos 
geógrafos que desejam utilizar dessa ferramenta metodológica nos seus estudos, isto é, a necessidade de programar e estruturar sua prática por meio da teoria. Isso significa não apenas o movimento em direção ao que pode ser descrito, mas também ao que necessita ser interpretado e representado. Para isso, é necessário estar atento não apenas ao que foi previamente suposto e sim ao que poderá estar posto, já que tudo aquilo que foi teorizado poderá mudar e ser reformulado, pois o espaço geográfico é mutável e necessita de análises que reflitam sobre essas dinâmicas.

Salientamos que a prática por si só não salvará as rupturas e crises dessa ciência, entretanto, caso a sua aplicação seja desenvolvida nos moldes seguidos nessa experimentação prática que foi descrita no último capitulo, o geógrafo conseguirá analisar mais profundamente seu objeto/sujeitos de estudo. Assim sendo, percebeu-se que o trabalho de campo quando atrelado a um bom método, torna-se uma potencial ferramenta de pesquisa para quem pretende entender as organizações socioculturais na atualidade, pois o contato com o outro lhe permite adentrar a um universo único, em que a geograficidade é revelada em um emaranhado de subjetivações.

Mais do que respostas, o propósito desse artigo foi de fazer com que os geógrafos que estão se preparando para desenvolver suas pesquisam repensem sobre sua forma de operacionalização e ferramentas metodológicas utilizadas. Como já foi dito no decorrer do texto, não existe um método privilegiado para refletir sobre o espaço geográfico, o que realmente é necessário é que o profissional estruture suas hipóteses e busque em sua espacialidade a sua veracidade ou não; lembrando que um bom campo se faz de uma constante apreensão teórica prévia. É nesse processo que destacamos o trabalho de campo como potencialidade e que destacamos que essa ferramenta pode ser utilizada não apenas em pesquisas de cunho bibliográfico analítico, mas também nas práticas escolares, propiciando, por exemplo, o entendimento de conceitos não inteligíveis dentro da sala de aula, que não nos cabe discutir aqui pela delimitação do tema. Dessa maneira, reafirmamos que essas contribuições não se esgotam aqui e ficam como incentivo para novos estudos

\section{REFERÊNCIAS}

[1] ALENTEJANO, Paulo Roberto Raposo; Otávio M. ROCHA-LEÂO. Trabalho de Campo: uma ferramenta essencial para os geógrafos ou um instrumento banalizado? In: Boletim Paulista de Geografia, v. 84, p. 51-68, 2006.

[2] BARTHOLL, Timo. Por uma Geografia em Movimento: a ciência como ferramenta de luta. Rio de Janeiro: Consequência, 2018.

[3] BONNEMAISON, J. Viagem em torno do território. In: CORRÊA; ROSENDAHL (coord.) Geografia Cultural: uma antologia (1). Rio de Janeiro: Eduerj, 2012.

[4] CARELLI, Rogério. Efemérides Carangolenses. Viçosa. Editora Folha de Viçosa, 2002.

[5] CAXIAS, D. D.. Viva a São Pedro! A Força da devoção desenhando territórios. In: XII Encontro Nacional da ANPEGE, 2017, Porto Alegre. Anais do XII ENANPEGE, 2017. p. 5791-5801.

[6] CORREA, A. M. Irmandade da Boa Morte como manifestação cultural afro-brasileira: de cultura alternativa a inserção global. 2004. 323 f. Tese (Doutorado em Geografia) - Universidade Federal do Rio de Janeiro, CCMN/PPGG, Rio de Janeiro, 2004.

[7] _Não Acredito em Deuses que não Saibam Dançar": a Festa do Candomblé, Território Encarnador da Cultura. In: ROSENDAHL, Zeny; CORREAA, Roberto Lobato. (Org.). Geografia Cultural: Uma Antologia. 1ed.Rio de Janeiro-RJ: EdUERJ, 2013, v. II, p. 203-218.

[8] CORREA, R. L. A. Espaço e Simbolismo. In: CASTRO, I. EI; GOMES, P. C. C; CORREA, R. L. A (Org.). Olhares Geográficos: modos de ver e viver o espaço. 1ed.Rio de Janeiro: Bertrand Brasil, 2012, v.1, p.133 - 153.

[9] ELLIADE, M. O sagrado e o profano. Tradução de Rogério Fernandes. São Paulo: Martins. Fontes,1992.

[10] GIL FILHO, Sylvio Fausto. Espaço sagrado - estudos em Geografia da religião. 1. ed. Curitiba: IBPEX, 2008. v.

01.

[11] HAESBAERT, R. 0 mito da desterritorialização: do "fim dos territórios" à multiterritorialidade. 11. ed. Rio de Janeiro: Bertrand Brasil, 2019. 396p.

[12] HOLZER, Werther. A Geografia fenomenológica de Eric Dardel,. In: ROSENDAHL, Zenny; CORRÊA, Roberto Lobato (org). Matrizes da Geografia Cultural, Rio de Janeiro: EDUERJ, 2001. p.103-123

[13] IBGE. Carangola. Disponível em: < https://cidades.ibge.gov.br/brasil/mg/carangola/historico>. Acesso em 07 abr 2020. 
[14] KAISER, Bernard. A implicação: um novo sedimento a se explorar na Geografia? In: Boletim Paulista de Geografia, v. 84, p. 25-50, 2006.

[15] MARCOS, V. Trabalho de campo em Geografia: reflexões sobre uma experiência de pesquisa participante. In: Boletim Paulista de Geografia, v. 1 n 84, p. 105-136, 2006.

[16] BOSSÉ, Mathias Le. As Questões de Identidade em Geografia Cultural - algumas concepções contemporâneas. In: ROSENDAHL, Zeny; CORREAA, Roberto Lobato.(Org.). Geografia Cultural: Uma Antologia. 1ed.Rio de Janeiro-RJ: EdUERJ, 2013, v.II, p. 221-232.

[17] MORAES, Antonio Carlos Robert. Geografia. Pequena História Crítica. São Paulo: Annablume, 1997.

[18] MOREIRA, R. Pensar e ser em Geografia: ensaios de história, epistemologia e ontologia do espaço geográfico. São Paulo: Contexto, 2007.

[19] OLIVEIRA, J. R. Representações e práticas religiosas da Renovação Carismática Católica em Cachoeira Paulista: o exemplo da Canção Nova. Espaço e Cultura (UERJ), v. 1, p. 36-54, 2011.

[20] ROCHA, Genylton Odilon Rêgo da. O Colégio Pedro II e a institucionalização da geografia escolar no Brasil Império. Giramundo, Rio de Janeiro, v.1, n.1, p.15-34, jan./jun., 2014.

[21] ROSENDAHL, Zeny; CORRÊA Roberto Lobato (Org.). Espaço e Religião: Uma Abordagem Geográfica. 2a. ed. Rio de Janeiro: EdUERJ, 2002. 89p

[22] ROSENDAHL, Z:; CORRÊIA, Roberto Lobato. Introdução à Geografia Cultural. 6a. ed. Rio de Janeiro: Bertrand Brasil, 2014.v. 1. 224p.

[23] ROSENDAHL, Zeny. Hierópolis: o sagrado e o urbano. 2. ed. Rio de Janeiro: EdUERJ, 2009. v. 1.118p .

[24] ROSENDAHL, Zeny Primeiro a obrigação, depois a devoção. 1ed. Rio de Janeiro: EdUERJ, 2012. v. 1.

[25] SANTOS, Milton. A Natureza do Espaço: técnica e tempo, razão e emoção. São Paulo: Hucitec, 1996.

[26] SANTOS, Milton. Por uma Geografia Nova. São Paulo: Edusp, 2002.

[27] SAQUET, Marcos Aurélio (Org.); SPOSITO, Eliseu Savério (Org.). Territórios e territorialidades. Teorias, processos e conflitos. 1. ed. São Paulo: Expressão Popular, 2009. v. 1. 365p.

[28] SCOCUGLIA, J. B. C. ; FARIAS . A indissociabilidade entre patrimônio material e imaterial no estudo das culturas e identidade: a festa do Rosário e a cidade de Pombal. In: Jovanka Baracuhy C. Scocuglia. (Org.). Cidade, Cultura e Urbanidade. 1ed.João Pessoa: Editora Universitária da UFPB, 2012, v. 1, p. 379-410.

[29] SERPA, A. S. P. O Trabalho de Campo em Geografia: Uma Abordagem Teórico-Metodológica. In: Boletim Paulista de Geografia, v. 84, p. 7-24, 2006.

[30] SPOSITO, Eliseu Savério. Geografia e Filosofia. Contribuições para o ensino do pensamento geográfico. São Paulo: Ed. UNESP, 2004. 218 p

[31] SUERTUEGARAY, D. M. A. Pesquisa de Campo em Geografia. Revista GEOgraphia. Ano IV, no 7. Niterói, 2002.

[32] VENTURI, Luís Antônio. O papel da técnica no processo de produção científica. In: Boletim Paulista de Geografia, v. 84, p. 69-76, 2006. 


\section{Capítulo 6}

Identidade, Simbolismo e Pertencimento: 0 caso da Região Missioneira

\section{Luiz Felipe Sausen de Freitas \\ Iolanda Lopes de Oliveira \\ Vera Maria Favila Miorin}

Resumo: A Região Missioneira do Rio Grande do Sul tem se destacado nos últimos anos por direcionar suas ações fazendo alusão à história jesuítica e guarani que ocorreu no lugar a mais de trezentos anos. Símbolos do passado têm sido acionados no presente, fazendo com que os atuais habitantes vivam coletivamente a mesma história, gerando uma espécie de identidade muito marcante que se percebe localmente, podendo esta ser caracterizada como missioneira, pautada, sobretudo por sentimentos de pertença, os quais são induzidos por aqueles que detêm o poder e controlam as representações sociais.

Palavras-chave: Identidade; Simbolismo; Pertencimento. 


\section{INTRODUÇÃO}

Muito tem se falado no apego ao lugar e no pertencimento que se verificam no Rio Grande do Sul, onde se constatou que algumas regiões buscam enfaticamente a diferenciação, gerando identificações locais, advindas muitas vezes do poder simbólico, que ao introduzir marcas no território, induz suas populações a vivenciarem as mesmas histórias, gerando identidades coletivas com relação ao lugar. 0 caso da Região das Missões, situada no noroeste gaúcho é relevante nesse sentido, visto que a região foi palco de uma história diferenciada que uniu jesuíta e grupos nativos, principalmente os da tribo Guarani. A história deixou marcas na região, principalmente através dos remanescentes arquitetônicos do período histórico, onde se destacam as ruínas do Sítio Arqueológico de São Miguel Arcanjo, tombado pela UNESCO como Patrimônio Histórico e Cultural da Humanidade desde 1983.

A história gloriosa do passado tem sido constantemente evidenciada atualmente, fazendo com que a região se diferencie das áreas limítrofes, principalmente através do uso de símbolos que se remetem ao contexto histórico, induzindo a população local a reviver o período e de certo modo se sentir identificada com tal contexto, introduzindo relações de pertença. 0 apego ao lugar e as relações identitárias advindas do poder simbólico correspondem a alvos de estudos da geografia cultural, onde através da abordagem de alguns autores pretende-se explorar a questão com um direcionamento para a região missioneira do Rio Grande do Sul.

\section{DESENVOLVIMENTO}

O simbolismo verificado regionalmente não se restringe as ruínas das reduções, visto que, muitas marcas que fazem alusão ao período histórico, são cada vez mais evidenciadas localmente, fazendo com que os sujeitos se relacionem diretamente com esses símbolos, gerando sentimentos de pertença. 0 poder advindo do simbolismo normalmente ocorre devido à intencionalidade de unir grupos de diferentes origens, visando integra-los, gerando laços comunitários, instituindo localmente o que alguns autores classificam como "mito fundador". Silva (2014) ressalta que o mito fundador costumeiramente faz referência a um episódio crucial do passado, onde se enfatizam alguns acontecimentos, principalmente aqueles destacados por sua grandiosidade, pelo caráter épico ou heroico, gerando assim as bases formadoras de identidades, normalmente nacionais. 0 autor ainda lembra que pouco importa se os fatos contados são verdadeiros ou não, importando na verdade os resultados obtidos pelas narrativas que servem para identificar determinado grupo com determinada história vivida no lugar.

O geógrafo cultural Paul Claval (2007) também ressalta a importância do mito fundador na institucionalização do espaço, aferindo que os ritos estabelecidos por diferentes sociedades fazem alusão ao rito de fundação, permitindo o reestabelecimento das condições originais no momento em que as práticas cotidianas fazem esquece-las. De acordo com o autor, raízes antigas, históricas, míticas, ancestrais e étnicas acabam conferindo aos povos, o seu direito territorial, principalmente por o julgarem sagrado. 0 caso missioneiro se encaixa perfeitamente no contexto explorado por Silva (2014) e Claval (2007), visto que a experiência do passado teve como personagens; guaranis e jesuítas, os quais foram expulsos pelas tropas ibéricas, em consequência a região acabou sendo ocupada por portugueses e em período mais recente por imigrantes, principalmente alemães, italianos e poloneses. Percebe-se então que habitantes atuais da região, com exceção dos remanescentes Guaranis que ainda povoam a região, não possuem relação nenhuma com aqueles que foram parte importante da história, porém são cada vez mais incentivados a se sentirem missioneiros, por viveram no palco da grande história.

0 fato de as pessoas viverem no lugar vem a ser o elo comum que os une. Isso ganha relevância a partir de uma ressignificação do passado colonial, que fez com que a população atual, passasse a valorizar as mesmas histórias, lendas e personagens heroicos. Nas décadas de 1970 e 1980, a região se notabilizou por direcionar suas ações de modo a dar relevância ao passado regional, que até então era pouco explorado, dando importância ao seu passado colonial, atribuindo-lhe novo sentido e gerando uma espécie de imaginário social missioneiro, como enfatiza Pommer (2008) em seu trabalho acerca da identidade missioneira. Os povos que não tiveram relação com tal história foram induzidos a reviver o mesmo passado, que foi retomado e introduzido no que a autora caracteriza como "missioneirismo".

Neste caso, chama a atenção à presença de certo hibridismo com relação à identidade que se busca analisar. Silva (2014), afirma que o hibridismo tem sido costumeiramente analisado com relação ao processo de produção de identidades nacionais, raciais e étnicas, sendo que em uma perspectiva teórica cultural contemporânea, torna-se uma espécie de mistura entre diferentes nacionalidades, etnias e raças que acabam falseando as identidades fundamentadas por separação, divisão ou segregação. Estas 
identidades formadas em meio a certo hibridismo são, para o autor, novos tipos de identidades, as quais embora não possuindo caráter de uma identidade original, guardam traços da mesma, porém formando outra.

Para Claval (2007) muitas estratégias organizadas para situações multiculturais nem sempre objetivam a integração individual ou a proteção identitária, pois muitas vezes a mesma visa a construção de uma nova identidade a partir de tais mudanças. Mesmo diante da ressignificação ocorrida e do enaltecimento simbólico entorno das Missões, cabe destacar que os vínculos com o lugar ocorreram também por todo processo histórico, onde o grande grupo, através de suas vivências adquiriu relações com o espaço que vive.

0 pertencimento se verifica acima de tudo no discurso, sempre endereçado as Missões. Atuam localmente como símbolos representativos, a Cruz Missioneira, presente principalmente nos trevos de acesso aos municípios da região, além da imagem do Sítio Arqueológico de São Miguel Arcanjo, presente em propagandas turísticas, com o intuito de atrair visitantes. 0 personagem marcante é Sepé Tiaraju, morto em confronto com tropas ibéricas, o qual ficou famoso pela célebre frase: "Está terra tem dono". 0 que acontece localmente é de certo modo explicado por Claval (2007), o qual revela que a tomada de posse em certo espaço povoado vem a exprimir-se pela delimitação de fronteiras e pela consequente introdução de marcas que exprimem e orientam a uma identidade comum, com evidenciação a cruzes, monumentos e arquiteturas tipificadas, para evidenciar de certa forma a proclamação pertinente ao que se quer. Para o autor a tomada de posse se insere em uma lógica simbólica que acaba sendo assumida em caráter coletivo.

Silva (2014) destaca os sistemas de representação, que para o autor possuem grande importância quando se fala de identidade, principalmente aquelas pautadas pela diferença. Para o autor, tanto identidade quanto diferença são estreitamente dependentes da representação, pois, é por meio dela que ambas ganham sentido, de certo modo, passam a existir, pois representar significa na situação analisada, afirmar: "essa é a identidade" ou " a identidade é isso". Percebe-se também, no viés analisado, a força dos sistemas de poder, pois são eles que têm o poder de representar, ou seja, o poder pode definir e determinar o direcionamento identitário desejado. Em sua exposição, o autor também comenta que questionar a identidade é de certa maneira, questionar seus meios de representação.

Para Jodelet (2001) as representações são sociais e possuem grande relevância na vida cotidiana, pois as mesmas acabam guiando cada ser, nomeando e definindo um conjunto dos mais variados aspectos da realidade do indivíduo, de maneira que o mesmo possa interpreta-los e se necessário for, defende-los de acordo com as tomadas de posições. Claval (2007) contribui com a análise afirmando que os grupos humanos exercem papel importante na exploração espacial ao inserirem sistemas de representação que induzem ao pensar, logo a prática de batizar lugares muito vezes acaba reproduzindo o objeto de discurso, visto que a imposição de marcas simbólicas faz delas uma categoria social.

Jodelet (2001) ainda contribui afirmando que as representações sociais possuem em seu objeto uma relação de "simbolização", tomando seu lugar de interpretação e consequentemente atribuindo-lhe significações. Tais significações, por sua vez, resultam de uma atividade que torna a representação uma "construção" do sujeito. Esta atividade pode remeter a processos cognitivos, com o sujeito sendo considerado do ponto de vista epistêmico ou até mesmo a mecanismos intra-psíquicos (projeções fantasmáticas, investimentos pulsionais, identitários, motivações etc.), onde o sujeito é considerado do ponto de vista psicológico. 0 que chama atenção, é que o estudo das representações sociais tem o intuito de integrar em sua analise processual, o pertencimento e as participações sociais e culturais do sujeito.

Segundo Corrêa (2007) é por meio das formas simbólicas que a cidade expressa determinada cultura, realizando de acordo com os objetivos dominantes, o seu papel de transformação cultural. Para o autor, as formas simbólicas foram se alterando com o passar do tempo, estando as mesmas na atualidade, fortemente remetidas a bens e serviços com algum significado de ordem emocional ou intelectual, caracterizadas como instrumentos de comunicação. Muitos municípios missioneiros valorizam o simbólico em suas construções urbanas, São Miguel das Missões destaca-se neste sentido, com algumas construções comerciais que de certa forma fazem alusão ao período reducional. Para Corrêa (2007) quando se ressignifica a paisagem urbana, a mesma adquire valor simbólico, transformando-se em um tipo particular de mercadoria, manifestando assim, de um lado o papel de representar a realidade social e de outro, viabilizando a circulação do capital, se notabilizando pelo caráter eminentemente político.

Os monumentos, que evidenciam heróis, acontecimentos importantes ou símbolos históricos, são normalmente introduzidos num território público, sendo fontes de lembranças, de direcionamento coletivo de algo que já não existe mais, porém, de certa maneira alude à origem e à essência, conservando 
o modelo de identidade em sua versão mais autêntica. Saquet e Briskievicz (2009) ao estudarem a questão, ressaltam:

Os símbolos que compõe uma identidade não são construções totalmente eventuais; mantem sempre determinados vínculos com a realidade concreta. Os vários conflitos pela defesa de fronteira, por exemplo, demonstram que as referências espaciais permanecem relevantes para a definição ou fortalecimento de identidades. A própria memória (coletiva) de um grupo social precisa de uma referência territorial (SAQUET e BRISKIEVICZ, 2009, p.6).

Percebe-se diante dos estudos de Corrêa (2007) que a paisagem constitui parte de um conjunto compartilhado de ideias, memórias e sentimentos, que acabam unindo a população em torno de algo comum. $\mathrm{O}$ autor ainda ressalta que sentimentos e simbolismos impactam sobre o futuro, podendo assim relevar a dimensão identitária presente na paisagem urbana, oriunda de forte enfoque social e político. Com isso, de acordo com Lefebvre (2006) percebe-se que o espaço social se manifesta pela sua polivalência, possuindo uma "realidade" que é ao mesmo tempo forma e material. Com isso, o autor revela o espaço social como um produto que de certo modo se utiliza, se consome e é também meio de produção, de acordo com suas redes de trocas, fluxos de matéria-prima e energia que acabam recortando o espaço e que são por ele produzidos.

Os sistemas de representações são marcadamente verificados na Região Missioneira, com um simbolismo significativo, que faz com que a região se diferencie de áreas circundantes fazendo reverência ao passado histórico. A Cruz de Caravaca, popularmente conhecida como Cruz Missioneira é um símbolo histórico do período e está intensamente inserida no contexto regional atualmente. A famosa cruz missioneira é muito presente nas rodovias da região, especialmente nos trevos de acesso aos municípios locais, servindo atualmente como meio de identificar os municípios locais, como missioneiros. Muitos municípios também trazem consigo, a cruz missioneira em seus brasões municipais. Apesar de a cruz indicar uma conotação religiosa advinda da presença jesuítica na região, atualmente é usada como modo de representar uma ligação com a terra e com a história missioneira, sendo utilizada pela população para caracterizar sentimento de apego e pertença ao lugar. A figura 1 mostra a Cruz no trevo de acesso ao município de Entre-Ijuís.

Devido ao fato de a imagem do Sítio Arqueológico de São Miguel de Arcanjo ser intensamente explorada, principalmente a partir do frontispício da igreja, a mesma faz com que a região seja divulgada externamente. Logo, para o turista ou para pessoas que não vivem o contexto local, as Missões acabam sendo representadas por essa imagem, da qual os locais acabam fazendo uso também no sentido de informar, de localizar as pessoas sobre o lugar de origem. 0 que se verifica na relação da população com a Cruz Missioneira e a imagem proporciona pela Igreja de São Miguel, é de certo modo caracterizada por Lefrebvre (2006), que enfatiza que os corpos dos indivíduos, que agem como usuários, estão de certa maneira ligados as engrenagens espaciais, como que sendo análogos em termos filosóficos, como imagens, símbolos e signos.

O simbolismo entorno da Redução de São Miguel Arcanjo é significativo, sendo usado nas construções locais, principalmente em prédios comerciais, onde se percebe esse direcionamento. Algumas construções tentam lembrar a igreja da redução local, um exemplo marcante é um hotel que vem sendo construído próximo ao trevo de São Luiz Gonzaga por um célebre artista local. Pode se perceber nas figuras 2 a imagem da fachada da igreja de São Miguel Arcanjo, e na figura 3 o uso de uma referência do passado usada na construção do Hotel, uma espécie de réplica endereçada ao contexto missioneiro. 
Figura 1: Cruz Missioneira no trevo de acesso ao município de Entre-Ijuís, RS.

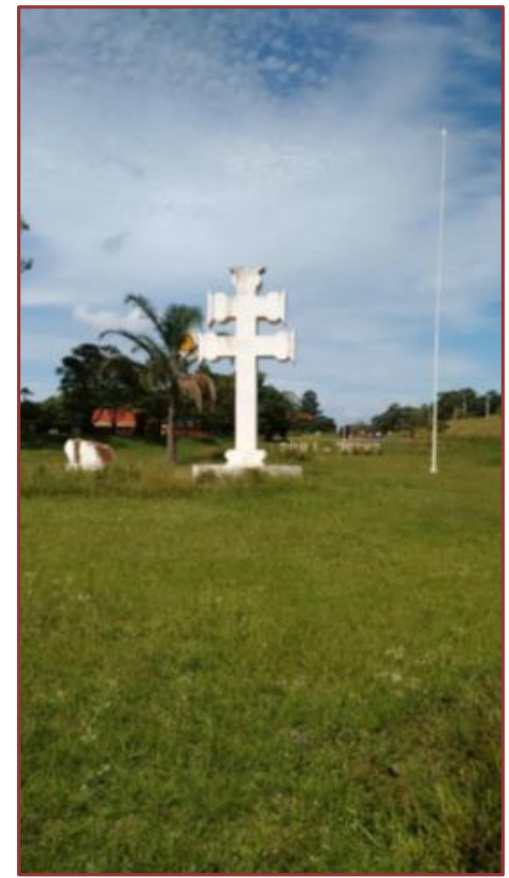

Foto: Autor

Figura 2: Sítio Arqueológico de São Miguel Arcanjo. Foto: Autor/ Figura 3: Hotel em Construção São Luiz Gonzaga, RS.
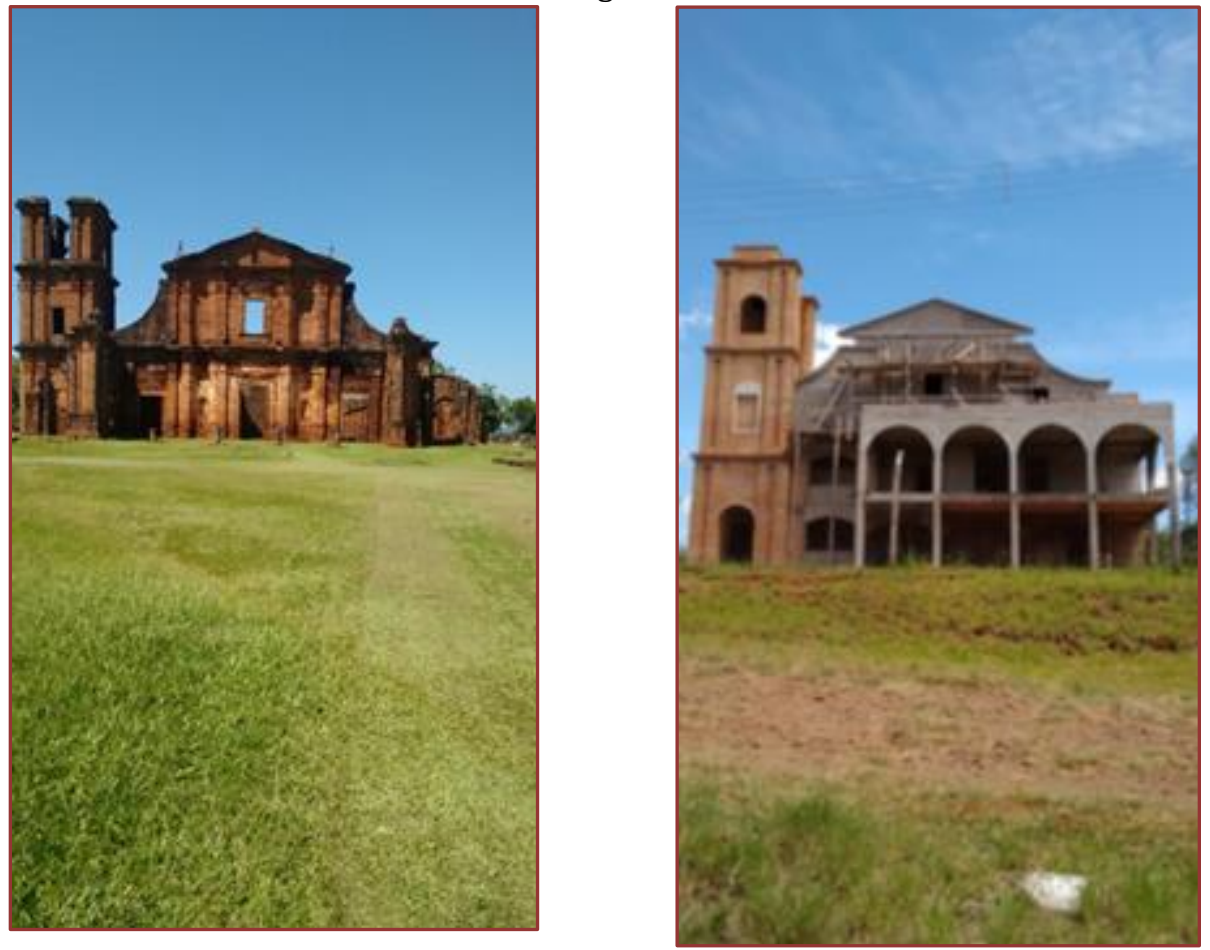

Foto: Autor

Percebe-se a partir dos estudos de Hall (2006) que o fenômeno identitário é dependente de diversas variáveis, que muitas vezes podem agir em conjunto. 0 discurso direciona a identidade para a direção que anteriormente talvez tenha sido provocada, pelo fechamento e a marcação de fronteiras em alguns casos, principalmente no contexto dos laços nacionalistas, mas também pela marcação simbólica, que também enfatiza a diferença, produzindo formas de pertença e de ligação afetiva para com o lugar. 


\section{REFERÊNCIAS}

[1] CLAVAL, P. A Geografia Cultural. Florianópolis. 3a edição. Editora da UFSC, 2007. 453p.

[2] CORRÊA, R.L. A Geografia Cultural e o Urbano. In: Introdução a Geografia Cultural. Orgs: Corrêa, R.L. Rosendahl, Z. Bertrand Brasil. Rio de Janeiro. 2007. p-167-186.

[3] HALL, S. A identidade cultural na Pós-Modernidade. Rio de Janeiro. DP\&A. 2006. 104p.

[4] JODELET, D. Representações Sociais: um domínio em expansão. In: D. Jodelet (Ed.) Les Représentations Sociales. Paris: 1989, p-31-61. Tradução: Tarso Bonilha Mazzotti. UFRJ. Faculdade de Educação. 2001.

[5] LEFEbVRE, H. A produção do Espaço. Trad. Doralice Barros de Oliveira, Sérgio Martins. Primeira Versão. 2006.

[6] POMMER, R.M.G. Missioneirismo: A Produção de uma Identidade Regional. Tese de Doutorado. 2008.325 f. Tese (Doutorado em História)-Universidade do Vale do Rio dos Sinos. São Leopoldo. 2008.

[7] SAQUET, M.A.; BRISKIEVICZ, M. Territorialidade e Identidade: Um patrimônio no desenvolvimento territorial. Caderno Prudentino de Geografia, $n^{\circ} 31$, vol. 1. Presidente Prudente. 2009. p. 3-16.

[8] SILVA, T.T. A produção social da identidade e da diferença. In Silva, Tomaz Tadeu (2014). Identidade e diferença: a perspectiva dos estudos culturais. p.73-102. 


\section{Capítulo 7}

\section{Geograficidade no Bumba Meu Boi do Maranhão à luz da memória de brincantes}

\section{Luciléa Ferreira Lopes Gonçalves \\ Salete Kozel Teixeira \\ Allison Bezerra Oliveira}

Resumo: 0 presente texto apresenta as geograficidades de brincantes do Bumba meu boi do Maranhão, registradas na coletânea intitulada Memória de Velhos: depoimentos. 0 objetivo é analisar as geograficidades de brincantes contidas nessas memórias registradas e que refletem o universo simbólico, as crenças, os conflitos, ideia de mundo, lugares e paisagem sonora. As análises têm como aporte teórico a fenomenologia de Eric Dardel e da Geografia Cultural. Parte-se do entendimento que essa orientação teórica não separa o sujeito do objeto, o ser do mundo, compreendendo o mundo como lugar, lugar do real. 0 texto está referenciado pelo conceito de geograficidade e de lugar. Estes conceitos geográficos assemelha-se a interpretações fenomenológicas de "mundo". Tuan (2013) proporciona o entendimento de que "o lugar é construído a partir da experiência e dos sentidos, envolvendo sentimentos e entendimento, num processo de envolvimento geográfico do corpo amalgamado com a cultura [...]". Assim, apresenta-se a festa do Boi no Maranhão como uma experiência com o lugar, pois estudos apontam que o Maranhão é a base do desenvolvimento dessa festividade. 


\section{CONSIDERAÇÕES INICIAIS}

A capacidade que a Geografia atual possui de explicar a relação do homem no espaço, ou no mundo vem da caminhada que ela trilhou, para organizar no contexto teórico-metodológico, seu categorial espacial ou suas essências. Nesse contexto, situamos as categorias paisagem e lugar, que possuem significativo espaço de discussões na Geografia Cultural, com estudos voltados para a percepção dos indivíduos, para a subjetividade dos grupos sociais, buscando compreender o significado que os homens atribuem ao espaço.

A geografia das festas insere-se nas temáticas da Geografia Cultural e tem análises e discussões sobre a dimensão sócio territorial de festas e festividades. A festa do Boi, objeto de discussão neste texto, no que se refere à escala territorial, vai além do recorte municipal, visto que as apresentações da festa do Boi acontecem em vários espaços. Nesse caso, organizam territórios imbricados em outros territórios. Os sentidos da festa, também são diferentes para quem organiza, para quem dança e para quem assiste.

0 presente texto apresenta as geograficidades de brincantes do Bumba meu boi do Maranhão, registradas na coletânea intitulada Memória de Velhos: depoimentos. O objetivo é analisar as geograficidades de brincantes contidas nessas memórias registradas e que refletem o universo simbólico, as crenças, os conflitos, ideia de mundo, lugares e paisagem sonora. As análises têm como aporte teórico a fenomenologia de Eric Dardel e da Geografia Cultural. Parte-se do entendimento que essa orientação teórica não separa o sujeito do objeto, o ser do mundo, compreendendo o mundo como lugar, lugar do real. 0 texto está referenciado pelo conceito de geograficidade e de lugar. Estes conceitos geográficos assemelha-se a interpretações fenomenológicas de "mundo". Tuan (2013) proporciona o entendimento de que "o lugar é construído a partir da experiência e dos sentidos, envolvendo sentimentos e entendimento, num processo de envolvimento geográfico do corpo amalgamado com a cultura [...]". Assim, apresenta-se a festa do Boi no Maranhão como uma experiência com o lugar, pois estudos apontam que o Maranhão é a base do desenvolvimento dessa festividade.

A experiência geográfica com o lugar, por meio da festa do Bumba meu boi no Maranhão é observada pela relação profunda com as coisas do lugar, especializadas nos diferentes símbolos como toadas, coreografias, batismo, cazumbás, dança e instrumentos em um compartilhamento comum no sentido de fazer a festa.

Nesse sentido, e tomando como referência a geografia fenomenológica de Eric Dardel, que para Holzer (2011), une a perfeição ciência e filosofia, é que coloca-se o Bumba meu boi como fenômeno a ser interpretado pela geografia cultural-humanista. Considera-se para isso que, no Bumba meu boi do Maranhão, os símbolos que compõem as suas paisagens estão presentes: na religiosidade com seu caráter sincrético. Essa festa imbrica símbolos e ritos de diferentes crenças; na estética; na sonoridade; nas indumentárias e nos instrumentos que evidenciam, principalmente, a influência das culturas africana, indígena além da europeia. Compreende-se, assim, que esse "Complexo Cultural" é resultante de relações com o seu entorno material e imaterial.

\section{GEOGRAFICIDADE, UMA ABORDAGEM GEOGRÁFICA}

O termo geograficidade chaga na geografia nos anos de 1970, por meio das discussões de Edward Relph, $(1970,1973)$ e Yi-Fu-Tuan $(1974,1977)$, influenciados pela obra de obra de Eric Dardel, "O Homem e a terra: natureza da realidade geográfica", cuja edição ocorreu em 1952, na França. A obra de Eric Dardel (1952) repercutiu na geografia dos anos de 1970, no coletivo dos geógrafos humanistas que buscavam alternativas para a predominância do paradigma positivista e neopositivista, até então, e permitiu a reconstrução teórico-metodológica na geografia, com adoção da fenomenologia. De acordo com Holzer (2011 "[...] possivelmente o que atraiu estes jovens geógrafos norte-americanos na leitura do livro de Dardel foi o encadeamento entre geografia e fenomenologia que ele oferece." (HOLZER, 2011, p. 144).

Também, Kozel; Souza (2009, p. 124), situando as contribuições da "geosofia" de Wright (1974); a valorização da experiência vivida de Lowenthal (1961) atribuem a essa diversidade de olhares "maior liberdade e significados às pesquisas que atualmente se expandem por vários países".

Para Dardel (2011), geograficidade se refere à cumplicidade obri;2011gatória entre a Terra e o homem em que se realiza a existência humana. "Amor ao solo natal ou busca por novos ambientes, uma relação concreta liga o homem à Terra, uma geograficidade do homem como modo de sua existência e de seu destino". (DARDEL, 2011, p.1-2. Grifo do autor).

0 que define a geograficidade? O Homem que é existência, presença na Terra, que é suporte de sua existência e elemento de seu desenvolvimento. É o Ser-no-mundo. A situação, direção e a distância mundo 
e lugar onde ele se move um conjunto de "[...] relações e de trocas; direções e distâncias que fixam de algum modo o lugar de sua existência." (DARDEL, 2011, p. 14. Grifo do autor).

Se a historicidade é destino; Geograficidade é existência, é a inserção do elemento terrestre na vida do homem. Assim, a compreensão de geograficidade está na relação entre as pessoas e os lugares, lugares compreendidos como o encontro com os sujeitos, espaço experenciado, vivido. Nesta perspectiva, envolve os "lugares configurados do mundo", do "ser-no-mundo" pelo qual suas referencialidades e significatividade por meio de sua cotidianidade, se mostram.

A Geografia fenomenológica de Dardel (2011) é bastante presente na discussão do conceito de lugar. Vários são os registros em sua obra da noção de lugar como relações temporais e espaciais do ser no mundo, de sua geograficidades. Dardel (2011, p. 40 e 42) expõe: "Igualmente imaginário é o fato de que, nas relações indicadas por habitar, construir, cultivar, circular, a Terra é experimentada como base"

Holzer (2010, p.3) expõe:

Dardel, em “O Homem e a Terra” não dedica um capítulo ou item especifico para discutir a questão do lugar. Ao contrário o conceito permeia o texto como fundamento para a construção de todas as relações temporais e espaciais do ser-no-mundo.

Influências de Lévinas, igualmente são registradas quando escreve sobre lugar:

Em nossa relação primordial com o mundo, tal como se manifesta nesse gesto banal, ao nos abandonarmos assim 'às virtudes protetoras do lugar', firmamos nosso pacto secreto com a Terra, expressamos, por meio de nossa própria conduta, que nossa subjetividade de sujeito se encolha sobre a terra firme, se assente, ou melhor, 'repouse'. É desse 'lugar', base de nossa existência, que, despertando, tomamos consciência do mundo e saímos ao seu encontro, audaciosos ou circunspetos, para trabalhá-lo. Há, no lugar de onde a consciência se eleva para ficar de pé, frente aos seres e aos acontecimentos, qualquer coisa de mais primitivo que o 'lar', o país natal, o ponto de ligação, isto é, para os homens e os povos, o lugar onde eles dormem, a casa, a cabana, a tenda, a aldeia. (DARDEL, 2011, p.40-41).

Holzer (2011, p. 151), ao discutir sobre a distinção entre espaço geométrico e espaço geográfico elaborado por Dardel (2011), considera a preocupação do teórico, em colocar em oposição esses espaços. Esta oposição exigiria uma delimitação bastante precisa do espaço geográfico, que é objetivado em oposição ao espaço geométrico, desprovido de qualquer concretude existencialista. Segundo o autor:

A geometria opera sobre um espaço abstrato, vazio de todo o conteúdo disponível, disponível para todas as combinações. 0 espaço geográfico tem um horizonte, um modelado, cor, densidade. Ele é sólido, líquido ou aéreo, largo ou estreito: ele limita e ele resiste. (DARDEL, 2011, p.2).

Ainda sobre essa discussão, situa-se a afirmação de Dardel (2011) de que a geografia autoriza uma fenomenologia do espaço, o espaço concreto da geografia libera o homem do espaço, do espaço infinito do geômetra ou do astrônomo e "Desse modo, quando nos referimos à geografia enquanto ciência essencial, não seria a espacialidade o nosso objeto de estudo, mas a geograficidades". (HOLZER ,2011, p. 151)

A Geografia de Eric Dardel (2011) é um chamamento a interpretar a atividade humana não somente pela materialidade. Utilizando o significado etimológico da geografia 'descrição' da Terra, considera ser a geografia um "texto a decifrar". Sobre esse entendimento, Dardel (2011, p.2) enfatiza:

0 conhecimento geográfico tem por objeto esclarecer estes signos, isso que a Terra revela ao homem sobre sua condição humana e seu destino. Não se trata, inicialmente, de um atlas aberto diante de seus olhos, é um apelo que vem do solo, da onda, da floresta, uma oportunidade ou uma recusa, um poder, uma presença. 
Dardel (2011) ressalta que, geografia moderna, de origem renascentista, quando o homem se volta para o mundo exterior medindo-o, analisando-o, procurando compreendê-lo geograficamente, se opõe à geografia vivida em ato, referente à ligação do homem com sua terra natal. Nas conclusões, o autor deixa bem claro sua inquietação com a forma em que, na época de escrever o livro, ocorria o debate se realizava na Geografia. Assim, escreve:

É difícil imaginar em nossa época outra relação do homem com a Terra para além do conhecimento objetivo proposto por uma geografia científica. Esta vontade de promover uma ordem espacial e visual do mundo responde à tendência geral do pensamento ocidental nos tempos modernos. Visualização do mundo como imagem universal, como representação, que o homem tem presente diante de si para melhor dominá-la (DARDEL, 2011, p. 90).

Dessa forma, criticou o fazer geográfico da época. Os geógrafos erram, então, ao esquecer a função primordial da geografia, a de ser instância entre o conhecimento e a existência nesse contexto, expressa:

[...] descartando-se da ciência ela se perderia na confusão e na loquacidade. Entregando-se sem reservas à ciência ela se exporia ao que Jaspers chama de 'uma nova visão mítica', esquecendo-se de que uma atitude científica objetiva visa a uma compreensão total do mundo que não pode deixar de ser também moral, estética, espiritual. (DARDEL, 2011, p. 97).

Nessa perspectiva, a festa do Bumba meu boi, ao ser analisada pelo aporte geográfico-humanista, possibilita análises tanto das grandes estruturas, como do lugar, espaço geográfico onde se dão atividades ligadas à sobrevivência do homem. Assim sendo, a partir das experiências vividas nos lugares, o Bumba meu boi do Maranhão com seus ritos e ritmos oportunizam a compreensão de elementos próprios dessa festa.

\section{A FESTA DO BUMBA MEU BOI NO MARANHÃO}

O Bumba meu boi do Maranhão ou Bumba boi ou brincadeira de Boi ou simplesmente, Boi, como é conhecido no Maranhão é um Complexo Cultural ${ }^{4}$ conforme o (INSTITUTO DO PATRIMÔNIO HISTÓRICO E ARTÍSTICO NACIONAL 2011a), da cultura popular brasileira e, em 2019 foi aprovado pela Organização da Nações Unidas para a Educação, a Ciência e a Cultura (UNESCO) para integrar a lista internacional de Patrimônio Cultural e Internacional da Humanidade. De acordo com esse documento, essa brincadeira, considerada celebração, tem diversos elementos centrais e estruturantes no qual se destacam: o Boi, a festa, os rituais, a devoção aos santos - Antônio, São João, São Pedro e São Marçal-, a música, a dança, o teatro, o artesanato, as personagens, os instrumentos, os diversificados estilos de brincar o Boi e o caráter lúdico.

As literaturas sobre o Bumba meu boi maranhense situam que, provavelmente, sua origem é anterior ao século XIX. No Dossiê organizado pelo (INSTITUTO DO PATRIMÔNIO HISTÓRICO E ARTÍSTICO NACIONAL 2011a), para registro da festa do Boi do Maranhão, as informações estão sustentadas por folcloristas, etnólogos e antropólogos como Celso de Magalhães, Silvio Romero, Nina Rodrigues, Mário de Andrade, Renato Almeida, Câmara Cascudo, Arthur Ramos, Edison Carneiro e Amadeu Amaral. Nesses estudiosos, algumas proposições encontradas sobre o folguedo associam a origem em versões como:

- Tradição popular portuguesa trazida para o Brasil pelo Nordeste, com adaptação do teatro catequético dos jesuítas;

Celso de Magalhães, Silvio Romero, Mário de Andrade.

- Origem relacionada nos antigos cultos pagãos do Boi Ápis, bezerro sagrado cultuado no a ntigo Egito;

Nina Rodrigues, Arthur Ramos, Edison Carneiro.

- Fusão de elementos portugueses e nativos;

Renato de Almeida e Câmara Cascudo.

${ }^{4}$ O Bumba meu boi do Maranhão foi registrado no processo no 014500077272/2008-61, pelo Instituto do Patrimônio Histórico e Artístico Nacional- IPHAN, no livro de Registro de Celebrações como Complexo Cultural do Bumba meu boi do Maranhão em 30 de agosto de 2011. 
As versões da tradição popular portuguesa trazida para o Brasil pelo Nordeste, com adaptação do teatro catequético dos jesuítas, bem como a da fusão de elementos portugueses e nativos são relacionadas ao ciclo do gado, no Nordeste brasileiro, irradiando-se, posteriormente, para as outras regiões do Brasil.

No que se refere a registro jornalístico sobre a festa do Boi, alguns do século XIX são referenciados por pesquisadores. No Maranhão, em 1829 em jornais e ocorrências policiais datadas da década de 20 à década de 90, no jornal "Farol Maranhense"; Em Santa Catarina, em 1871; em Pernambuco, em 1840 no jornal "O Carapuceiro"; nos dos periódicos, "A Voz Paraense" e "O Velho Brado do Amazonas”, no Pará, em 1850; e dos livros "Reise durch Nord-Brasilien im jahre 1859", do alemão Robert Avé-Lallemant, e "Águas passadas”, de José Boiteaux, com relatos de bumba meu boi em Manaus, em 1859.

Esses documentos, de certa maneira, são usados para justificar o período de origem da festa do Boi, sua proibição e também, o fim das proibições. Também, crônicas e romances são usadas como referência de origem.

A festa do Boi apresenta-se como lazer, diversão, religiosidade, misticismo, drama e festa. Segundo França; Reis, (2007, p.43), "o ' "bumba”' vem do som da zabumba, mas, para outros, trata-se de uma interjeição, que daria à expressão vários sentidos, como ' "Vamos, meu boi”! ', ' "Aguenta meu boi”! ' ou “ "Bate meu boi"! "'.

A festa do Boi é considerada de longo calendário com várias etapas de um ciclo que inicia com reuniões estratégicas para assegurar recursos, a apresentação do homenageado e a escolha das toadas. A culminância da festa acontece no mês de junho, mas estende-se até setembro ou outubro.

\section{OS CICLOS OU ETAPAS OU RITUAIS OU CELEBRAÇÕES DO BOI}

Ensaios, de caráter preparatório, iniciam no sábado de aleluia e encerram no dia de Santo Antônio, 13 de junho, ou até ao sábado mais próximo deste, quando acontece o ensaio redondo (último ensaio), fechando essa fase. Nesta primeira etapa, são apresentadas novas toadas que são norteadoras dos bordados do couro $^{5}$ do Boi.

Batismo, realizado no dia 23 de junho para receber a bênção de São João (protetor da festividade). Considera-se que, a partir desse dia, o Boi está pronto para a temporada de apresentações. Esta etapa possui uma estreita relação com o catolicismo, caso seja observado o ritual do batismo dessa religião. Ferreira; Silva (2008, p.5), sobre o batismo do Boi no Maranhão, descrevem:

0 batismo do boi, guardadas as devidas relativizações, segue os rituais do batizado católico, tem sempre um padre que dirige a cerimônia e os padrinhos que são escolhidos entre os membros da comunidade ou pessoas influentes da sociedade local. A imagem de São João fica no plano mais alto, como a derramar suas bênçãos a todos os presentes, especialmente ao boi, que é colocado de frente para o altar, coberto com um pano branco sobre dois cavaletes de madeira enfeitados com flores e folhagens.

Apresentações públicas, concentradas, principalmente, no mês de junho com datas importantes como o dia 23, dia do batismo; o dia 29 data em que todos os grupos se apresentam na Praça de São Pedro (onde fica a capela do Santo); dia 30, homenagem a São Marçal pelo sotaque de matraca. A homenagem é no bairro do João Paulo, em São Luís, marcando o fim das apresentações do período junino nos arraiais. As apresentações são verdadeiras maratonas em "arraias" ou largos e nos mais variados locais que contratam o Boi, e compreendem: o guarnicê, quando o amo do Boi chama o grupo para começar a apresentação; o lá vai, aviso de que a brincadeira está se dirigindo ao local da apresentação; a licença, que é a permissão para que o grupo se apresente ao público; a saudação, quando são cantadas toadas de louvação ao dono da casa e ao Boi; o urrou, a celebração da alegria de todos pelo restabelecimento do Boi depois de ter sido sacrificado e a despedida, quando a apresentação é encerrada.

Morte do Boi, marcando o final da temporada anual das festas, esta etapa pode acontecer em qualquer mês do segundo semestre. No Boi da Maioba, ocorre na última semana do mês de julho.

A nomeação do Bumba meu boi no Maranhão como Patrimônio Cultural e Internacional da Humanidade decorre de estudos realizados pelo Iphan em anos anteriores ao registro. Nesses estudos, sotaques, religiões além de diferentes instrumentos, danças e objetos foram catalogados. Dessa forma, é digno de

\footnotetext{
${ }^{5}$ Capa de veludo bordada que é colocada sobre a armação do Boi
} 
ressaltar a coerência para a referida nomeação, pois, conforme (INSTITUTO DO PATRIMÔNIO HISTÓRICO E ARTÍSTICO NACIONAL 2011, p. 100):

Os grupos de Bumba meu boi constituem um vasto e complexo conjunto de características em suas expressões artísticas, estéticas e simbólicas. 0 folguedo se desenvolve sob inúmeras variantes, apresentando diversos ritmos, danças, instrumentos, músicas, personagens, dramas e indumentárias. Há uma variedade de estilos para celebrar a brincadeira, sendo essa uma particularidade do Bumba-boi maranhense. Surgem por diferentes motivos e em diversos lugares e, consequentemente, com atributos peculiares a cada região de ocorrência, mas com qualidades que os individualizam e dão vivacidade ao universo da festa.

Essa capacidade de se (re) significar, no entanto, não resguardou o Boi de uma classificação. As literaturas mais antigas e as mais recentes (como o Dossiê de registro) fazem uma classificação considerada como útil para direcionamento de estudos e pesquisas, bem como para a execução de ações dos poderes públicos. Assim, os Bois estão classificados, tanto pelos grupos como pelas entidades (associações, mídia, governo municipal e estadual) que organizam as apresentações, por "estilos" ou "sotaques" de:

Zabumba ou de Guimarães desenvolveu-se na região do Litoral Ocidental maranhense nos municípios de Guimarães e Cururupu, mais especificamente nas comunidades negras. Atualmente, em São Luís, existem muitos grupos de Bois da Zabumba. 0 som característico desse sotaque (lento e socado) é produzido por grandes tambores ou tantãs (as zabumbas), maracás e uma espécie de tamborim tocado com a mão. Possui uma composição conhecida como rajado que é formado por homens que fecham a brincadeira em forma de círculo e, assim, chamam a atenção pelos grandes e pesados chapéus de fitas coloridas. Seus brincantes usam roupas com golas e saiotes de veludo preto bordado com miçangas e canutilhos. A figura do boi é menor do que as do sotaque de orquestra e matraca, sendo seu "couro" todo bordado com miçangas e canutilhos. É o mais antigo dos sotaques.

Costa de mão ou de Cururupu localizado no município de Cururupu, no Litoral Ocidental do Maranhão produz som com caixa, maracá e pandeiro, que é pendurado com auxílio de fio no pescoço, para facilitar a batida de costa de mão. Os homens usam bermudões de veludo bordados, com meias até a altura do joelho e chapéus afunilados e enfeitados com fitas coloridas e grinaldas de flores. As mulheres, com exceção das índias, usam saias bordadas.

Matraca ou da Ilha por ser predominante na Ilha de São Luís. Tem um som estridente produzido pelas batidas uma contra a outra das matracas (feitas de madeira de diferentes tamanhos) e pandeirões (arcos de madeira coberto com pele de animais ou industrializado). Atrai grande público que se tornam brincantes durante as apresentações por tocarem suas matracas, denominando-se também matraqueiros ${ }^{6}$. São destaques, nesse grupo, os caboclos de pena que usam grandes coroas confeccionadas com penas de ema; pai Francisco usa um facão feito de madeira e a burrinha feita de buriti, coberta com veludo bordado e uma grande barra de pano estampado com um buraco ao centro, a fim de possibilitar a entrada de um brincante. Outro personagem do boi de Matraca é o tapuia que junto com os caboclos de pena formam o cordão de rajados e dançam um forte bailado. Os mais famosos na Ilha são o boi da Maioba, de Maracanã e o de São José de Ribamar.

Orquestra originou-se na região do rio Munim, onde se encontram as comunidades do Boi de Morros e de Axixá, porém um grande número de brincadeiras desse sotaque existe na Ilha de São Luís e região circunvizinha. Com um som alegre produzido por banda de instrumento de sopro e corda (piston, saxofone, clarinete, banjo e bumbo), suas indumentárias têm uma grande variedade de cores. Dessa forma, os brincantes que formam o cordão de pessoas usam peitinho (espécie de babador) e saiote bordados, além de chapéu com fitas e maracás. Com danças coreografadas e bailado alegre, realizadas por pessoas vestidas como índias e índios, juntamente com os demais brincantes, tal sotaque possui um forte apelo popular nos festejos juninos.

Baixada ou de Pindaré predominante na Baixada Maranhense, tem como marcas principais os instrumentos percussivos como tambor-onça, caixas, pandeiros, maracás e pequenas matracas. Seus personagens são os rajados, os cazumbas, as índias, o amo e os vaqueiros. Peitorais e saiotes bordados enfeitam as indumentárias dos vaqueiros que usam calça e camisa de cetim de manga longa. Os rajados usam chapéu alargado na aba frontal dobrada para cima, bordada e adornada com penas de ema. Longas

${ }^{6}$ Brincante do Boi da Ilha, que toca matraca. 
fitas coloridas são fixadas ao chapéu, pendendo para trás. Os cazumbas, também chamados cazumbás, utilizam máscaras em formato animalesco e túnicas longas bordadas ou pintadas.

\section{GEOGRAFICIDADE NO BUMBA MEU BOI DO MARANHÃO À LUZ DA MEMÓRIA DE BRINCANTES.}

O uso dos registros de memória como técnica de pesquisa tem sido usado em estudos na geografia cultural. Holzer (2000, p.111), expondo pesquisas realizadas em 1998, considera que "qualquer trabalho que se refira à espacialidade humana deve referir-se à memória". Afirma que "Uma aproximação entre memória, história e espacialidade pode ser feita a partir da geografia humanista [...]".

Lowenthal (1985, p.105), debatendo sobre a Geografia, considera:

Como Geografia, entretanto, o universo mais amplo do discurso se centraliza sobre o conhecimento e ideias a propósito do homem e meio ambiente; qualquer pessoa que examine o mundo ao redor de si é, de algum modo, um geógrafo.

Nesse sentido, o autor em destaque escreve: “Cada ser vivendo em um lugar constrói conhecimentos que lhe são próprios e representam o resultado de suas percepções". Lowenthal $(1985$, p.119, 138) também compreende que: "O meio ambiente privado inclui muito mais paisagens e conceitos variados do que o mundo compartilhado, forças e lugares imaginários como também aspectos da realidade, com os quais só o indivíduo está familiarizado". Ainda para o referido autor, "O conhecimento pessoal, assim como o geográfico, é uma forma de ocupação sequencial. Assim como a paisagem ou um ser vivo, cada mundo pessoal teve um curso no tempo, uma história própria".

As paisagens relatadas são essências e conhecimentos de uma realidade geográfica, no caso, espaços como São Luís, São Vicente de Férrer ${ }^{7}$, Madre Deus ${ }^{8}$, Viana ${ }^{9}$ e a Maioba, que se tornaram lugares da festa do Boi para os brincantes, isto é, lugares com lugaridade, conforme discutida por Relph (2014):

Lugaridade - (qualidade própria do lugar) se funda nos seus aspectos constitutivos (como a autenticidade, o encontro, o sentido de lugar, o espírito do lugar entre outros), sendo melhor entendida enquanto uma gradação, tendo níveis em contextos diferentes. Lugares autênticos seriam aqueles com forte lugaridade, enquanto os não-lugares e os placelessness seriam aqueles que possuem ausência de lugaridade, ou seja, lugares-sem-lugaridade. [...] (RELPH, 2014, p. 25).

A exposição sobre o Bumba meu boi remete os brincantes para além dos espaços imediatos no qual estão envolvidos com o Boi; no caso, Madre Deus, Maioba e São Luís. É válido pensar, nesse caso, que, ao relatarem seus próprios lugares, construídos com vivências e experiências na infância e na vida adulta, os brincantes oferecem a festividade do Bumba meu boi, como um lugar de estudo sobre geograficidade maranhense.

Ciente da importância de sua experiência com a festa do Boi, José de Jesus Figueiredo, (apud MARANHÃO, 1999, p.119). em depoimento, afirma:

Sinto-me gratificado pela oportunidade que estou tendo de fazer, antes de morrer, uma matéria gravada e escrita sobre a minha trajetória, no que diz respeito ao Bumba-meu-boi, para outras pessoas conhecerem essa história e meu filho conhecer uma matéria feita com meu nome, com meu sentimento, em tudo quanto ocorreu comigo.

Em discussões sobre a harmonia dos mundos particulares com a realidade, Lowenthal $(1985$, p. 120) assevera "[...] o que as pessoas percebem sempre pertence ao mundo "real" compartilhado; até as paisagens dos sonhos advêm de cenas verdadeiras recentemente vistas ou relembradas da memória, consciente ou não [...]". Também, Lowenthal (1985, p.123) expõe: "A experiência do mundo mais simples e direta é composta de percepção, memória, lógica e fé".

\footnotetext{
7 Município do Maranhão, localizado na Baixada.

8 Bairro de São Luís

${ }^{9}$ Município do Maranhão, localizado na Baixada.
} 
Torres; Kozel (2012) consideram a importância da comunicação estabelecida entre as pessoas que compõem a cultura do grupo, para uma abordagem que considere as experiências individuais e o universo simbólico.

Os sotaques de Matraca ou da Ilha, Costa de Mão ou de Cururupu, Zabumba ou de Guimarães, Baixada e Orquestra, pelas leituras das memórias, procedem do movimento real da vida dos brincantes, como migrar, criar, pagar promessa a São João, ter dificuldades, desavenças e outros. Eventos que são às vezes responsáveis no aparecimento de mais um Boi ${ }^{10}$.

As leituras das memórias revelam os brincantes em uma situação, colocada por Dardel (2011) como definidora da geograficidade:

No plano da geografia a noção de situação extravasa para os domínios mais variados da experiência do mundo. A 'situação' de um homem supõe um 'espaço' onde ele 'se move'; um conjunto de relações e de trocas; direções e distâncias que fixam de algum modo o lugar de sua existência. 'Perder a localização', é se ver desprovido de seu 'lugar', rebaixado de sua posição 'eminente', de suas 'relações', se encontrar, sem direções, reduzido à impotência e à imobilidade [...] (DARDEL, 2011, p.14).

No seu habitar, cultivar, viver, o brincante do Boi esteve ligado à geografia dos lugares por onde andou. Nesse aspecto, muitas paisagens foram observadas nas memórias. Porém, não é uma simples descrição das mesmas e sim paisagens, conforme apresenta Dardel (2011, p. 30), "Muito mais que uma justaposição de detalhes pitorescos, a paisagem é um conjunto, uma convergência, um momento vivido, uma ligação interna, uma 'impressão', que une todos os elementos".

Nessa perspectiva, apresenta-se como centro era o espaço elitizado que procurava, a todo custo, banir ou, pelo menos, controlar o Bumba meu boi e o subúrbio, locais de atuação do Bumba. Essa realidade é encontrada nos depoimentos de brincantes como o que segue:

As apresentações iam até o Posto Fiscal e voltavam, não podiam passar. Eu tenho a impressão de que incomodavam o povo antigamente. [...] Certa vez escutei na Rádio Educadora: falavam mal desta brincadeira, que não tinha êxito porque era feita por pessoas pobres, pretas, feias e analfabetas; que os tambores de crioula eram para serem dançados por misses. [...] No São João, no Centro da cidade, tocavam fogos, foguetes, mas não havia boi, porque não podia passar. (JOSÉ COSTA DE JESUS apud MARANHÃO, 1999, p.168).

A periferia coincidia com o bairro do Anil que se tornou centro dos folguedos, onde, tradicionalmente, o Bumba meu boi se apresentava no mês de junho; também coincidia como o bairro do João Paulo que era o limite entre o centro e a periferia da cidade. Assim, em sua experiência com o lugar, José de Jesus Figueiredo revela sua geograficidade com a paisagem sonora do Boi de Viana, descrevendo o som que identifica:

Em 1956, quando morava com minha tia, na Rua do Coqueiro, abaixo do ginásio Costa Rodrigues, no bairro do Curupira, numa determinada noite escutei um batuque de boi... Ih! Rapaz! Quase fico doido em casa. Era o boi de Viana, do finado José Apolônio, [...]. Era justamente o mesmo sotaque da minha terra. [...] Tive vontade de correr atrás, mas, chegando recentemente a São Luís, não tinha autorização da minha tia para sair. Fiquei só curtindo e não sei o que aconteceu. Numa outra oportunidade, eles foram brincar lá perto e não tive como resistir. Eles amanheceram e corri para ver [...]. [...] Quando ouço o batuque do meu sotaque, fico trêmulo. [...] O Batuque sereno, pegando firme, a rapaziada cantando uma toada, todo mundo abrindo a boca certinho, a toada entoando, ô! Aquilo é lindo, lindo demais. Sinceramente, é aí que é a minha diversão... [...]. (JOSÉ DE JESUS FIGUEIREDO apud MARANHÃO, 1999, p.101,114).

E o som se traduz em sentimento, lembrança, ligação com o mundo inicial. Conforme Torres (2014, p. 50), "Os sons possuem relação direta com a memória. Ao ouvir determinados sons, ou sequência, uma pessoa pode rememorar momentos vividos no passado".

10 É o Boi aqui pensado como mais uma brincadeira ou grupo que pertence a alguém ou a uma associação com brincantes, cantador, Pai Francisco, vaqueiros, Catirina, Índias. 
Essa experiência com o lugar revelada pelos sons é resultante do sentimento de pertencimento e identificação com o lugar manifestada pelos brincantes. Assim, João Francisco assegura seu pertencimento: "Nasci na Maioba, de onde nunca sair". Igualmente, José Raimundo Ferreira afirma: "Nascido e criado na Maioba". Também, José Costa de Jesus, "Eu era de família pobre, aqui na Maioba". Ou quando relata: "Fiz um boi e dei à Maioba: brincou seis anos. Compus uma toada referente aos 100 anos: quem entendeu, agradeceu;". (João Francisco do Espírito Santo; José Raimundo Ferreira; José Costa de Jesus apud MARANHÃO, 1999, p. 147, 149, p. 161,163,164).

Também, pelas memórias, os brincantes esclarecem como o aparecimento de um grupo de Boi está, intimamente, ligado à família, à preservação da cultura pela família conforme depoimento em destaque:

Mãe Rita, está com a idade de 106 anos, conta que teve dois bois: no Durico era de Simplício. Depois vieram o boi do Piri, perto da Pindoba, e da Trizidela, do avô Raimundinho, o do Estribão, em que meu avô brincou; depois veio o do senhor Pedro Botijão, que era da minha família do meu tataravô, por aí... A brincadeira era assim, suponhamos: aqui, nesse local onde moro, fazia-se. Para outro ano, uma pessoa pegava a cabeça do boi e fazia lá na frente; continuou assim. De uns tempos para cá, mudou. (JOSÉ COSTA DE JESUS, apud MARANHÃO, 1999, P.163).

Igualmente, o papel das mulheres é reconhecido conforme depoimento de Marciano Vieira Passos (apud MARANHÃO, 1997, p. 78,79):

A família toda saia. É como as mulheres daqui da Madre Deus dantes saia, acompanhava o boi. Hoje em dia não. Naquele tempo elas saiam desde de noite, entrava de manhã junto comigo e pronto. Assim que era. Cada uma acompanhava seu marido, cada uma acompanhava seus filhos, como minha mãe. Essa minha madrinha me acompanhava, minhas irmãs tudo me acompanhava.

Ao relatarem seus próprios lugares, construídos com vivências e experiências na infância e na vida adulta, os brincantes oferecem a festividade do Bumba meu boi, como um espaço de estudo sobre geograficidade maranhense.

Embora, na atualidade, prevaleçam os registros externos como fotografar e filmar, a memória oral dos brincantes revela-se como documento de um período em que as experiências com o lugar ficaram registradas. 0 universo simbólico, as crenças, os conflitos, ideia de mundo, lugares e paisagem sonora estão registradas nos depoimentos. Parte-se do entendimento que a geografia cultural não separa o sujeito do objeto, o ser do mundo, compreendendo o mundo como lugar, lugar do real. Os depoimentos sobre a festa do Bumba-meu-boi revelam um conhecimento sobre essa festa constituída na relação ser no mundo, revelando a geograficidade dos brincantes.

\section{CONSIDERAÇÕES FINAIS}

Os registros bibliográficos sobre a festa do Bumba meu boi revelam um conhecimento constituído na relação ser no mundo. Apresentam geograficidades de brincantes contidas em experiências que refletem o universo simbólico, as crenças, os conflitos, ideia de mundo, lugares e paisagem sonora.

Nesse sentido, por terem sido personagens dos fatos narrados, os depoentes constituem-se em provas dos mesmos, denotando relevante contribuição para a história do Bumba meu boi. Além disso, essas memórias são narrativas de afetos, desafetos, vida familiar inseridos em uma conjuntura política e econômica de um determinado tempo histórico que, pelos brincantes, ganham significatividade e particularidade. Percebese nos depoimentos, como foram constituídas as geograficidades do Bumba meu boi na ilha de São Luis, formada tanto com as resistências às forças coercitivas como pela incorporação nessa cidade, da ideia de centro e periferia ou subúrbios, pensadas não somente como divisões geográficas, mas transcendendo para dimensões socioeconômicas, políticas e culturais. Também nas paisagens relatadas encontram-se experiências de sons, cheiros e movimentos. São essências e conhecimentos de suas realidades geográficas. 


\section{REFERÊNCIAS}

[1] DARDEL, Eric. O Homem e a terra: natureza da realidade geográfica (Primeira edição 1952); Tradução Werther Holzer. São Paulo: Perspectiva, 2011.

[2] FERREIRA, Carla George; SILVA, Carlos Benedito Rodrigues da. Festejar com fé: o bumba-meu-boi maranhense uma cumplicidade com São João. V Simpósio Internacional do Centro de Estudos do Caribe no Brasil. Disponível em: www.revistabrasileiradocaribe.org/Carla FerreiraCarlosSilva. Acesso em 01.09.2009.

[3] FRANÇA, Jeovah Silva; REIS, José Ribamar Sousa dos. A Nova Geração de Cantadores de Bumba-meu-boi da Ilha. São Luís: Valeumandoelegal Produções e Eventos, 2007

[4] HOLZER, Werther. Memórias de Viajantes: Paisagens e Lugares de um novo mundo. GEOgrafia (Rio de Janeiro. Online), ano II, no3, p.111-122, 2000.

A influência de Eric Dardel na Construção da Geografia humanista Norte Americana. In: Anais... XVI En contro Nacional dos Geógrafos (ENG): crise, práxis e autonomia: espaços de resistência e de esperanças - Espaço de Socialização de Coletivos. Porto Alegre: AGB, 2010.

. A Geografia fenomenológica de Eric Dardel. In: DARDEL, Eric. 0 homem e a terra: natureza da realidade geográfica. São Paulo: Perspectiva, 2011. p. 141-153.

[5] INSTITUTO DO PATRIMÔNIO HISTÓRICO E ARTÍSTICO NACIONAL.Complexo Cultural do Bumba-meu-boi do Maranhão: dossiê do registro como Patrimônio Cultural do Brasil. São Luís: Iphan/MA, 2011.

[6] KOZEL, Salete; Souza, Lucileyde Feitosa. Parintins, que espaço é esse? Representação espacial sob a ótica do morador e do visitante. In: KOZEL, Salete; SILVA, Josué da Costa; FILIZOLA, Roberto; GIL FILHO, Sylvio Fausto. Expedição Amazônica: Desvendamento espaço e representações dos festejos em comunidades amazônicas. A festa do boi-bumbá: um ato de fé. Curitiba. SK editora: 2009, p. 117, 143.

[7] LOWENTHAL, David. Geografia, Experiência e Imaginação: Em Direção a uma Epistemologia Geográfica. Geografia Humanística. In: CHRISTOFOLETTI, Antônio. Perspectivas da Geografia. 2ed. São Paulo: Difel, 1985. p. 103,141 .

[8] MARANHÃo. Fundação cultural. Centro de Cultura Popular Domingos Vieira Filho. Memórias de velhos _ Depoimentos: uma contribuição à memória oral da cultura popular maranhense. São Luís: Lithograf, 1997. Vol. III.

[9] MARANHÃo. Fundação cultural. Centro de Cultura Popular Domingos Vieira Filho. Memórias de velhos _ Depoimentos: uma contribuição à memória oral da cultura popular maranhense. São Luís: Lithograf, 1999. Vol. V.

[10] RELPH, Edward. Reflexões Sobre a Emergência, Aspectos e Essência de Lugar. In: MORANDOLA, JR.; HOLZER, Werther; OLIVEIRA, Lívia de. Qual o espaço do lugar? São Paulo: Perspectiva, 2014. p.17-32.

[11] TORRES, M. A.; KOZEL, Salete. A paisagem sonora da Ilha dos Valadares: percepção e memória na construção do espaço. In: BARTHE-DELOYZE, Francine;

[12] SERPA, Angelo (Orgs.). Visões do Brasil: estudos culturais em geografia. Salvador: EDUFBA; Edições L'Harmattan, 2012.

[13] TORRES, M. Os Sons que unem: A paisagem sonora e a identidade religiosa. Tese (Doutorado) Programa de Pós-Graduação em Geografia, Curitiba, 2014, 231p.

[14] TUAN, Yi-FU. Espaço e lugar: a perspectiva da experiência. Eduel: Londrina, 2013. Tradução: Lívia de Oliveira. 


\section{Capítulo 8}

Da Centralidade Simbólica a Centralidade Socioterritorial de Macapá na Amazônia Setentrional Amapaense

Alex de Lima Santos

João Paulo de Almeida Amorim

Júlia Diniz de Oliveira

Élida Thalita Silva de Carvalho

Diogo Bernardino Santos de Medeiros

Resumo: 0 objetivo deste texto é analisar como se constitui a centralidade urbana da cidade de Macapá, no estado do Amapá no contexto urbano e regional do recorte regional denominado Amazônia Setentrional Amapaense - ASA. Neste tema, busca-se através de revisão bibliográfica analisar a formação histórico-geográfica da centralidade de Macapá, sua passagem para uma centralidade política provocada pela transformação em Território Federal, sua posterior passagem de território federal para ente federativo e, a criação da Área de Livre Comércio de Macapá e Santana. Busca-se através desse recorte analítico compreender seu papel atual na rede urbana regional, em que a capital amapaense surge portadora de uma centralidade socioterritorial.

Palavras-chave: Centralidade, Macapá, Amazônia Setentrional Amapaense. 


\section{INTRODUÇÃO}

0 processo de urbanização no espaço amazônico passou por transformações, principalmente a partir da segunda metade do século $\mathrm{XX}$, vários foram os fatores - a abertura das rodovias, os grandes projetos minerais, a expansão da pecuária, a industrialização pontual da Zona Franca de Manaus e a intensificação produtiva da agricultura da soja, dentre outros. Lefebvre (1999) reflete sobre a urbanização como um fenômeno onde a sociedade, principalmente a partir da industrialização caminha para o que o autor chamou de sociedade urbana.

0 processo de urbanização acentuou-se consideravelmente no decorrer do século passado e trouxe consigo rupturas e permanências que incidem nos processos de produção e estruturação do espaço urbano (OLIVEIRA JÚNIOR, 2008).

Apesar dessa transformação e tentativa de homogeneidade na sociedade contemporânea, o urbano, enquanto fenômeno, se desperta de formas diferentes, principalmente na escala nacional, em especial na região amazônica. Uma maneira de se pensar essa diferenciação do espaço urbano é através do olhar da centralidade na Amazônia. Trindade Jr. (2018) destaca que, na Amazônia ocorrem diversos tipos de centralidades resultantes das primeiras atividades econômicas na região (borracha, castanha, garimpo, agricultura) e mais recentemente aos grandes empreendimentos, agronegócio e em especial a centralidade política.

O fenômeno da centralidade para Lefebvre (1999) é um fenômeno dialético, pois ao mesmo tempo em que cria, destrói para formar a centralidade, ela exige o conteúdo para sua realização neste processo. No entanto, existem outras visões de centralidade que permitam uma melhor compreensão da realidade na Amazônia.

A criação dos territórios federais na região, a partir da estratégia governamental de resguarda das fronteiras impulsionou o movimento de centralização administrativa em diversas cidades, dentre elas Macapá (Figura 1). A atual capital foi institucionalizada em 1943 (anteriormente, o município de Amapá possuía esse posto), e, no mesmo ano, foi criado o Território Federal do Amapá, juntamente com outros cinco territórios federais, localizados em faixa de fronteira justificando-se o ato na defesa nacional: Amapá, Rio Branco (atual Roraima), Guaporé (atual Rondônia), Ponta Porã e Iguaçu (esses dois últimos retornaram aos seus estados de origem pela Constituição de 1946) (PORTO, 2014).

Trindade Jr. (2016) afirma que, no caso amazônico, a centralidade política é responsável pela projeção de algumas cidades em nível regional. Macapá se apresenta como uma Capital Regional C (REGIC, 2008; 2018), todavia, essa classificação, grosso modo, não dá conta da realidade sub-regional na Amazônia Setentrional Amapaense - ASA (SANTOS 2012).

Macapá aparece como centro e importante "nó" na rede urbana e regional, não só como polo dentro do estado amapaense, mas também no que tange às ilhas do golfão marajoara por projetar sua influência nessa porção mais setentrional da Amazônia (AMORIM, 2016).

A regionalização proposta por Santos (2012), mostra Macapá pertencente à Sub-região de Macapá - SRM, e se configura como seu centro econômico e político (SANTOS e AMORIM, 2015). 0 seu trabalho inicia uma discussão que mostra a importância desta sub-região junto às ilhas do golfão marajoara, denominada subregião da Foz do Amazonas ${ }^{11}$.

Bitoun (2018) afirma que algumas cidades no Brasil, principalmente na região central e ocidental, são os únicos recursos "urbanos" para populações, por conta das distâncias que as separam de outras cidades. Nesse caso, pode-se pensar a sub-região da Foz do Amazonas como parte desse contexto, ao utilizar os recursos de Macapá ao verificar sua relativa proximidade, se comparada com a metrópole mais próxima, Belém/PA.

Tais cidades tornam-se importantes, independente de seus tamanhos populacionais e do papel que desempenham, pois, a falta de alternativas para as populações circunvizinhas acaba por servir de ponto de busca de serviços de baixa e média complexidade, principalmente serviços de saúde pública. Essa forma de pensar as relações entre os municípios na ASA ajuda a compreender as centralidades em contextos regionais particulares, dentre eles o papel de Macapá:

11 A sub-região das Ilhas da Foz do Amazonas pode ser considerada como a sub-região de ocupação mais antiga da ASA. É formada pelas ilhas do Arquipélago do Marajó que pertencem aos municípios de Chaves, Afuá e Gurupá do estado do Pará, pelas das ilhas do Arquipélago de Bailique que pertencem ao município de Macapá e, da face ribeirinha da área Metropolitana de Macapá (SANTOS, 2012, p. 221). 


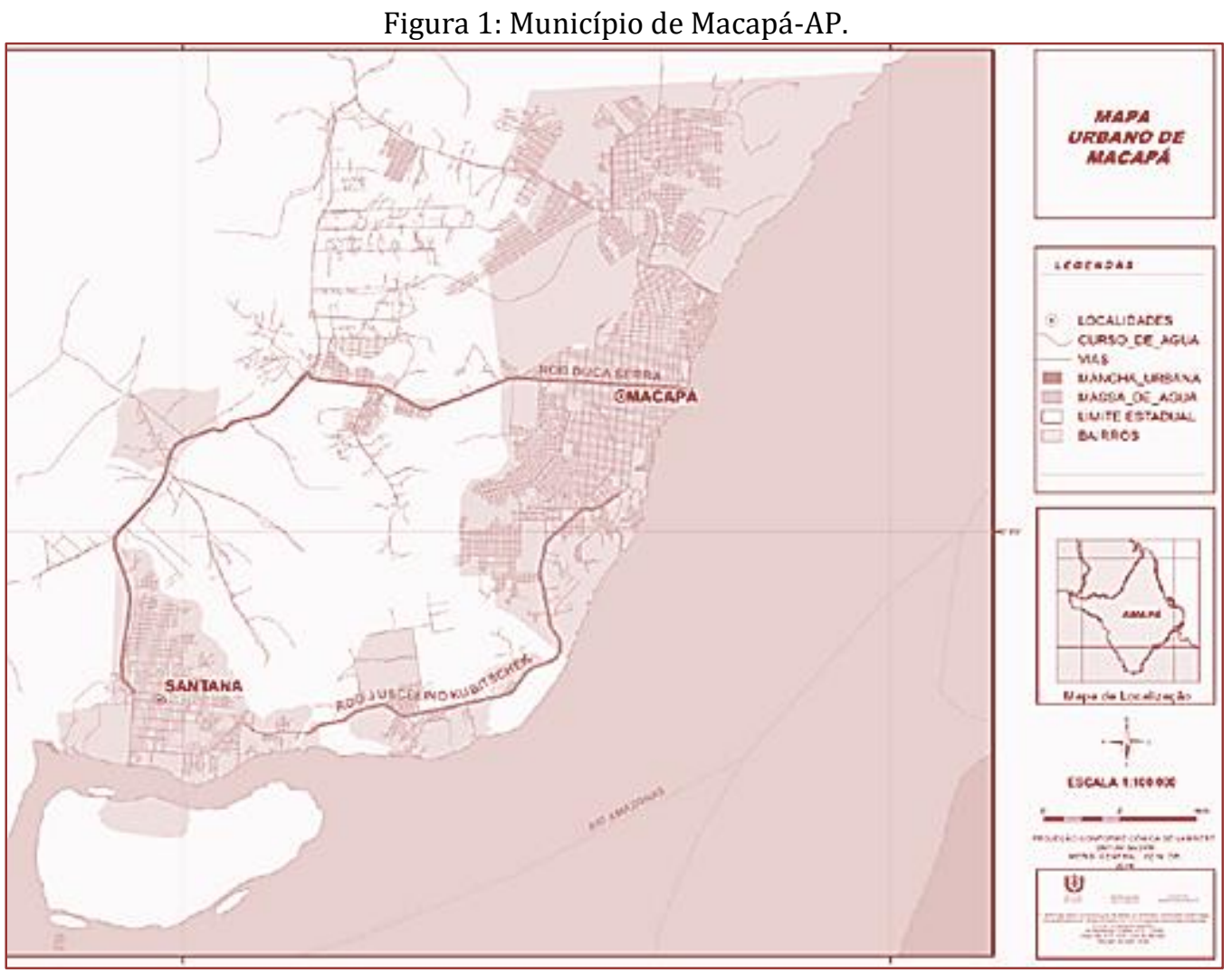

Fonte: Governo do Estado do Amapá.

O fato do município de Macapá ter se voltado para um padrão espacial estrada terra firme - subsolo, não implicou no abandono do padrão rio - várzea floresta, pelo contrário, ambos se articulam e são imprescindíveis para o desenvolvimento da ASA como um todo [...]. É na orla fluvial da Região Metropolitana de Macapá, que estão os principais pontos de conexões para o escoamento da produção agroextrativista ribeirinha e do embarque de produtos industrializados que irão abastecer as cidades, vilas e lugarejos das ilhas da Foz do rio Amazonas (SANTOS, 2012, p. 223).

Macapá se constitui historicamente na utilização desses dois padrões de ocupação, sem perder de vista sua conexão com o rio e suas populações. Sua face ribeirinha denota a importância da economia regional e o elo que desenha uma passagem para uma centralidade que Trindade Jr. (2015) chama de centralidade socioterritorial, onde se permite analisar a região para além de uma centralidade política e econômica, revelando a fragmentação e urbanização difusa no território amazônico.

Nesse sentido, se faz mister avançar na discussão e apreensão de como se dá a relação de Macapá com o seu entorno, tanto no aspecto intra como interestadual, pois essa dinâmica explica, em grande parte, o crescimento populacional e espacial da capital amapaense ao longo das últimas décadas. 0 estudo da centralidade das capitais regionais, como Macapá ajuda a compreender como as dinâmicas sub-regionais se desenvolvem entre os espaços funcionais na região e como servem para induzir novas transformações no espaço urbano da Amazônia. Além disso, a configuração urbana e regional amazônica apresenta características, de certa forma, distintas do típico urbanismo industrial apresentado nas regiões do sudeste e sul brasileiro, o que denota um aspecto ímpar da urbanização, onde os rios e a floresta possuem um papel importante em sua condição urbana.

\section{CENTRALIDADE: APORTES TEÓRICOS}

Diversos autores vêm discutindo a questão da centralidade, no campo das ciências humanas, no entanto, não é o objetivo deste texto fazer uma discussão teórica fastidiosa do que vem ser a centralidade, mas sim de abordar as concepções que possam facilitar a compreensão de centralidade proposta por Trindade Jr. (2015). 
Nesse contexto, uma das concepções interessantes sobre o conceito é a de Lefebvre (1999, p. 113):

A centralidade advém desde o primeiro recolhimento e da primeira recolecção de objetos dispersos na natureza, desde o primeiro ajuntamento de amontoado de frutos. Ela anunciava sua realização virtual. Desde o princípio, reunir, amontoar, recolher é algo de essencial na prática social; é um aspecto racional da produção que não coincide com a atividade produtiva, mas dela não se dissocia (LEFEBVRE, 1999, p.113).

Ao remontar a ideia de centralidade ao período de coleta, característico das sociedades primitivas, o autor afirma que essa prática seria a origem virtual da prática social de centralidade, continua sua observação a partir do reconhecimento dos signos urbanos na afirmação de que a "centralidade se através da reunião, que são os signos do urbano". São as coisas que permitem a reunião (a rua e a superfície da rua, pedra, asfalto, calçado, etc.), todavia, no decurso de sua realização, a concentração sempre enfraquece e se rompe.

A corrente de pensamento da Geografia teorético-quantitativa afirma que a centralidade tende a ocorrer onde há maior variedade na oferta de bens e serviços, em uma estrutura urbana delimitada a partir de hierarquias intra e interurbana. Logo, a centralidade surge como função das áreas que ocupam o comando da hierarquia urbana ${ }^{12}$. Essa hierarquia é entendida a partir da teoria central da localização de Christaller.

Essas dinâmicas produzem novas formas de apropriação do espaço urbano e, também, novas formas de centralidade, a partir de transformações econômicas, que são portadoras de preferências de localização para a produção e consumos de bens e serviços na estrutura interna das cidades, ainda afirma que, nessa conjuntura urbana existem níveis de especificidade que devem ser estudados a partir de cada formação socioespacial e cada conjuntura econômica. Para Spósito (2013, p. 73):

A centralidade não é, propriamente, concreta; não pode ser vista numa imagem de satélite; é difícil de ser representada cartograficamente, por meio de delimitação de um ser da cidade; não aparece desenhada no cadastro municipal ou no plano diretor das cidades; não se pode percorrê-la ou mesmo vê-la, embora possa ser sentida, percebida, representada socialmente, componha nossa memória urbana e seja parte de nosso imaginário social sobre a vida urbana (SPOSITO, 2013, p.73).

A composição implícita simbólica presente na centralidade se encontra nos elementos urbanos que fazem parte da origem da cidade, dos objetos técnicos que possuem certo valor cultural para a cidade. Por exemplo, a Fortaleza de São José de Macapá possui esse valor simbólico por fazer parte da paisagem urbana da capital, ao longo do tempo, desde sua fundação como Vila, até hoje. Antes como resguarde da fronteira, hoje como memória viva de outrora.

Trindade Jr (2011) afirma que a centralidade se dá na Amazônia através da capacidade de circulação (sistema de fluxos) de serviços e mercadorias presentes no centro urbano, não sendo simplesmente centros locais, mas núcleos urbanos com capacidade de polarizar e influenciar um número significativo de cidades menores e articular relações de toda ordem.

Uma noção de centralidade que se aproxima de Lefebvre (1999), quando pensada como o amontoar e reunir na prática social, onde e rio é elemento que reúne os aspectos tanto materiais, quanto simbólicos e é nele que se inscreve a rede de articulação das ilhas amazônicas com suas primeiras cidades.

Trindade Jr. (2015) chama de 'centralidade socioterritorial', na qual se permite analisar a região para além de uma centralidade política e econômica, revelando a fragmentação e urbanização difusa no território amazônico.

O surgimento desta nova centralidade, imbuída de elementos culturais, simbólicos e do imaginário amazônico surge em uma relação dialética entre os elementos capitalistas de apropriação da propriedade privada, bens de produção e da força de trabalho e o modo de vida ribeirinho, com a coexistência de elementos do urbano, cada vez mais presentes, na produção (social, política, cultural) e do consumo desses grupos sociais.

12 Corrêa (2012) tece críticas acerca dessa visão de Centralidade, por considerar o estudo sobre centros de mercado desprovido de conhecimento crítico e espacial, ao homogeneizar classes sociais distintas em suas análises "escamoteando a realidade". 


\section{CENTRALIDADE SIMBÓLICA DE MACAPÁ}

A cidade de Macapá, no estado do Amapá, fundada em 1751 como Vila de São José de Macapá, no período pombalino e, posteriormente como cidade em 1856 apresentou-se, desde sua fundação, ligada a dois projetos da coroa portuguesa: o primeiro insere a vila de Macapá com seu desenvolvimento baseada nas fortificações, como base de defesa territorial e geopolítica; o segundo projeto voltado para exploração econômica, visa à produção agrícola e povoamento da região (SANTOS, 2012).

Os primeiros núcleos e povoamentos sob o controle da Coroa portuguesa não eram difusos, mas estavam localizados ao longo dos rios, intencionalmente em locais ardilosos, que serviam de entrepostos à coleta, ao armazenamento e à distribuição dos produtos originados da floresta e servia de base aos espaços de produção agrícola do entorno das vilas recém-criadas (TRINDADE JR., 2015). Destarte, as vias fluviais (rios, igarapés e furos), funcionavam como redes de circulação de pessoas, mercadorias e informações inicialmente devido à exploração das "drogas do sertão" e, posteriormente, a outros fatores, tais como a agricultura comercial e a exploração da borracha.

Macapá surge como um dos espaços estratégicos de resguarda da desembocadura do rio Amazonas, chamada de "Cabo Norte", sua centralidade estratégica e simbólica reside aos objetivos de sua fundação, que, para defender a região de possíveis ameaças estrangeiras junto aos domínios dos portugueses, construiu a Fortaleza de São José de Macapá ${ }^{13}$ e também como celeiro agrícola com a prática da rizicultura (MARIN, 1995).

Foi principalmente em Macapá e nas áreas vizinhas que o projeto rizícola apareceu de forma mais acabada e intensa durante trinta anos. Nesse período, a Amazônia sofreu o desenvolvimento de sua rede urbana sob a égide da Companhia Geral do Grão-Pará e Maranhão, coordenada pelo Marquês de Pombal que, teve como ideia embrionária, fomentar a passagem da acumulação de capital comercial em capital industrial em Portugal. As primeiras famílias de colonos se mantinham por meio de relações sociais coercitivas, para se estabelecer o cultivo agrícola (DIAS, 1970; QUEIROZ, 1999).

Durante algumas décadas, o povoamento da região se deu de forma instável, devido a endemias, insalubridade, proliferação de insetos e a precariedade dos núcleos e a baixa lucratividade da atividade agrícola, devido às expectativas criadas pelo regime de mercado que impôs excedentes cada vez maiores ao produtor, no entanto, a possibilidade de produzir excedente e vender se via de frente com os problemas do elevado preço das mercadorias e do sistema de encargos imposto pelo Estado (dízimos), que reduziram significativamente a lucratividade do empreendimento familiar (REIS, 1949; MARIN, 2005).

As relações com o mercado de Belém ficaram mais importantes. Com a saída da Companhia Geral do GrãoPará e Maranhão, todavia, para o contexto amazônico, Corrêa (1987) afirma que com o fim daquela Companhia, a Amazônia sofreu com a estagnação econômica e um lento processo de crescimento urbano.

A partir da segunda metade do século XIX, o povoamento da região ia crescendo, como demonstra Reis (1949), no qual grupos de populações, interessados na exploração de riquezas minerais, criação de gado e exploração de recursos naturais começam a ocupar a região entre o rio Oiapoque e o rio Araguarí.

Algumas décadas depois, o espaço da agricultura, aparentemente mais estável, com pequenas plantações de algodão na ilha Pará, o lado da Vila de Mazagão e a produção de farinha de mandioca para o consumo interno mostravam uma recuperação da região. A representação de fracasso e decadência da primeira colônia de Macapá, no século XIX, levou à realocação em cena de objetivos e interesses militares de ocupação da costa setentrional, em virtude de novos confrontos na região de fronteira, no início do século seguinte, por exemplo, com as repercussões do Movimento da Cabanagem, na região (MARIN, 1999).

Na primeira metade do século XX, as terras do atual estado do Amapá, que pertenciam ao estado do Pará ganham um novo desenho político e administrativo. Em 1943 foi criado o Território Federal do Amapá14 TFA, cuja capital fora a cidade de Amapá, onde se encontrava a base aérea construída pelos norteamericanos durante a $2^{\underline{a}}$ guerra mundial, e que possuía melhores condições de infraestrutura à época. Contudo, em 1944, esta capital foi transferida para Macapá, por determinação do então Governador Janarí

\footnotetext{
${ }^{13}$ A grande fortaleza só foi inaugurada em 19 de março de 1782, 18 anos depois de iniciados os trabalhos. Erguida a imponente fortaleza, a vila de Macapá começou a desenvolver-se, sempre gozando das vantagens inerentes à sua qualidade de centro militar, até os dias que precederam à proclamação da Independência do Brasil. Macapá cresceu à sombra desta fortaleza, testemunho do esforço luso-brasileiro na conquista, colonização e manutenção da Amazônia e representa a mais vigorosa afirmação do domínio português no Território do Amapá. Teve papel relevante no laudo arbitral de Berna, em 1ํo de dezembro de 1900 (PORTO, 2014).

${ }^{14}$ Sobre a origem do Território Federal do Amapá, vide: Reis (1949) e Porto (2003).
} 
Nunes, e assim permanece até hoje. Esta transferência representou uma nova organização do espaço amapaense, como também uma nova organização de sua política territorial, pois determinou novos usos para a então recém-capital do Território, seja como receptor dos investimentos públicos de maior vulto; seja como receptor de investimentos privados pelo Grupo CAEMI (Companhia Auxiliar de Empresas de Mineração), pelo seu maior representante, ICOMI (Indústria e Comércio de Minérios Sociedade Anônima); seja pela sua conexão com o exterior pelo seu sistema portuário e aéreo; seja pela geração de uma nova elite política: os servidores públicos.

A partir deste movimento, a evolução populacional de Macapá, segundo dado do Instituto Brasileiro de Geografia e Estatística era, em 1950, de 20.594 habitantes, passa de 86.087 pessoas, em 1970, um crescimento de 418\%, ao longo de, somente duas décadas. A maioria, dessa população se lança na área urbana de Macapá, fato que ratificou a importância do desvencilhamento da região da administração paraense, pois provocou o crescimento e desenvolvimento do espaço urbano de Macapá.

Segundo Amaral (2010) o vetor de crescimento urbano da capital, que até 1964, apresenta o seu núcleo confundindo-se com seu centro comercial e de serviços, a partir da criação da Rodovia Juscelino Kubitscheck, Rodovia Duque de Caxias e BR - 156 ocorreram o crescimento em direção ao norte, oeste e sul da capital. Com relação às rodovias, estas apresentam a função de conexão regional, pois possuem atividades comerciais e de serviços voltados para o mercado regional.

Outro elemento importante deve ser considerado, trata-se do fato de uma significativa infraestrutura conurbada à Macapá, com considerável relevância regional (restante do Amapá e até mesmo ilhas do Golfão Marajoara) e até mesmo internacional, está situada na cidade de Santana, criada a partir do desmembramento territorial de Macapá em 1987 (Quadro 1).

Dentre esta infraestrutura, destaca-se o Porto de Santana onde se exportava o manganês extraído em Serra do Navio desde o período de criação da ICOMI S/A (1957), até o ano de 1997, quando ocorreu o encerramento de suas atividades no estado do Amapá. A Estrada de Ferro que liga o espaço de extração do minério ao porto, o distrito industrial de Macapá, que atualmente fica em Santana, os portos locais, como o "Porto do Grego", responsável por articular Macapá e Santana com várias cidades da Amazônia, principalmente com a Metrópole Regional Belém.

Quadro 1 - Eventos que marcaram a centralidade de Macapá.

\begin{tabular}{|c|c|}
\hline $\begin{array}{l}\text { CONTEXTO DA REDE } \\
\text { URBANA DO AMAPÁ }\end{array}$ & PROCESSO HISTÓRICO DE AFIRMAÇÃO DA CENTRALIDADE \\
\hline 1758 & Macapá é elevada à condição de vila \\
\hline 1856 & Macapá é elevada à categoria de cidade \\
\hline Fim do século XIX & Macapá cumpre o papel de entreposto durante o período da borracha \\
\hline $1943-44$ & $\begin{array}{l}\text { Criação do Território Federal do Amapá; Macapá é transformada na capital do Ex-Território } \\
\text { Federal do Amapá, com isso a Cidade de Macapá passa a concentrar os principais } \\
\text { investimentos públicos e privados do Estado. }\end{array}$ \\
\hline $1953-57$ & $\begin{array}{l}\text { Instalação e início das atividades da ICOMI S/A em Serra do Navio; criação da Central de } \\
\text { Eletricidade do Amapá - CEA }\end{array}$ \\
\hline 1979 & Construção da BR-156 \\
\hline $1985-87$ & $\begin{array}{l}\text { Plano de Desenvolvimento Integrado do Amapá; Criação de novos municípios no Amapá, } \\
\text { com destaque para a criação do município de Santana por desmembramento de Macapá }\end{array}$ \\
\hline 1988 & Estadualização \\
\hline 1991 & Criação da Área de Livre Comércio de Macapá e Santana - ALCMS \\
\hline 1996 & $\begin{array}{l}\text { Assinatura do Acordo Quadro Brasil-França } \\
\text { Expansão do Porto de Santana }\end{array}$ \\
\hline 2003 & $\begin{array}{l}\text { Expansão asfáltica da BR-156 até Calçoene; } \\
\text { Criação da Região Metropolitana de Macapá - RMM }\end{array}$ \\
\hline 2018 & Oficialização da Região Metropolitana de Macapá \\
\hline
\end{tabular}

Fonte: Adaptado de Santos (2016).

Neste sentido, Santos (2016) afirma à importância de se analisar de forma conjunta as cidades de Macapá e Santana, como indutoras do crescimento urbano da ASA. Desde o período colonial esses dois núcleos urbanos possuem relações bem próximas, não apenas pelo espaço absoluto (as duas cidades estão geograficamente próximas), mas também pelo espaço relativo e relacional, em função das articulações existentes, em relação à produção e circulação do arroz nessa região durante a segunda metade do século XVIII (MARIN, 2005). 


\section{CENTRALIDADE POLÍTICA DE MACAPÁ}

De fato, o ponto de ignição da centralidade política de Macapá foi à criação do TFA. Ferreira Filho (1975) chama de "estado embrião" para as unidades descentralizadas da administração federal, com autonomia administrativa e financeira. Segundo Porto (2003), os Territórios Federais se apresentam como uma experiência de ações onde não podem ser tomados somente como uma ação política, mas deve-se considerar, também, outros aspectos, como o geopolítico, o jurídico, o econômico, o geográfico, e a ligação com o federalismo.

Destarte, a ação política não se encontra distante, mas em conjunto com outras instancias sociais, no caso do TFA o político anda em consonância com o administrativo, visto o corpo social criado com o número de empregos criados na capital Macapá.

Por apresentar uma importância político-administrativa e econômica com relação ao estado do Amapá e à ASA, a capital amapaense se apresenta, ao mesmo tempo, como articuladora interestadual (rio) e intraestadual (estrada). A partir disto, busca-se compreender o processo das centralidades que vêm ocorrendo na dinâmica espacial da cidade e suas relações construídas ao longo da história na ASA.

Outra forma de pensar a importância de cidades intermediárias na região diz respeito às suas centralidades políticas. Estas não estão restritas apenas aos papéis exercidos por instituições e órgãos oficiais, estaduais e federais, ligados às decisões políticas que nelas se fazem presentes. Tais cidades sediam também importantes forças políticas, associações, representações sindicais, de classe e de categorias sociais diversas, que projetam movimentos de natureza política, tornando-as vitrines de interesses de agentes de peso regional, que, a partir delas, estabelecem projeções de novas territorialidades em nível sub-regional (TRINDADE JR., 2015, p. 324).

A partir da década de 1990, notadamente as cidades de Macapá e Santana, se desenvolvem, tanto no aspecto econômico, quanto no aspecto social e político. Esse desenvolvimento dependeu da melhoria da infraestrutura existente; do processo de diversificação das atividades econômicas; e dos recursos da União, via transferências federais. 0 nível de interações espaciais e de complementariedade urbana entre Macapá e Santana é muito forte e, em 1991 houve a Criação da Área de Livre Comércio Macapá - Santana (ALCMS), a qual promoveu significativo crescimento populacional em Macapá, que passou de 169.579 no referido período para 397.913 habitantes no último censo realizado (IBGE, 2010). Num espaço cronológico, pouco anterior à criação da ALCMS, houve a transformação do Território Federal do Amapá em Estado, a partir da Constituição de 1988, ambos os eventos geraram intensos fluxos migratórios intra e inter-regionais nesse período para o então recém-criado Estado do Amapá.

A nova dinâmica criada com sua estadualização atraiu investimentos junto aos setores da economia, principalmente o terciário, representado pelo comércio e serviços. A criação da ALCMS, pelo decreto-lei $\mathrm{n}^{\circ} 8.387$, de 30 de dezembro de 1991 e regulamentada pelo Decreto ${ }^{\circ}$ 517, de 8 de maio de 1992 cria uma nova diligência para a área. Além deste regime especial aduaneiro, outros foram solicitados para se instalar no Amapá. Três propostas foram apresentadas: A Zona Franca de Macapá (1983), a Zona de Processamento e Exportação de Santana (1989) e a Área de Livre Comércio de Macapá e Santana (1991). Atualmente, o projeto de lei sobre a criação da Zona Franca Verde visa à isenção do Imposto sobre Produtos Industrializados - IPI, bem como, o desenvolvimento de um parque industrial do Amapá composto por grandes empresas e pequenos empreendedores do Estado.

A ALCMS foi um marco na dinâmica econômica regional, tendo em vista o impulso que possibilitou o fluxo comercial de bens e serviços, a partir dos dois principais centros de negócio do estado: Macapá e Santana (AMORIM, 2016). A inserção de empresas importadoras cresceu exponencialmente nesse período e a ALCMS estimulou a instalação dessas empresas no estado do Amapá (Tabela 1).

Tabela 1 - Número de empresas instaladas na ALCMS (1992 - 2000).

\begin{tabular}{lc|c|c|c|c|c|c|c|c|}
\multicolumn{1}{c}{ ANO } & 1992 & 1993 & 1994 & 1995 & 1996 & 1997 & 1998 & 1999 & 2000 \\
ALCMS & 1.007 & 1.325 & 597 & 317 & 363 & 454 & 490 & 479 & 455 \\
CADASTRO & 995 & 307 & 139 & 121 & 145 & 155 & 150 & 122 & 123 \\
RECADASTRO & 12 & 1.018 & 458 & 196 & 218 & 299 & 340 & 357 & 327 \\
$\begin{array}{l}\text { TOTAL NAS } \\
\text { ALC } \\
\text { BRASILEIRAS }\end{array}$ & 1.172 & 1577 & 875 & 493 & 551 & 600 & 644 & 646 & 621 \\
\hline
\end{tabular}


Entre 1990 e 2000, houve uma diferença entre o número de cadastro bastante elevado no início da década de 1990, por conta das novas exigências burocráticas que foram fixadas para instalação de novas empresas e para o seu recadastramento (por exemplo, a certidão negativa dos órgãos federais), assim como também houve a implantação de quotas por cada Área de Livre Comércio - ALC, para adquirir produtos importados (PORTO, 2003).

Entre 2002 e 2015, a SUFRAMA registrou 9.924 empresas em Macapá, no total entre cadastro, recadastro e recadastro sem alteração contratual. Em Santana, foram registradas 1.517 empresas, no mesmo período, o que demonstra a concentração dessas empresas na capital Macapá (AMORIM, 2016). A ALCMS apresentou, entre 2000 e 2015, um grande volume de importações, o que demonstra a importância econômica dessa ALC na economia das duas maiores cidades do estado do Amapá, além dos benefícios fiscais, adotados com a isenção de ICMS - Imposto sobre Circulação de Mercadorias e Serviços, pelas cidades de Macapá e Santana.

\section{CENTRALIDADE SOCIOTERRITORIAL DE MACAPÁ}

Os ribeirinhos, em seu processo de ocupação ao longo da várzea dos rios amazônicos, constituíram um modo de vida bem peculiar e característico a essa região. Sua experiência histórica com os rios e com a floresta os legou práticas e valores que possibilitam a manipulação de ecossistemas extremamente delicados, por meio do desenvolvimento da pesca, da agricultura e do extrativismo.

Figura 2: Mapa da importância de Macapá na rede urbana segundo a REGIC.

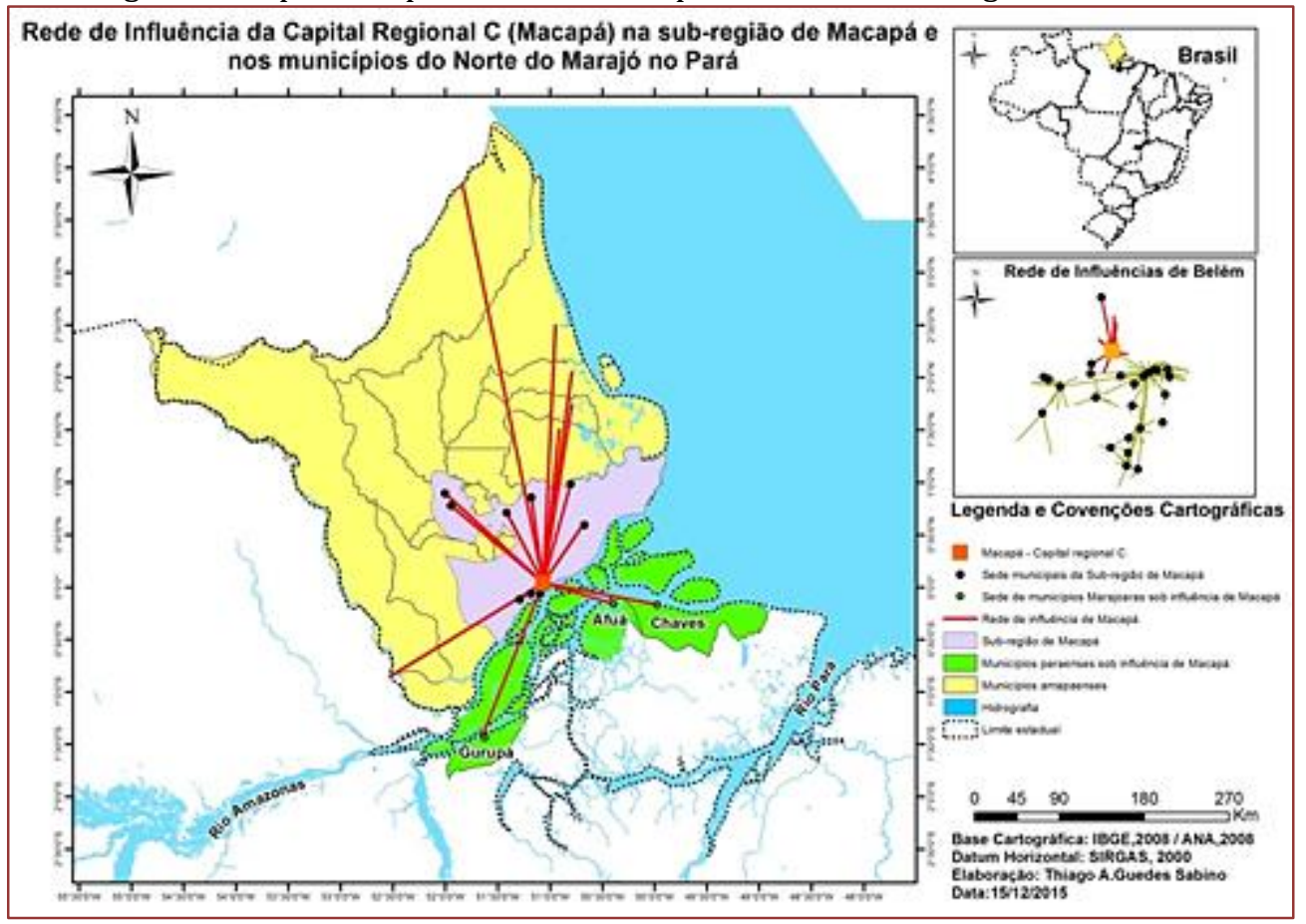

Fonte: regic, 2018.

Macapá é uma das 64 cidades que, segundo a REGIC (2018)(ver Figura 2), se encontra na condição de capital regional C. Quando se considera a gestão pública para demonstrar o nível de centralidade, Macapá fica atrás apenas das metrópoles Manaus e Belém na região Norte, critério no qual o arranjo populacional de Brasília/DF se encontra isolada como maior nível.

A capital amapaense ocupa o terceiro lugar no critério de Coeficiente de intensidade e centros de gestão empresarial, segundo as Unidades da Federação, onde as capitais estaduais se destacam, todavia, na gestão do território Macapá aparece ao lado de Belém, Marabá, Manaus, Porto Velho, Rio Branco e Boa Vista com nível de centralidade 2 , na região Norte.

O detalhe dos dados da REGIC (2018) é que apenas no quesito Deslocamentos para compras de móveis e eletroeletrônicos surgem às conexões com a face norte da ilha de Marajó com a capital Macapá, fato esse 
que representa de forma isolada a estatística de relações entre a capital tucujú e a dinâmica urbano ribeirinha setentrional da Amazônia. Percebe-se que os dados da REGIC são limitados quando da análise dessa dinâmica, devido à própria metodologia do estudo ser baseada em questionários aplicados nas principais cidades e sem levar em conta a dinâmica espacial mais peculiar do rio.

O rio, que tem importância fundamental para a vida do homem ribeirinho amazônico, corresponde a uma referencia central em sua organização espacial, em seu ritmo social e no seu imaginário (mitos, lendas, crenças e cosmogonias). Nesse modo de vida, o rio não significa apenas um principal acidente geográfico, mas o meio de subsistência, de comunicação e de transporte, das pessoas, ou ainda, a mediação entre os significados e representações do imaginário social.

Neste sentido, o rio que comanda a vida aparece como elemento, na qual uma rede articulada se construiu ao longo do tempo, principalmente a partir das de Macapá e Santana com as ilhas do golfão marajoara (Figura 3).

A rede, enquanto realidade material pode ser entendida como toda infraestrutura que permite o transporte de matéria, de energia ou de informação e que se inscreve sobre um território, o qual se caracteriza pela topologia de seus pontos de acesso ou pontos terminais, seus arcos de transmissão, seus nós de bifurcação ou de comunicação. Na perspectiva de dado social, a rede é preenchida por valores sociais, políticos e mensagens das pessoas em geral, pois, sem isso, a dimensão material da rede perante nossos sentidos seria apenas uma mera abstração (SANTOS, 2006). Essa distinção das dimensões material e social das redes se constitui de forma dialética, onde os objetos técnicos presentes apresentam funções sociais historicamente construídas.

No caso da Amazônia, apesar de existir uma rede técnica materialmente consolidada, em função da utilização do transporte rodoviário, a mesma região possui uma conexão imaterial pautada nas suas relações com rio (material, cultural e simbólica), de forma que, sua população usufrua deste elemento natural em sua totalidade.

Figura 3: Portos e atividades ligadas à dinâmica ribeirinha em Macapá e Santana.
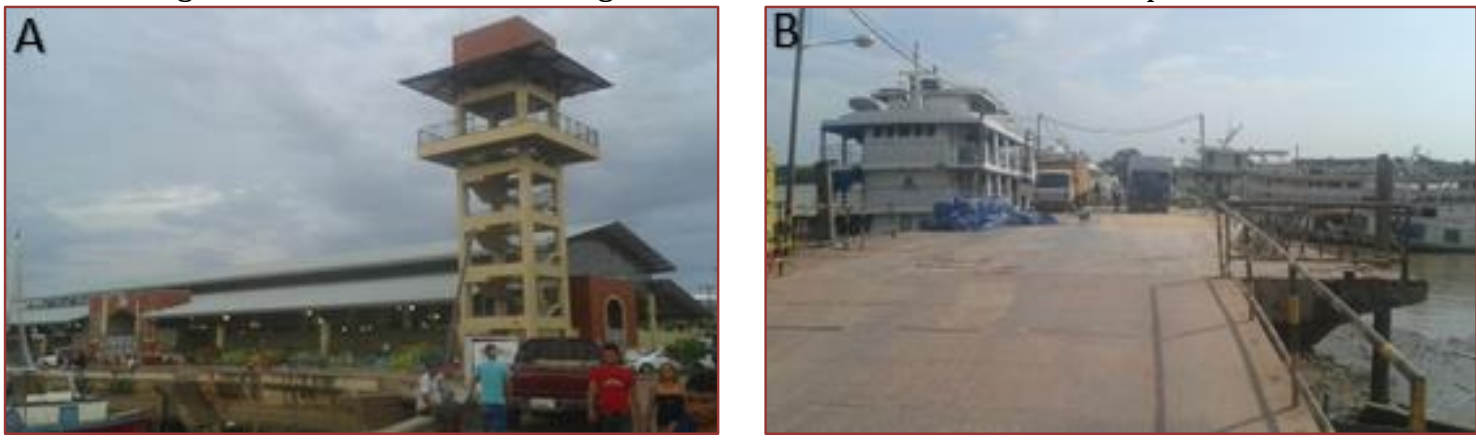

Descrição: A) Mercado de pescado do Igarapé das Mulheres (Macapá/Ap); B) Porto do Grego (Santana/Ap). Fonte: Pesquisa de campo, 2020.

Um bom exemplo dessa rede imaterial e simbólica é a cidade de Afuá que, mesmo pertencendo administrativamente ao Estado do Pará, possui relação comercial mais intensa com Macapá, capital do Amapá. Sua proximidade geográfica, crescimento populacional e econômico gerou também novas demandas e ofertas no abastecimento de Afuá, como a introdução de produtos de outras regiões, tais como alimentos congelados, enlatados, frutas e hortaliças que não são produzidas na região: uvas, brócolis, maçãs, peras, etc., comercializados nos estabelecimentos da cidade (LOMBA e NOBRE JR, 2013).

Ao lado da capital amapaense, a cidade de Santana cumpre importante papel na rede urbana mais setentrional, pois a maior parte dos portos que recebem indivíduos das ilhas da foz do Amazonas e de outros municípios mais distantes se encontram nos Portos do Grego, Porto Souza Mar, Porto da Ilha de Santana, além dos portos em Macapá Píer do Santa Inês.

Os portos servem tanto como pontos de entrada e saída de pessoas e mercadorias, como criam uma rede de atividades voltadas em torno dessa dinâmica, como é o caso das feiras de pescado do Igarapé das Mulheres, o Mercado central de Macapá, a feira do Igarapé da Fortaleza, dentre outros. 
A dinâmica de pessoas possui alcance espacial relativamente grande, apesar de Macapá ser capital regional C e Santana centro local (REGIC, 2018), pois, segundo Silva (2017), no embarque/desembarque dos portos santanenses, em primeiro lugar, aparece à metrópole de Belém, em seguida Santarém e Breves, dentre outros igarapés e canais localizados na orla de Macapá, que por sua vez, servem para carga e descarga de produtos regionais, oriundos principalmente de cidades do arquipélago paraense, tais como Afuá, Breves, Chaves e Gurupá. 0 embarque e desembarque de pessoas na orla fluvial de Macapá conta-se com o porto da orla do Bairro Santa Inês, com uso sazonal, em especial quando há o tradicional festival do camarão em Afuá

Os elementos em conjunto dão à cidade de Macapá, e de forma indireta à cidade de Santana a chamada centralidade socioterritorial, por apresentar influência na rede de relações material e imaterial junto aos municípios paraenses da foz do Amazonas e no interior do estado amapaense uma dinâmica interessante e portadora de verdadeiros "nós" na rede urbana setentrional amazônica.

\section{CONSIDERAÇÕES FINAIS}

A cidade de Macapá, no estado do Amapá apresentou em seu contexto de formação socioespacial a passagem de uma centralidade política para uma centralidade socioterritorial. Nesse sentido, exalta-se a importância de compreender de como se constitui a centralidade da cidade de Macapá em conjunto com a cidade de Santana, no contexto urbano e regional, principalmente, a partir da década de 1990 quando do desmembramento do município de Santana de Macapá.

A vizinha da capital possui uma importância, no que tange à sua rede portuária, onde a dinâmica ribeirinha com as duas cidades é intensa. As populações ribeirinhas buscam Macapá e Santana devido sua proximidade territorial na intenção de atendimento de serviços de saúde, comércio, venda e troca de produtos regionais e de educação.

Uma centralidade construída desde os tempos da Companhia de Comércio do Grão-Pará e Maranhão, onde a capital servia de entreposto comercial junto à cidade de Belém, passando por sua emancipação político administrativa, chegando até os dias atuais, sem perder a ligação com o rio. 0 espaço amazônico possui essa peculiaridade em tempos de modernidade, redes logísticas intensas, através de rodovias e aeroportos, mas ainda muito viva a presença da conexão com o rio, através das comunidades ao longo dos rios, furos e igarapés da vasta bacia hidrográfica amazônica.

\section{AGRADECIMENTOS}

A Coordenação de Aperfeiçoamento de Pessoal em Nível Superior (CAPES) pelo financiamento desta pesquisa junto ao programa de pós-graduação em Geografia.

\section{REFERÊNCIAS}

[1] AMARAL, Márcio Douglas B. Dinâmicas econômicas e transformações espaciais: a metrópole de Belém e as cidades médias da Amazônia Oriental - Marabá (PA) e Macapá (AP). Tese (Doutorado em Geografia) - Faculdade de Filosofia Letras e Ciências Humanas, Universidade de São Paulo, São Paulo, SP, Brasil, 2010.

[2] AMORIM, J. P. A. Organização espacial da sub-região de Macapá, na Amazônia Setentrional Amapaense (1990-2015). Dissertação (Mestrado em Desenvolvimento Regional) - Universidade Federal do Amapá, Macapá, 2016.

[3] BITOUN, J. Em busca de especificidades da cidade e do urbano no Brasil. In: Geografia urbana: desafios teóricos contemporâneos. SERPA, A; CARLOS, A. F. A (Orgs.). Salvador: EDUFBA, 2018.

[4] CORREA, R. L. Redes geográficas: reflexões sobre um tema persistente. Cidades, São Paulo, v. 9, n. 16, p. 199$218,2012$.

[5] DIAS, Manuel Nunes. A Companhia Geral do Grão Pará e Maranhão (1775-1778). Belém: UFPA, 1970. (Coleção Amazônica, Série José Veríssimo).

[6] FERREIRA FILHO, M. G. Curso de direito constitucional. 22 ed. São Paulo: Saraiva, 1975.

[7] IBGE. Instituto Brasileiro de Geografia e Estatística. Regiões de influência de cidades 2007. Rio de Janeiro. IBGE. 2008.

[8] Censo demográfico 2010. Disponível em: <http://www.censo2010.ibge.gov.br >. Acesso em 20/07/2020. 
[9] Instituto Brasileiro de Geografia e Estatística. Regiões de influência de cidades 2007. Rio de Janeiro. IBGE. 2018.

[10] LEFEBVRE, Henri. A revolução urbana. Belo Horizonte: Editora UFMG, 1999.

[11] LOMBA, R. M; NOBRE-JÚNIOR, B. B. A relação rural-urbano a partir das cidades ribeirinhas: o papel do comércio popular (feiras) na cidade de Afuá (PA). Confins [Online], n. 18, 2013.

[12] MARIN, R. E. A. Prosperidade e Estagnação de Macapá Colonial: experiências dos colonos In: GOMES, Flávio dos Santos. Nas terras do Cabo Norte - fronteiras, colonização e escravidão na Guiana brasileira - Séc. XVIII/XIX (org.). Belém: Ed. UFPA, 1999.

[13] Agricultura no delta do rio Amazonas: colonos produtores de alimentos em Macapá no período colonial. Novos Cadernos NAEA. Belém-PA, v. 8, n. 1, p.73-114, jun. 2005.

[14] OLIVEIRA JÚNIOR, Gilberto A. de. Redefiniçao da centralidade urbana em cidades médias. Revista Sociedade e Natureza. v. 20, n. 1, p. 205-220. Uberlândia, 2008.

[15] PORTO, J. L. R. Amapá: Principais transformações econômicas e institucionais (1943-2000). Macapá: SETEC, 2003.

[16] Desenvolvimento Geográfico Desigual da faixa de fronteira da Amazônia setentrional brasileira: Reformas da condição fronteiriça amapaense (1943- 2013). (Tese de Pós-Doutorado). Porto: Blumenau, FURB/PPGDR, 2014.

[17] QUEIROZ, J. M. História, mito e memória: o Cunani e outras repúblicas. In: GOMES, Flavio dos santos (Org.). Nas terras do Cabo Norte: Fronteiras, colonização e escravidão na Guiana Brasileira - séculos XVIII/XIX. Belém: EDUFPa, 1999.

[18] REIS, A. C. F. Território do Amapá: perfil histórico. Rio de Janeiro: Imprensa Nacional, 1949.

[19] SANTOS, M. A Natureza do Espaço: Técnica e Tempo, Razão e Emoção. 4 ed. 2. reimpr. - São Paulo: Edusp, 2006.

[20] SANTOS. E. R. C. Amazônia Setentrional Amapaense: do "mundo" das águas às florestas protegidas. Tese (Doutorado), FCT-UNESP, Presidente Prudente, São Paulo, SP, Brasil, 2012.

[21] SANTOS, R. V. Estruturação e Formação do Aglomerado Urbano de Macapá e Santana na Amazônia Setentrional Amapaense. Dissertação (Mestrado em Desenvolvimento Regional) - Universidade Federal do Amapá, Macapá - 2016

[22] SANTOS, R. V; AMORIM, J. P. A. A centralidade urbana sub-regional de Macapá-Ap e sua região de influência. Anais: XVI Encontro Nacional da Associação Nacional de Pós-Graduação e Pesquisa em Planejamento Urbano e Regional. Realizado em Belo Horizonte, de 18 a 25 de maio de 2015. Belo Horizonte - MG, 2015.

[23] SPÓSITO, M. E. B. Segregação socioespacial e centralidade urbana. In: CORRÊA, R.L.; PINTAUDI, S. M.; VASCONCELOS, P. A (Orgs.). A cidade contemporânea: segregação espacial. São Paulo: Contexto, 2013.

[24] SUFRAMA. Interiorizando o desenvolvimento no Estado do Amapá. Disponível em:

<http://www.suframa.gov.br/publicacoes/interiorizando/amapa.pdf>. Acesso em: 20 jul. 2020.

[25] Contratos de fornecedores firmados entre 2002 e 2011. Disponível em:

<http://www.suframa.gov.br/suframa_descentralizadas_alcs_macapasantana.cfm>. Acesso em: 20 jul. 2020.

[26] TRINDADE JR. S-C. Pensando a modernização do território e a urbanização difusa na Amazônia. Mercator. Fortaleza Online, v. 14, p. 93-106, 2015.

[27] Por outras centralidades: pensando especificidades e particularidades da cidade e do urbano no Brasil. In: Geografia urbana: desafios teóricos contemporâneos. SERPA, A; CARLOS, A. F. A (Orgs.). Salvador: EDUFBA, 2018.

[28] TRINDADE JÚNIOR, S-C; MADEIRA, W. do V. Polos, eixos e zonas: cidades e ordenamento territorial na Amazônia. PRACS: Revista Eletrônica de Humanidades do Curso de Ciências Sociais da UNIFAP, Macapá, v. 9, n. 1, p. 37-54, jan./jun. 2016. 


\section{Capítulo 9}

\section{A Produção do Espaço Urbano: Análise geográfica do bairro Flutuante na cidade de Tapauá-AM}

\section{Abraão Ferreira Zuza}

\section{Eubia Andréa Rodrigues}

Resumo: 0 presente trabalho tem como objetivo compreender os tramites sociais na produção do espaço urbano fluvial na cidade de Tapauá-AM, esta compreensão foi possível a partir da análise espacial, observações diretas e entrevistas com os moradores, entendendo que o diálogo é necessário para compreender os anseios e angustias dos envolvidos, buscou-se informaç̃es nas instituições municipais sobre a legalidade da inserção dos flutuantes no rio. Portanto, a falta de planejamento deu a origem a um novo bairro formado por pescadores e agricultores que migraram para a cidade na busca por melhores condições de vidas. Existem empresários que se apropriam do espaço fluvial inserindo flutuantes como pontos comerciais, devido o fluxo de pessoas, constatou-se ainda denominações religiosas também se fazem presente nesse espaço.

Palavras chave: Espaço urbano, Flutuantes, Tapauá. 


\section{INTRODUÇÃO}

A Região Amazônica possui uma quantidade considerável de suas populações humanas habitando as margens dos rios, nas localidades denominadas de comunidades ribeirinhas, que são formadas por uma grande extensão territorial chamadas de várzea e terras firmes, ocorrendo anualmente os fenômenos naturais denominados de enchente e vazante.

Nesse sentindo, os ribeirinhos são afetados frequentemente pela água, sendo necessário aprender a conviver com os impactos ambientais, como erosão do solo e terras caídas.

É relevante ressaltar que os recursos públicos como Bolsa Família e Luz para todos, destinados para essas populações não são suficientes para o suprimento de suas demandas, tendo em vista, que a enchente ocorre em um período aproximadamente de seis meses, esta sazonalidade tem propiciado um desconforto quanto à produção que é afetada por essa dinâmica.

Na tentativa de não serem afetados de forma que venham ter maiores prejuízos, muitos migram para os centros urbanos, essa ideia é associada com a busca de inserir os filhos na escola e adquirirem melhores condições de vida, considerando que, muitas comunidades ribeirinhas não oferecem esses recursos e nem meios adequados para que eles sejam conquistados.

Surge então à necessidade de buscar novas formas de sobrevivência em direção as cidades, são construídas então casas flutuantes ${ }^{15}$, tipo de moradia, que dentre suas vantagens está a de ser móvel, com o auxilio de barcos, os flutuantes são transportados e instalados nas margens dos rios.

O município de Tapauá possui uma grande extensão territorial, se caracterizando como um dos maiores do estado, no entanto, a área urbana do município apesar de possuir apenas 59 anos do inicio de sua formação sócio espacial, apresenta características de limitação, pois grande parte da área territorial, sobretudo a que fica próxima à área urbana, é comandada pela Fundação Nacional do Índio (FUNAI).

Há a necessidade de realizar um discurso sobre as categorias do urbano, diante do crescimento elevado do número de flutuante e das atividades desenvolvidas, relações sociais e características contidas nesse espaço. Entende-se que a produção do espaço urbano fluvial de Tapauá-AM deu origem à um novo bairro na cidade.

Portanto, o presente artigo busca compreender os dramas sociais na produção do espaço urbano fluvial pelas casas flutuantes na cidade de Tapauá-AM, para tanto, foi necessário analisar as condições de vida dos moradores das casas flutuantes e os principais problemas enfrentados por eles, verificou-se quem são e qual a origem dos moradores, identificou-se as principais causas que levam as pessoas a procurarem esses lugares para morar, analisou-se a posição do poder público sobre o assunto e quais os serviços de assistência social para os residentes, descrevendo os principais problemas ocasionados pelo número exagerados de flutuantes.

Tendo como base informações transmitidas pelos moradores, que foram coletadas através do sistema de entrevistas, observação direta, teve-se ainda acesso ao plano diretor municipal onde estão contidas diversas alternativas de habitação.

Para a realização desse trabalho, dividiu-se os procedimentos em três etapas, na primeira etapa desenvolveu-se um levantamento teórico sobre autores que estudam o espaço urbano, em seguida houve a elaboração de questionários e entrevistas partindo assim, para a parte prática através da pesquisa de campo, primeiramente com observações de diferentes lugares da área urbana fluvial do município de Tapauá-AM, podendo analisar os locais onde o aglomerado de flutuantes é em maior número, e constatar o intenso tráfego de veículos aquáticos.

Posteriormente iniciou-se a segunda etapa, o processo de conversas com os moradores e a aplicação do questionário, manteve-se conversas com pessoas que moram há pouco tempo e com moradores mais antigos. Para essa etapa foram preciso cinco idas a campo para a aplicação de entrevistas e registros de fotos. Na terceira etapa buscou-se informações nos órgãos públicos do município, tendo como foco principal a prefeitura, a câmara e o cartório, visto que a Capitania dos Portos não está presente no município.

\footnotetext{
${ }^{15}$ Tipo de moradia fluvial muito comum na Amazônia, construída sobre um tronco de árvore flutuante, típica da região, possui a vantagem de ser móvel.
} 


\section{A PRODUÇÃO DO ESPAÇO URBANO}

É necessário que se tenha uma concepção sobre o espaço como categoria de análise, e posteriormente destacar o espaço urbano, nesse sentido, Santos (2006, p. 21) esclarece que: "Como um ponto de partida, propormos que o espaço seja definido como o conjunto indissociável de sistemas de objetos e de sistema de ações". Entende-se que os objetos são elementos fundamentais no processo de produção do espaço urbano, vinculado a isso estão às ações que possibilitam toda dinâmica existente, visto que, o urbano não é estático.

O espaço, assim, é um das principais categorias de análise mais importantes da ciência geográfica, para se desenvolver uma discussão sobre o urbano, é necessário que seja feita uma abordagem sobre sua definição, e seu papel frente às contradições existentes. Assim Moreira (2011 p. 63) diz que: "O espaço é o objeto da geografia. 0 conhecimento da natureza e das leis do movimento da formação econômico-social por intermédio do espaço é o seu objetivo".

Torna-se essencial desenvolver uma reflexão a respeito das divisões de classes, fato comum frente à imposição do sistema capitalista, é essencial entender que existe sempre uma relação de poder que possibilita a produção de novos espaços, Moreira (2011, p. 62) argumenta que:" É nossa opinião que por detrás de todo arranjo espacial estão relações sociais, que nas condições históricas do presente são relações de classes".

Compreende-se assim, que existe uma mútua relação entre as relações sociais e o arranjo espacial, com base nisso, surgem às divisões desiguais, e alguns dos resultados que são reflexos dessa desigualdade encontra-se a fragmentação do urbano, em que os trabalhadores de baixa renda, não possuem alternativas satisfatórias de moradias e acabam construindo casas em áreas de riscos, ou em periferias.

O espaço urbano torna se aliado do sistema capitalista, nesse sentido ocorre o que é conhecido como divisão de classes, onde grandes quantidades das riquezas estão nas mãos de uma considerável minoria, assim, por intermédio do capital a força de trabalho é cada vez mais explorada, o ser humano é obrigado a se adequar as normas impostas pelo sistema, este por sua vez impõe a ideia de que a cidade é lugar ideal para se viver, assim pode-se constatar que a sociedade vive em um processo de completo dinamismo, do mesmo modo o espaço urbano também é dinâmico, sujeito a alterações com frequência, Corrêa (1989, p. 8) argumenta que:

Dois pontos devem ser indicados. Primeiramente por ser reflexo social e fragmentado, o espaço urbano, especialmente o da cidade capitalista, é profundamente desigual: a desigualdade constitui-se em característica própria do espaço urbano capitalista. Em segundo lugar, por ser reflexo social, e porque a sociedade tem a sua dinâmica, o espaço urbano também é mutável, dispondo de uma modalidade que é complexa, com ritmos e natureza diferenciados.

Portanto, o espaço urbano é formado a partir de uma perspectiva baseada no reflexo social, ou seja, as contradições existentes contribuem para que esse espaço seja produzido, com isso, a cidade partindo do ponto de vista capitalista, é desigual, em diversos sentidos, sobretudo na divisão do espaço destinado a construção de moradias. Isso reflete também na produção do espaço urbano, onde as cidades ficam cada vez mais limitadas, e a concorrência por território aumenta. Assim, Sposito (2014, p. 30) esclarece que: "a cidade nunca fora um espaço tão importante, e nem a urbanização um processo tão expressivo e extenso a nível mundial, como a partir do Capitalismo".

Nessa perspectiva, existe uma mútua relação entre o crescimento das cidades e o sistema capitalista, pois, esse sistema em sua essência trouxe novas alternativas para a obtenção de lucros, em todos os âmbitos sociais, dessa forma, a cidade exerce papel fundamental para a prática de funções inovadoras, e que possibilitam a seus habitantes desenvolverem atividades contemporâneas.

Mesmo com a ideologia capitalista e a divisão de classes, a cidade passa a ser um direito daqueles que desejam usufruir dos benefícios que nela estão contidos, mas, como já esclarecido, esses bens são divididos de forma desigual. Sobre o direito a cidade Lefebvre (2001, p. 117) ressalta que: "O direito a cidade não pode ser concebido como um simples direito de visita ou de retorno às cidades tradicionais. Só pode ser formulada como o direito a vida urbana transformada, renovada." 
Entende-se, que apenas o ato de visitar não está incluído no direito a cidade, esse direito é concebido quando se tem uma nova dinâmica de vida, ou seja, o desenvolvimento de novas atividades, pois, sabe-se que a partir da inserção no espaço urbano o indivíduo passa a conviver com novos elementos, dotados de uma nova configuração imposta pelo sistema, tendo como base que esses elementos variam de cidade para cidade e dependem de alguns fatores característicos, como tamanho da população e tamanho do espaço urbano, mas é certo que eles existem e proporcionam aos cidadãos novas opções de vida.

Tratando de um contexto histórico as cidades evoluíram em um sentido global, dando com isso mais alternativas para a produção do espaço urbano. Para se entender a produção do espaço urbano fluvial na cidade de Tapauá-AM, é necessário fazer, inicialmente, uma reflexão de como esse espaço foi formado, ou o que levou a sua formação, que motivos levam as pessoas migrarem do campo para a cidade, para tanto, é necessário que se tenha uma visão sobre o espaço urbano, em uma escala global e local, onde Lefebvre (2001, p. 105) argumenta que:

Trata-se da necessidade de uma atividade criadora de obra (e não apenas de produtos e de bens materiais consumíveis), necessidades de informação de simbolismo, de imaginário, de atividades lúdicas. Através dessas necessidades especificadas vive e sobrevive um desejo fundamental, do qual o jogo, a sexualidade, os atos corporais tais como o esporte, a atividade criadora, a arte e o conhecimento são manifestações particulares e momentos, que superam divisão parcelar dos trabalhos.

Mesmo em meio as contradições, o homem vive em constantes necessidades, a sociedade evolui, permitindo com que ele tenha acesso a novos meios que lhe trazem facilidades em diferentes áreas de sua vida, surgem assim, os meios tecnológicos através de equipamentos portadores de sistemas de internet, atividades recreativas que só são possíveis de serem desenvolvidas em grupos, ainda pode-se citar as atividades de cunhos religiosos, além disso, existe a carência do acesso a escola, no que se refere à Amazônia a educação escolar não se faz presente em muitas comunidades ribeirinhas, e quando se faz é de forma precária.

$\mathrm{Na}$ maioria das vezes o pequeno produtor que vive no espaço rural, sobrevivendo basicamente da agricultura e da pesca se sente limitado, as alternativas de crescimento são poucas, pois a melhores escolas, melhores sistemas de saúde, bancos, e comércio como um todo se fazem presente na cidade. Dando uma definição objetiva sobre o espaço urbano Lefebvre (1999, p. 28) destaca que:

O urbano (abreviação de sociedade urbana) define-se, portanto não como realidade acabada, situada, em relação a realidade atual, de maneira recuada no tempo, mas, ao contrário, como horizonte, como virtualidade iluminadora. 0 urbano é o possível, definido por uma direção, no fim do percurso que vai em direção a ele.

O urbano está sempre em um processo de evolução, sujeito a transformações, ou seja, o lugar onde está ocorrendo sua produção está sempre sujeito a mudanças devido à dinâmica da urbanização, tendo em vista que com a expansão do fenômeno da migração a cidade tem se tornado cada vez mais a opção das pessoas em busca de novas condições de vidas, a transformação é visível dentro de um contexto de produção.

O urbano, não está em um estado concluído, ele é o possível, ou seja, existe sempre uma nova maneira de se urbanizar criação de novas ruas, novos bairros, dependendo da intensidade em que a dinâmica ocorre, a busca por novos horizontes trás possibilidades para a produção desse espaço. Santos (2006, p. 61) esclarece que: "os elementos fixos, fixam em cada lugar, permitem ações que modificam o próprio lugar. Fluxos novos ou renovados que recriam as condições ambientais e as condições sociais redefinem o lugar".

Contextualizando com Tapauá, embora os flutuantes não sejam objetos fixos, suas presenças permitem o surgimento de fluxos, que estão vinculados a uma lógica espacial onde as relações humanas ocorridas, trazem contradições que são características da produção do urbano. E isso possibilita uma redefinição do lugar, com novas pessoas, novos objetos, novas ações e novas relações, pois, todos os dias pessoas trabalham, e circulam no espaço onde os flutuantes estão inseridos, se apropriando e desenvolvendo atividades que podem ser definidas como fluxos.

Santos (2001, p. 197) diz que “Cada vez que há uma mudança tecnológica profunda, uma mudança organizacional profunda, uma mudança social profunda, os modelos de percepção da realidade mudam substancialmente". 
Compreende-se que a produção do espaço urbano está aliada as mudanças tecnológicas, que fragmentam em diferentes âmbitos sociais, gerando uma série de mudanças, surgindo frente a isso uma nova percepção que possibilita as pessoas, a desenvolverem uma nova compreensão do espaço, e aliada a ideologia capitalista passam a terem uma nova visão, e, buscarem se inserir nos meios que lhes trazem satisfação.

Isso significa que essas modificações possibilitam novas maneiras de agir, de se relacionar e se referindo à vida nas cidades, a dinâmica que nela está contida trás consigo alternativas de trabalhos, moradias, no entanto, não possuem uma divisão igual dos bens e serviços disponíveis.

Falando em termos da produção do espaço urbano no território brasileiro Martins (1992, p. 24) esclarece que: "As vilas cresciam lentamente, povoar o Brasil parecia uma tarefa impossível, era preciso trazer mais portugueses para cá e construir cidades, assim decidiu o rei de Portugal”.

Assim, em alguns casos o processo de urbanização do território brasileiro se deu em um processo lento, inicialmente com a formação das vilas, foi necessário a interferência do governo português, pois o Brasil estava no período de colonização, onde a exploração dos principais recursos naturais necessitava de muita mão de obra, assim tornou-se obrigatório a vinda de mais portugueses.

\section{O ESPAÇO URBANO NA AMAZÔNIA}

Na Região Amazônica a produção do espaço urbano seguiu padrões normais, a ocupação dos lugares, no entanto, não teve o mesmo processo das demais regiões do país, ocorrendo com isso em um sentido menos veloz, assim, as contradições sociais e as lutas de classes se fazem presentes e contribuem para que o espaço continue em um ritmo de produção, as relações sociais dão origem a novas formas de vidas e sobrevivências, buscando se adaptar as normas impostas pelo sistema. Sobre essas novas formas de vidas Oliveira (2000, p. 31) diz que:

A produção do espaço na Amazônia cria possibilidades de novos modos de vida resultantes do embate entre as várias formas de relações sociais imbricadas no novo e no velho que se opõem, se contradizem e se completam, dando origem a outras formas de viver.

Na busca constante pelo desenvolvimento o ser humano dá origem a novas formas de viver, entende-se que, devido os períodos sazonais ocorridos na Amazônia, é necessário sempre buscar alternativas de sobrevivência, visando o bem estar socioeconômico, considerando que os sistemas de trabalho sofrem alterações consideráveis tanto no período da enchente quanto da vazante.

As casas flutuantes são uma das alternativas encontrada para a dinâmica local, sobretudo no que se refere à migração dos ribeirinhos para a cidade, esse tipo de moradia possui estrutura adequada, para os impactos e dinâmicas ambientais da região, se tornando assim ajustadas de mobilidade, além disso, oferece os suportes para se adaptar aos processos ambientais ocorridos, sendo assim, passam a ser frequente nas cidades amazônicas, contribuindo diretamente na produção do espaço urbano da região, no entanto essa ideia de ser adequada não é unanime, tendo em vista que sua estrutura não disponibiliza de um sistema de fossas satisfatório.

O rio exerce um papel fundamental na produção do espaço urbano na região Amazônica, sua dinâmica é sempre levada em consideração pelos moradores, assim ele influência diretamente no processo de migração do rural para urbano.

Tocantins (2000, p. 39) afirma que: “É que a água ocupa o primeiro lugar entre os agentes de dinamismo geológico na Amazônia. 0 trabalho do Amazonas e dos rios de sua bacia vai desde a erosão ao transporte e á deposição de resíduos em alta escala". Os resíduos também são provenientes do descarte de material depositado pelo homem no leito dos rios, assim, a urbanização tem contribuído com este processo, tendo como aliado o consumismo, que vem se intensificando desde o período extrativo do látex. 
Figura 01: Casa Flutuante na cidade de Tapauá-AM.

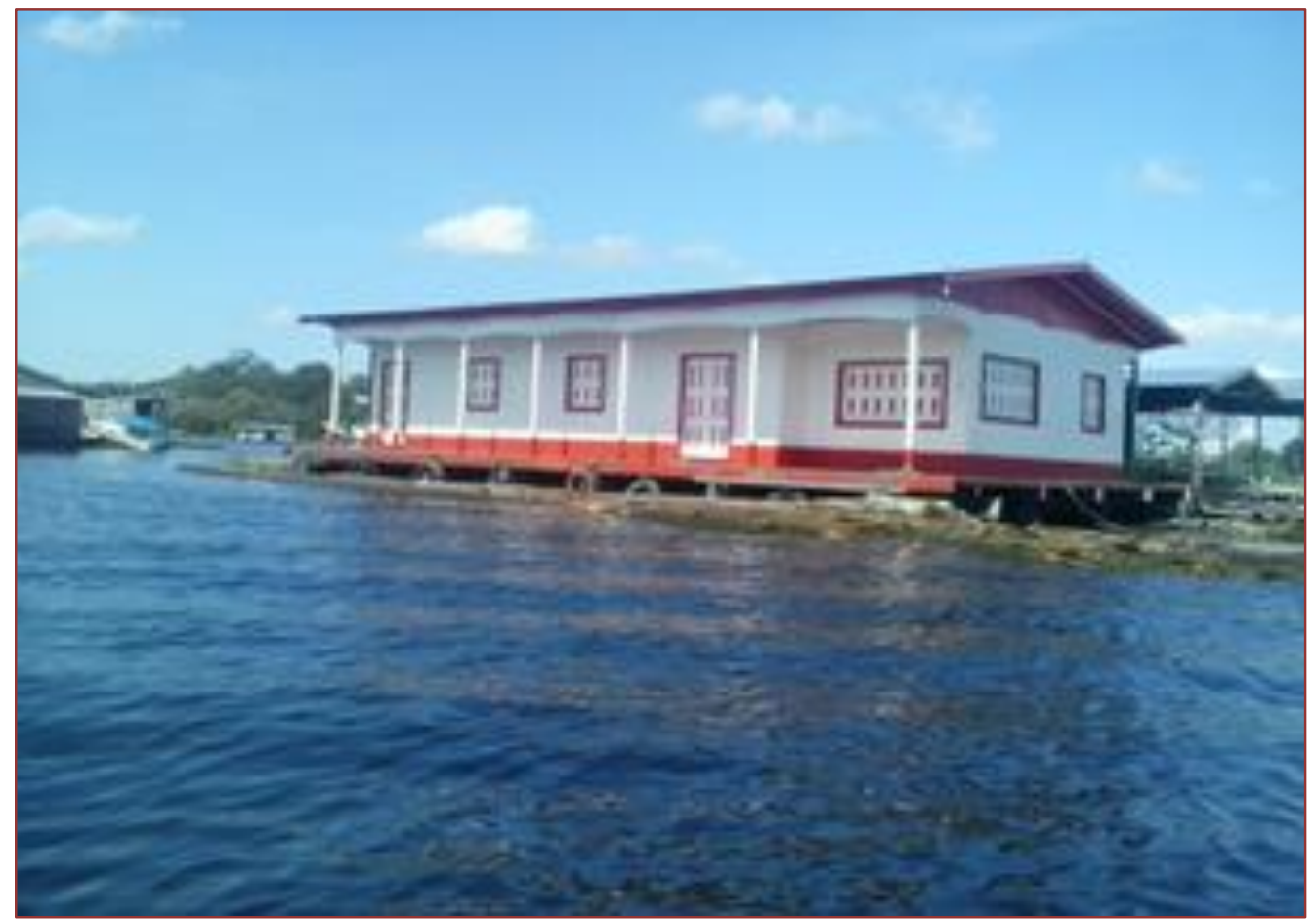

Org. ZUZA (2015)

As cidades da Amazônia possuem particularidades, sobretudo no que diz respeito as suas origens e desenvolvimentos como cidade, ou seja, essas particularidades estão totalmente ligadas em suas formações sócio espaciais, Castro (2008, p. 26) diz que:

As cidades na Amazônia revelam diferenças que nos permitem entendê-las como um espaço socioeconômico e cultural complexo, cuja diversidade tem raízes certamente na história dos lugares e das relações sociais estabelecidas em sua trajetória.

Compreende-se que as cidades na Amazônia são espaços socioeconômicos, cuja as explicações para os seus desenvolvimentos estão em suas origens, deve-se levar em consideração os aspectos históricos. Existe um conjunto de fatores que são distribuídos nos diferentes espaços, possibilitam um entendimento sobre a origem das cidades amazônicas, pode-se perceber que os lugares possuem explicações diferenciadas em suas urbanizações, tendo em vista que existem demandas e aspectos de características próprias, surgem às relações sociais especificas que dão origens a novas formas de vidas de acordo com o lugar, pois ressalta-se, que cada núcleo urbano possui suas características próprias em seu contexto histórico particular.

\section{TAPAUÁ: UMA ANÁLISE DO BAIRRO FLUTUANTE}

Para realizarmos uma discussão sobre a cidade é necessário destacar o município, levando em consideração que no Brasil, especificamente na Amazônia, as cidades, sedes municipais, possuem o mesmo nome do munícipio. A cidade de Tapauá-AM teve seu processo de urbanização iniciado a partir de meados da década de 50, o município que antes era parte integrante do município de Lábrea, passou a ter uma sede própria, localizada a $450 \mathrm{~km}$ em linha reta de Manaus. Atualmente possui uma área territorial de 89.324.259 km², e uma população de 19077 habitantes. 
Figura 02: Mapa e vista aérea da cidade de Tapauá-AM

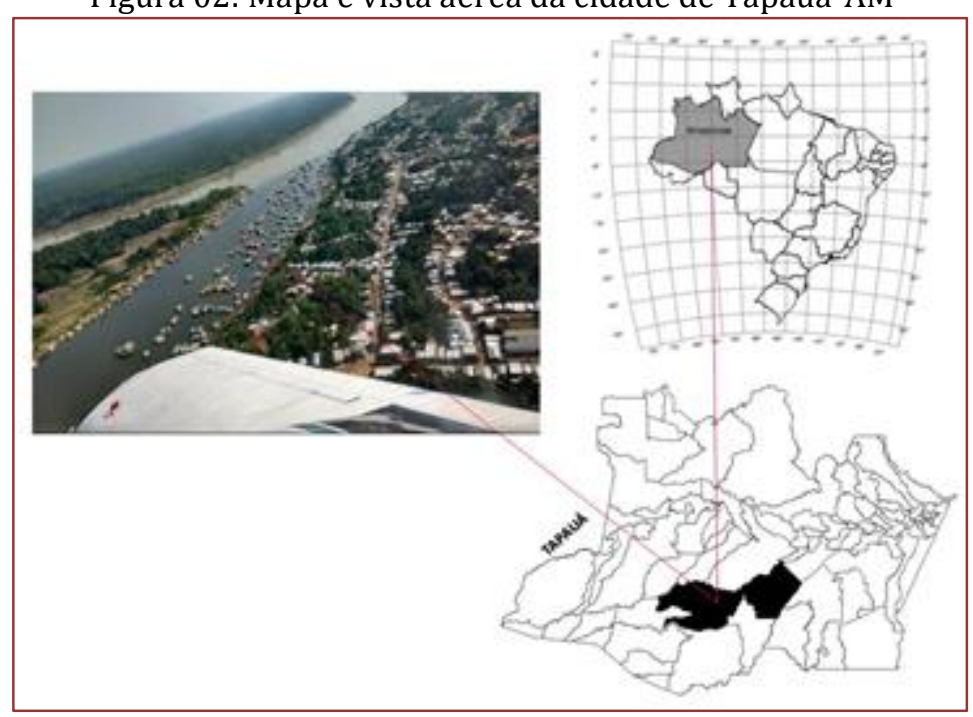

Fonte: Google (2016).

Devido à insuficiência na superfície da cidade, a produção do urbano tem se expandido para área fluvial, onde as casas flutuantes ocupam grande parte do rio na qual a sede do município está inserida, dando origem a uma nova dinâmica de vida para navegantes e moradores, além disso, a cada ano a paisagem é modificada, visto que, flutuantes são construídos para diversas atividades e funções, e ainda outros chegam da zona rural.

Figura 03: Casas Flutuantes na cidade de Tapauá-AM.

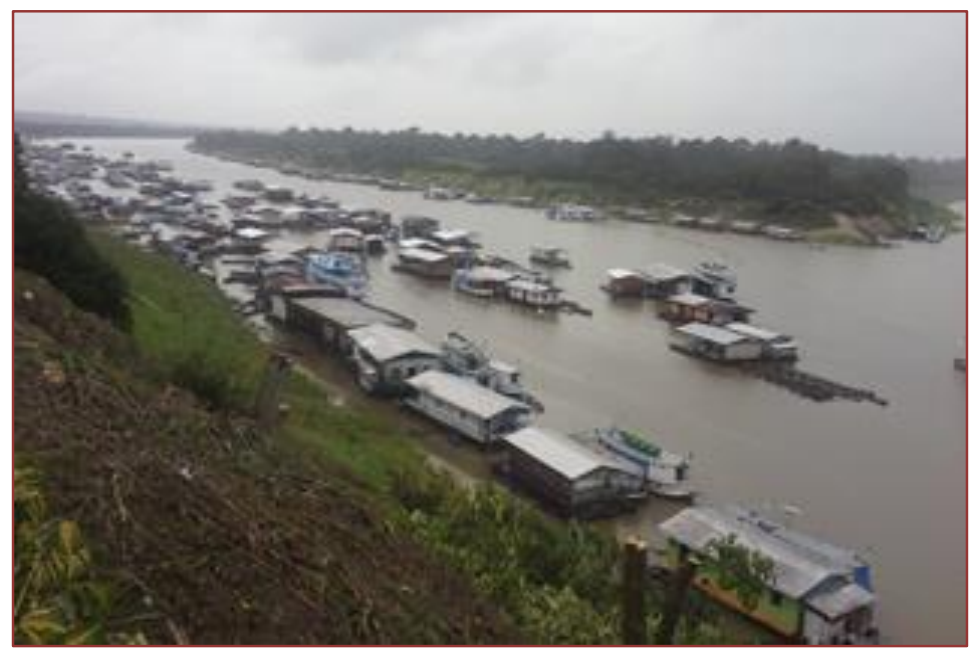

Org.: Zuza (2016)

A migração rural/urbano é um fenômeno presente na cidade Tapauá-AM, e isso faz com que a procura por espaços na superfície aumente, a inexistência de políticas públicas destinadas para o setor habitacional contribui para que os migrantes permaneçam morando em flutuantes, segundo Becker (1990, p. 49).

As políticas de terra e de crédito regulam a atração de migrantes e o grau de fixação: os projetos distribuem a terra, mais só uma parte dos migrantes consegue dela tomar posse, e destes uma parcela expressiva é apropriada por mecanismos burocráticos e creditícios.

Nesse contexto, com a ausência de políticas públicas que visem à expansão da cidade a tendência é que a maioria dos migrantes não procure um espaço na superfície, e mesmo os que procuram encontram diversas dificuldades, a limitação e a valorização dos espaços terrestres, os sistemas de trabalho dos moradores são fatores que contribuem para o aumento do número de flutuantes. 
A falta de planejamento deu inicio a ocupação do espaço urbano fluvial, dando origem a um bairro flutuante, tendo como base que bairro é uma categoria do urbano, caracterizado como cada uma das regiões que se divide a cidade entende-se com isso que bairro, não necessariamente, pode ser definido como parte contida na superfície, nesse sentido Lima (2011, p. 62) destaca que:

Na construção do espaço urbano, o bairro pode ser observado como sendo uma espécie de micro espaço dentro da própria cidade. 0 bairro constitui-se para um grande número de indivíduos, no principal espaço vivenciado ao longo de seu dia-a-dia. É nele que, muitas vezes, os laços de amizade e vizinhança se estreitam criando uma sensação de pertencimento aquele lugar.

Ressalta-se, que o bairro é uma espécie de espaço onde existe como forma de organização na divisão das cidades, surgindo de diversas maneiras, inicialmente sua formação ocorre a partir da expansão e das demandas por moradias, não havendo na maioria das vezes um planejamento adequado, os espaços são modificados ganhando características do urbano, isso faz com que as pessoas busquem novos lugares para morar, considerando que há uma valorização nos espaços disponíveis na cidade.

O bairro pode ser definido ainda como um lugar inserido no espaço urbano em que há um grande número de indivíduos, na maioria dos casos pertencentes à mesma classe social, existem bairros planejados, mais, a maioria surge de forma aleatória com base na ocupação dos lugares, há uma identificação própria daquele lugar, surgindo assim uma relação entre os moradores.

Seabra (2003, p. 72) argumenta que: "É no bairro que diversas experiências da vida social acontecem, tais como a moradia, o comércio, o trabalho, o lazer e outras relações estabelecidas nesse espaço".

Assim, pode se definir o grande número de flutuantes na cidade de Tapauá-AM, como o surgimento de um novo bairro, argumentando que possui características que nos possibilitam fazer tal afirmação, existem moradias e pessoas se relacionando em uma prática social comum de qualquer categoria do urbano, além disso, o comércio está presente de forma significativa em seus diversos ramos, entende-se com isso, que essas características são relevantes para a definição do lugar como bairro.

Os flutuantes por estarem em um número considerável, na margem esquerda, no leito principal e na margem direita do rio onde a sede do município está assentada, aliado com as relações e contradições existentes podem formar um bairro sendo que estão agregados e relacionados com a cidade. Apesar de possuir uma grande extensão territorial, a sede do município possui limitações no espaço da superfície terrestre destinado para residências fixas e pontos comerciais, ficando exposto que não há um planejamento urbano satisfatório na cidade.

Sobre o planejamento para as cidades Rodrigues (2012, p. 213) argumenta que, "Lembramos que a ideologia dominante difunde a noção de que os problemas urbanos são decorrentes a falta de planejamento, da ausência do Estado em prover infraestrutura e equipamentos coletivos"

O Estado deve assumir um papel fundamental, que promova uma infraestrutura adequada na expansão das cidades, esse planejamento deve manter uma organização específica na produção do urbano, para que a cidade ao atingir características mais desenvolvidas ofereça suportes para que sejam instalados pontos de atividades comerciais e residenciais. No caso de Tapauá o município possui o Plano Diretor Municipal, e nele estão contidas alternativas importantes para o desenvolvimento da cidade, como as contidas no capitulo I, artigo 7ํㅜ e incisos I, II, III e IV. ${ }^{16}$

0 artigo $7^{0}$ propõe que haja uma organização no direito de ocupação do solo urbano, em relação à relevância dessa ocupação Carlos (2010, p.47) afirma que: "O uso do solo tem sido analisado a partir da classificação fundamentada nos setores de atividades (industrial e comercial) e no residencial”.

A ocupação do solo urbano tem se dado em uma perspectiva que visa a instalação de residências e comércios, na cidade de Tapauá apesar da grande extensão territorial do município, o solo urbano fica cada dia mais limitado, devido a distribuição de terras desigual que ocorre, ao aplicarmos o questionário para moradores mais antigos notam-se que o espaço fluvial era utilizado apenas como alternativa de pontos comerciais, como postos inflamáveis, pequenas tabernas e bares com atividades festivas nos finais de semana.

16 Art. 7º. O ordenamento do uso e ocupação do solo no Município de Tapauá tem por objetivos: I - estabelecer diretrizes e critérios de ocupação e utilização do solo no cumprimento da função social da cidade e da propriedade; II - ordenar o crescimento do Município visando prevenir e minimizar os impactos ambientais; III - qualificar o meio urbano por meio da urbanização adequada; IV - subsidiar a gestão pública na previsão de ocupação do solo urbano e controle de densidades demográficas. 
A limitação da superfície gerou possibilidades para a construção de casas flutuantes como residências fixas, esse crescimento também no comércio onde novas opções foram inseridas existem pessoas, por exemplo, que possuem 2 (dois) flutuantes, sendo 1 (um) utilizado como residência fixa, e outro utilizado como ponto comercial. Ainda se referindo ao papel do poder público Corrêa $(1989$, p. 24) ressalta que:

No entanto, é através da implantação de serviços públicos, como sistema viário, calçamento, água, esgoto, iluminação, parques, coleta de lixo etc, interessantes tanto as empresas como a população em geral, que a atuação do Estado se faz de modo mais corrente e esperado. A elaboração de leis e normas vinculadas ao uso do solo, entre outras normas do zoneamento e o código de obras, constituem outro atributo do estado no que se refere ao espaço urbano.

O poder público, deve exercer um papel fundamental na construção do urbano, elaborando leis e normas que venham contribuir diretamente no acesso satisfatório a moradia e nos princípios de mobilidade urbana, pois, sabe-se que quando há uma padronização em toda estrutura da cidade, há também um melhor funcionamento dos equipamentos urbanos e problemas como acidentes, deslizamento de terras podem ser evitados.

As denominações religiosas instaladas na cidade percebem o crescimento exacerbado do número de flutuantes, e tem se expandido na área fluvial, e inserem filiais de suas igrejas nesse espaço, buscando com isso adquirir fieis. Ao ser entrevistado um líder religioso, afirmou que, diante das dificuldades de acesso, é mais viável congregar em igrejas construídas nos flutuantes, do que se deslocar para a superfície.

Figura 04: Denominação religiosa na margem esquerda do rio na cidade de Tapauá-AM

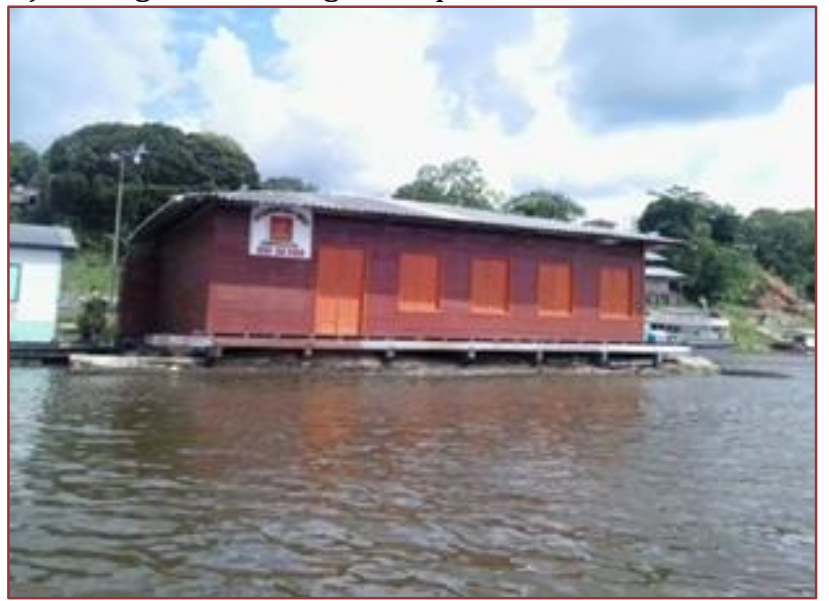

Org. Zuza (2016)

O número de flutuantes na cidade tem dado origem a um novo bairro, visto que esse espaço está próximo ao centro, funcionando assim como um micro espaço onde as relações sociais são evidentes, possuindo características que podem lhe definir como essa categoria do urbano. Á área urbana fluvial de Tapauá é composta por residências fixas, e comerciais em um número considerável que possibilitam essa definição.

\section{CASAS FLUTUANTES COMO ALTERNATIVAS URBANAS}

De acordo com relatos dos moradores entrevistados, em sua maioria pescadores e agricultores, possuem materiais de trabalhos como motores rabeta, canoas, malhadeiras e caixas de isopor, com isso morar em flutuantes se torna mais fácil e prático para fazer o transporte desses instrumentos, tendo em vista que saem de casa pela da manhã e só retornam no período noturno.

Outro motivo encontrado é valorização dos espaços disponíveis na superfície, os moradores afirmaram que na superfície um pequeno espaço que pode ser utilizado para a construção de moradias custa 30 mil reais, valor que vai além da realidade de pescadores e agricultores, sendo o que suas respectivas produções são apenas para os sustentos de suas famílias. 
Sposito (2014, p. 14) argumenta que: "Embutida na origem da cidade há uma diferenciação social: ela exige uma complexidade de organização social só possível com a divisão do trabalho". Compreende-se, que a divisão do trabalho é uma característica da cidade, assim, os que não são detentores de riqueza produzida, são obrigados a morar em áreas periféricas, disponibilizando de benefícios limitados, ou seja, as vantagens da cidade são distribuídas de forma desigual.

A facilidade em adquirir água morando nesses lugares é outra razão que faz com que o crescente número de flutuante permaneça. Os moradores da superfície enfrentam problemas com a falta desse serviço em alguns lugares da cidade. Habitar nas margens do rio torna esse problema ideologicamente resolvido. Quanto ao destino dos resíduos sólidos a coleta ocorre apenas uma vez na semana, e de acordo com relatos dos moradores existem semanas que o serviço não é oferecido, e o lixo é atirado diretamente no rio, sobretudo por moradores do leito principal e da margem direita em que a superfície está mais distante.

Durante as entrevistas os moradores esclareceram que a coleta iniciou-se nos últimos quatro anos, e quando se teve inicio esse serviço, a prefeitura disponibilizava sacolas plásticas para que o lixo fosse recolhido, no entanto, isso deixou de acontecer desde junho de 2015, ressaltaram ainda, que antes os resíduos produzidos eram transportados para a superfície, e em seguida coletado, ou na maioria dos casos eram atirados no rio.

Entender a origem dos moradores dos flutuantes é necessário primeiramente ser feita uma reflexão no que diz Carlos (2010, p. 45) "O uso do solo ligado a momentos particulares do processo de produção das relações capitalistas é o modo de ocupação de determinado lugar da cidade. 0 ser humano necessita para viver, ocupar um determinado lugar no espaço".

Compreende-se que, o uso do solo principalmente o que é destinado para a construção de moradias, é controlado pelo sistema capitalista, e as relações existentes nele são fundamentais para a distribuição dos espaços, nesse sentido, salienta-se que em Tapauá, o solo urbano possui limitações, dessa forma o urbano é expandido para os flutuantes como uma alternativa de adaptação.

Cada momento histórico da cidade possui suas particularidades no quesito da produção do espaço urbano, detentores das riquezas são sempre mais beneficiados independente da época, visto que as relações estão sempre presentes, tornado a distribuição sempre desigual, e, como o ser humano busca sempre lugares para sobreviver, as alternativas são áreas periféricas e de riscos que oferecem o mínimo de conforto e segurança.

A história pode ser explicada de acordo com os fenômenos que nela acontecem, os avanços do sistema capitalista através da ideologia do capital influencia o homem a buscar novas formas de sobrevivência, com base em suas necessidades cotidianas, assim é necessário se padronizar e usufruir das vantagens que surgem no meio social, ou seja, o homem busca se espacializar para que com isso tenha melhores condições de vida, essa melhoria é relativa, tornando-se possível, na maioria, das vezes se houver o fenômeno da migração, isso se reflete nos motivos que levam os moradores dos flutuantes terem migrado para cidade, sendo que antes moravam em comunidades ribeirinhas, mas a busca de melhores condições de educação para os filhos é o primeiro motivo para essa migração, isso é justificado pelo fato de muitas dessas comunidades não possuírem escolas, quando possuem atende apenas a demanda de alunos de ensino fundamental.

Outro fator relacionado à explicação desse fenômeno migratório está na facilidade ao acesso ao sistema de saúde, em todo o território do município de Tapauá apenas 2 (duas) Comunidades Ribeirinhas possuem postos de saúde, além disso, a busca por meios de comunicação mais modernos atrai as pessoas para o espaço urbano, nem todas as comunidades que moravam antes possui energia elétrica. Os moradores salientaram que antes de migrarem, quando se tinha alguma enfermidade era necessário se deslocar até a cidade, em viagens de até dois dias, então preferiram migrar de forma definitiva.

Pontuamos ainda como explicação relevante para a produção do espaço urbano fluvial na cidade de Tapauá-AM a condição financeira dos moradores da cidade, segundo Carlos (p. 2010, p. 46) "Finalmente o uso residencial será determinado pelo papel que cada individuo ocupará (direta ou indiretamente) no processo de produção geral da sociedade e, consequentemente, o seu lugar na distribuição da riqueza gerada".

Dentre os 42 (Quarenta e dois) moradores dos flutuantes entrevistados, (35) são de baixa renda, não possuem empregos fixos, e lucram em torno de 01 (um) salário mínimo mensal, fato que impossibilita uma opção de escolha para a construção de suas moradias, assim aprendem a gostar do lugar que moram. 
Constatou-se nas entrevistas, que existem moradores que residem nos flutuantes a 27 anos, e os que começaram suas trajetórias recentemente, tendo apenas 2 anos morando nesses lugares, geralmente os residentes mais recentes são filhos dos mais antigos, existem também alguns que moravam na superfície, mas venderam suas residências para morar em flutuantes, alegando a facilidade no acesso aos seus materiais de trabalhos.

Alguns empresários que possuem empresas na superfície da cidade já se apropriaram de lugares no espaço fluvial, não para a construção de residências fixas, mas para a inserção de pontos comerciais como fábrica de gelo, postos inflamáveis e flutuantes para a compra de peixes, Corrêa (1989, p.13) diz que:

Os grandes proprietários indústrias e das grandes empresas comerciais são em razão da dimensão de suas atividades grandes consumidores do espaço. Necessitam de terrenos amplos e baratos que satisfaçam requisitos locacionais pertinentes às atividades de suas empresas-junto ao porto, às vias férreas ou em locais de ampla acessibilidade a população etc.

Em Tapauá, os empresários não se apropriam exclusivamente do espaço urbano da superfície, entretanto, o surgimento do bairro flutuante, criou possibilidades para implantação dos serviços, no espaço urbano fluvial, sobretudo de postos inflamáveis, fábricas de gelo, frigoríficos e lojas de alimentos, que já possuem suas instalações comercias na superfície.

Ao serem entrevistados afirmaram que o lucro obtido corresponde com as expectativas, e que diante do aumento do número de flutuantes é necessário expandir os serviços comercias para o espaço fluvial, além disso, destacaram que não obtiveram muitos empecilhos burocráticos na inserção de seus comércios.

É evidente que os residentes do espaço urbano fluvial enfrentam problemas por habitarem nesses lugares, no entanto, a ocupação exacerbada tem se tornado uma dificuldade de todos aqueles que precisam navegar, pois, o fluxo de barcos, canoas, lanchas é intenso o dia todo, sobretudo nos finais de semana, onde muitos acidentes já aconteceram, dando destaque para um ocorrido em dezembro de 2014, onde uma canoa que transportava agricultores, se chocou com uma lancha em que os componentes desenvolviam atividades de lazer, levando a óbito 4 (quatro) pessoas.

Existem residências fixas nas margens esquerdas (onde fica situada a sede do município), no centro do rio e do lado direito, no período da seca os flutuantes ficam muito próximos, e assim as possibilidades de acidentes aumentam.

Os moradores, por sua vez, relataram que a única dificuldade em relação à inserção dos flutuantes, consiste encontrar um lugar ideal para inserir, e que nunca ouviram falar em algum processo burocrático relacionado a isso. Sobre a retirada dos flutuantes salientaram que são a favor, no entanto, esclarecem que o poder o público deve oferecer moradias dignas na superfície.

Diante das análises e entrevistas desenvolvidas, verificou-se que, as dificuldades por morar no espaço urbano fluvial variam de acordo com lugar onde seus flutuantes estão inseridos, os residentes do lado esquerdo, por estarem mais próximos a superfície, são afetados principalmente no período onde as chuvas são mais constantes, visto que precisam todos os dias se deslocar para as escolas, hospital, postos de saúde, bancos, sendo que nenhumas dessas instituições existem no espaço fluvial.

Além disso, é preciso adquirir algum produto na superfície, pois descreveram que os produtos disponíveis nos comércios dos flutuantes possuem um valor mais elevado, o acesso torna ainda mais comprometido, pois ele ocorre com o auxílio de escadarias de madeiras em condições inadequadas, visto que, pode se verificar ausência de equipamentos coletivos, sendo que o porto principal da cidade que oferece recursos adequados para o acesso está localizado em uma distancia considerável da maioria dos flutuantes.

Os habitantes das residências do leito principal do rio possuem os mesmos níveis de dificuldades dos que moram no lado esquerdo, e ainda surgem novos obstáculos, constata-se que o acesso para a superfície é ainda mais dificultoso, pois é necessário ter um transporte adequado para qualquer momento que seja necessário se deslocar, além disso, é no leito principal do rio que está concentrada o maior número de pontos comerciais, a maioria deles não possuem a regularização mínima com o CNPJ, por exemplo.

Aqueles que moram na margem direita possuem ainda maiores obstáculos, pois a superfície se torna ainda mais distante. Além disso, serviços que são comuns em outros lugares, são limitados nessa margem, como exemplo disso cita-se a insuficiência de energia elétrica, esse serviço se faz presente, no entanto, ele possui condições limitadas, sendo impossibilitada a utilização de eletrodomésticos básicos como televisão e geladeira, não suprindo as necessidades dos moradores. 
As casas flutuantes, tornam-se alternativas urbanas na cidade de Tapauá-AM, como residências fixas, destinadas as atividades comerciais, denominações religiosas entre outros, fazendo com que as margens esquerda, direita e o leito principal do rio fiquem com um número excessivo de moradias, causando desconforto para quem tem no rio o principal ponto de acesso para atividades cotidianas, além de contribuir para o aumento da poluição, e até o momento da realização da pesquisa constatou-se que não existe um posicionamento do poder público, para que providências relevantes sejam tomadas.

Fazendo uma análise no contexto histórico das cidades da Amazônia, torna-se visível que em Tapauá, a produção do espaço urbano é um reflexo da divisão de classe, dessa forma, Oliveira (2000, p.22) afirma que:

O espaço urbano que se produz num lugar qualquer da Amazônia não é único, ele está contido e contém uma totalidade que inclui tanto o processo de desenvolvimento recente para a região como a forma como a forma de produção da sociedade nacional, refletindo de maneira da espacialização de outras cidades brasileiras, assinalada pela contradição: de um lado, riqueza e bem-estar e, de outro, pobreza e miséria.

Durante a aplicação do questionário para os moradores pode-se constatar que, a maioria são trabalhadores de baixa renda, que praticamente não possuem alternativas de morarem em outros lugares, sendo que trabalham de forma autônoma e os seus lucros são apenas suficiente para o sustento de suas famílias.

\section{CONSIDERAÇÕES FINAIS}

O espaço urbano fluvial de Tapauá é, resultado de uma completa falta de planejamento, apesar da grande extensão territorial do município, possui grande parte do espaço urbano da superfície limitado, que aliada à reflexão social trás o surgimento de um novo bairro, onde as contradições se fazem presentes de forma visível.

A maioria dos moradores dos flutuantes são pessoas que migraram da zona rural com objetivo de adquirirem melhores condições de vida, como educação, saúde, e a interação com o meio tecnológico que se fazem presente no espaço urbano, considerando que nas comunidades ribeirinhas esses recursos são limitados, e, que de acordo com olhar do ribeirinho esses serviços fazem parte de uma evolução satisfatória, dessa forma, as pessoas sentem a necessidade de evoluir e buscarem um padrão de vida baseado nos princípios capitalistas.

O que hoje é considerado um bairro flutuante necessita de ajustes e da interferência do poder público, levando em consideração que essa alternativa de moradia tem trazido consequências para a as pessoas da cidade como um todo, tendo em vista que acidentes fatais já aconteceram além do crescente índice de poluição. Salienta-se ainda que os moradores podem se organizar em uma associação local, para que assim, possam exigir a disponibilidade de serviços públicos de forma coletiva.

Os moradores possuem suas dificuldades ao acesso a superfície de acordo com o lugar da inserção de seus flutuantes, assim os que estão situados na margem esquerda possuem mais facilidade no acesso as instituições públicas, além de serem moradores mais antigos, que habitam em flutuantes desde o período da migração, os que moram no centro são os que migraram recentemente para a cidade, e não encontraram nem no espaço fluvial um lugar adequado próximo a superfície, no centro se concentra o maior número de pontos comerciais e a maioria das igrejas. Os que moram na margem direita estão mais longe da superfície, e possuem variações quanto ao tempo em que habitam em flutuantes, e assim fazendo parte do espaço urbano fluvial da cidade de Tapauá-AM.

Portanto, a cidade de Tapauá necessita de políticas públicas voltadas para o setor habitacional, não se defende a ideia de que os flutuantes sejam retirados, pois isso mudaria completamente a forma de vida das pessoas, sendo contraditório com seus sistemas de trabalhos, apesar de que muitos moradores concordem com a retirada, pois possuem o desejo de morarem na superfície, no entanto, é necessário que se tenha um controle quanto à ocupação, onde os órgãos competentes responsáveis pelo setor devem manter uma fiscalização com base em princípios constitucionais, tanto na inserção de residências fixas como na de pontos comercias, enquanto não há uma providencia, a tendência é que o número de flutuantes aumente, dificultando ainda mais as navegações de barcos, lanchas e canoas. 
Assim, conclui-se que a produção do espaço urbano fluvial de Tapauá está composta de pessoas que necessitavam de melhores condições de vida, e de se inserirem em atividades coletivas oferecidas somente na cidade. Nesse sentido, torna-se necessário, o próprio governo repensar sobre as questões políticas voltadas para as moradias.

No caso de Tapauá é preciso haver um controle na produção do espaço urbano, uma das alternativas viáveis para a questão seria a criação de novas ruas, ou programas que buscassem oferecer casas populares, é essencial que o plano diretor passe a vigorar na prática, tendo em vista que ele oferece suportes necessários para que as formas de moradias sejam adequadas e não venham comprometer o espaço físico da cidade.

\section{REFERÊNCIAS}

[1] BECKER, K. Bertha. Amazônia. 1ae ed. São Paulo; Ática, 1990

[2] CARLOS, Ana Fani A. A cidade. 1aㅡ ed. São Paulo; Contexto, 2010.

[3] CASTRO, Edna. Cidades na Floresta. 1aㅡ ed. São Paulo; Annablume, 2008.

[4] CORREIA, Roberto Lobato. O Espaço urbano. 1aa ed. São Paulo; Ática S.A, 1989.

[5] LEFEBVRE, Henri. Revolução urbana. Belo Horizonte: UFMG, 1999.

[6] O direito à cidade. Tradução Rubens Eduardo Frias. São Paulo: Centauro, 2001.

[7] LIMA, Maria Eliane Feitosa de. Produção do Espaço Urbano e Impactos Socioambientais na cidade de Manacapuru-AM- O Bairro do Biribiri. Universidade de São Paulo. Departamento de Geografia. Programa de PósGraduação em Ciências Humanas. São Paulo, 2011.

[8] MARTINS, Rosicler. Rodrigues. Cidades Brasileiras. 1aed. São Paulo; Moderna, 1992.

[9] MOREIRA, Ruy. Pensar e ser em geografia. 2a ed. São Paulo; Contexto, 2011.

[10] OLIVEIRA, José Aldemir de. Cidades na selva. 1aㅡ ed. Manaus; Valer, 2012.

[11] RODRIGUES, Arlete Moysés. Planejamento e política urbana: desafios no contexto metropolitano. (p.207) In: FERREIRA, Álvaro (org.) Metropolização do espaço: Gestão territorial e relações urbanas rurais. Rio de Janeiro: Consequência, 2013.

[12] SANTOS, Milton. A Natureza do Espaço: Técnica e Tempo, Razão e emoção. 4⿳a ed. São Paulo: Edusp, 2006.

[13] Por uma Geografia Nova. 6ª ed. São Paulo, EDUSP, 2012.

[14] SEABRA, Odette C.L. Urbanização e fragmentação: cotidiano e vida de bairro na metamorfose da cidade em metrópole, a partir das transformações do Bairro do Limão, Tese (Livre Docência). Universidade de São Paulo, 2003.

[15] SPOSITO, Maria da Encarnação Beltrão. Capitalismo e urbanização. 16a Ed. São Paulo; Contexto. 2014.

[16] TAPAUÁ. Plano Diretor Participativo do Município de Tapauá-AM. Lei Municipal no 237 de 05 de dezembro de 2017, Tapauá, AM: Câmara Municipal, 2007.

[17] TOCANTINS, Leandro. 0 rio comanda a vida: uma interpretação da Amazônia. 9ª ed. Manaus: Valer, 2000. OBRAS CONSULTADAS

[18] FURASTÉ, Pedro Augusto. Normas Técnicas para o Trabalho Científico: Explicitação das Normas da ABNT. 17ä. ed. - Porto Alegre: Dáctilo Plus, 2015.

[19] HARVEY, D. Espaços da Esperança. Tradução de Adail Ubirajara Sobral e Maria Stela Gonçalves. São Paulo: Edições Loyola, 2004. 


\section{Capítulo 10}

\section{"Terra de Nhá Chica": Contradições inerentes à prática turística ${ }^{17}$}

\section{Magno Angelo Kelmer \\ Carlos Eduardo Santos Maia}

Resumo: A cidade de Baependi, localizada no sul de Minas Gerais, foi o local da vida da beata Nhá Chica e, após a sua morte, em 1895, graças e milagres passaram a ser atribuídos a ela. Em 2013 houve a sua beatificação oficializada pelo Papa Bento XVI. 0 número de visitantes interessados em conhecer o local onde a beata viveu e realizou sua obra tem aumentado desde então e Baependi se consolida como destino de Turismo religioso. A reprodução espacial de Baependi conta com modificações atribuídas a tal prática de forma dialética, contraditória e móvel. 0 município já foi conhecido como roteiro de turismo em áreas naturais, devido à variedade de cachoeiras que possui e, na atualidade, enfatizam-se os atrativos religiosos.

Este artigo apresenta o movimento pela beatificação de Nhá Chica e seu uso pela atividade turística, contribuindo na reprodução espacial do Município de Baependi, destacando as contradições inerentes a este processo.

Palavras-chave: Baependi; Turismo religioso; Espaço geográfico.

Texto original intitulado PRODUÇÃO DO ESPAÇO NA “TERRA DE NHÁ CHICA”: CONTRADIÇÕES INERENTES À PRÁTICA TURÍSTICA foi publicado nos Anais do evento SIMGEO: II SIMPÓSIO MINEIRO DE GEOGRAFIA E IV SEMINÁRIO DE PÓS-GRADUAÇÃO EM GEOGRAFIA - 2016. 


\section{INTRODUÇÃO}

Bem-vindo a Baependi, Terra de Nhá Chica! Esta frase está escrita na placa posicionada na BR 267, próxima à entrada do Município de Baependi, no sul de Minas Gerais. Além de informar sobre a principal característica do município na atualidade, ser terra de Nhá Chica, esta deixa clara a força de um elemento em sua organização espacial: a atratividade turística em torno da Beata.

Visitantes são atraídos a Baependi para visitar a Igreja de Nhá Chica, onde encontram-se seus restos mortais depositados em uma urna sob sua estátua e localizados à esquerda do altar do Santuário de Nossa Senhora da Conceição, "Igreja de Nhá Chica". A religiosidade se destaca entre os atrativos do município, devido ao fato deste ter sido palco de atuação de Nhá Chica. Em 29 de março de 1994, a prefeitura, através do decreto de número 299, concedeu em homenagem póstuma o título de cidadania honorária a Nhá Chica, confirmando desta forma, a sua importância para o Município de Baependi.

O município conta atualmente com a presença da atividade turística na qualidade de turismo religioso, no qual visitantes buscam conhecer os atrativos do local onde Nhá Chica viveu. A beata era procurada em vida para realizar bezenções e aconselhamentos, uma vez que, segundo relatos, ela mantinha um contato direto com sua santa de devoção: Nossa Senhora da Conceição que, supostamente, lhe orientava frente aos problemas a ela apresentados. Após sua morte, Nhá Chica passou a ser venerada e, em 2013, sua beatificação foi realizada, impulsionando o fluxo de visitação em Baependi. Desde o ano de 2002, o município participa do Circuito Turístico das Águas como sócio fundador, por ter em suas terras um expressivo número de cachoeiras, servindo como atrativo turístico; fato já utilizado para divulga-lo como destino de turismo em áreas naturais.

Percebe-se em Baependi uma substituição na forma como o município passa a ser divulgado, pois as cachoeiras perderam a centralidade frente aos aspectos religiosos, que no momento atual são mais rentáveis. 0 turismo religioso contribui para a produção do espaço em questão, visto que, os espaços são produzidos dentro da lógica capitalista e seguem as orientações mercadológicas contidas neste modo de produção. A presença da placa na entrada da cidade participa do processo de valorização ao divulgar o atrativo e, ao mesmo tempo, demonstra uma contradição inerente na produção do espaço, pois a imagem do município como "Ser terra de Nhá Chica" não satisfaz a todos os moradores.

\section{A BEATA NHÁ CHICA E O LOCAL DE DESTINO TURÍSTICO}

Francisca de Paula de Jesus, ou Nhá Chica, neta de escravos trazidos de Benguela, nasceu em 1808, em Santo Antônio do Rio das Mortes, distrito de São João del-Rei (MG). Segundo Passareli (2013), em 1814, Izabel, sua mãe, se mudou com os dois filhos, Theotônio e Francisca, para a Cidade de Baependi, em Minas Gerais. Francisca nunca se casou e morava sozinha numa casa simples, sem forro, com chão de terra batida e um fogão à lenha que mantinha acesso para servir um café aos que ali chegavam para buscar uma palavra sábia, amiga e uma promessa de oração (SEDA, 2013), de tal modo que pessoas de muito longe começaram a visitar Baependi para conhecê-la, tornando-a uma projeção de necessidades e desejos humanos, já atraindo visitantes ao seu encontro.

Nhá Chica morreu no dia 14 de junho de 1895. Seus restos mortais, venerados pelos fiéis, encontram-se atualmente no interior do Santuário Nossa Senhora da Conceição, em Baependi, o mesmo local onde existia uma igrejinha construída por ela (PASSARELLI, 2013). Após a confirmação pela Igreja Católica de um milagre a ela atribuído, Nhá Chica foi beatificada no dia 4 de maio de 2013. Hoje é reconhecida como Bem-Aventurada Francisca de Paula de Jesus e o dia 14 de junho, data de sua morte, tornou-se o dia oficial da celebração de sua festa. Com isso, um número crescente de visitantes quer conhecer mais sobre Nhá Chica, fazendo com que o Município de Baependi tenha um maior fluxo de visitação envolvendo a fé, caracterizando a prática do turismo religioso, fato que tem contribuído na sua reprodução sócio-espacial.

Andrade (2000, p.77) conceitua turismo religioso como

o conjunto de atividades, com utilização parcial ou total de equipamentos e a realização de visitas a receptivos que expressam sentimentos místicos ou suscitam a fé, a esperança e a caridade aos crentes ou pessoas vinculadas a religiões. 
Na definição do autor constata-se a importância dos equipamentos para o suporte da visitação turística, ou seja, mudando-se o atrativo novas estruturas são necessárias para sua realização. Surge uma nova produção sócio-espacial que merece ser analisada, pensada e discutida juntamente com a força que a modificou, demonstrando assim, a dinamicidade do espaço como movimento do acontecer.

Compreender os processos de produção e reprodução do espaço significa entendê-los além de um conjunto de formas. É necessário romper com as descrições das funções do espaço e de suas transformações e entender seu processo de produção sócio-espacial, uma vez que a lógica do capital nos impõe uma racionalidade na organização do espaço, programando-o para o consumo, alterando o valor de troca e fornecendo novo sentido para os espaços. Desta forma, para a compreensão da produção e reprodução do espaço é necessário abordar a racionalidade do capital, interpretando suas mudanças e contradições.

O espaço, por ser um produto social, envolve as contradições da realidade à medida que é produzido pelas práticas sociais que o tornam uma mercadoria. Na qualidade de mercadoria, o espaço traduz diferenças e particularidades. Acerca da reprodução do espaço, Lefebvre $(2008$, p.21) contribui ao destacar que o "ordenamento do espaço se dá segundo as exigências do modo de produção (capitalista), ou seja, da reprodução das relações de produção"; no caso específico, a atividade turística classificada como turismo religioso contribui para isto apresentando-se como uma entre as demais presentes em Baependi e contribuindo para seu processo de reprodução espacial.

Faz-se interessante entender o espaço como um produto em formação, uma vez que obra e produto se modificam ao longo do processo histórico, no qual "a obra tem algo de insubstituível e de único, enquanto o produto pode se repetir e resulta de gestos e atos repetitivos" (LEFEBVRE, 2008, p. 63).

A campanha pelo processo de beatificação de Nhá Chica, analisada pela relação obra e produto, cumpre seu papel enquanto obra. 0 processo se deu pela primeira vez em 1952, décadas depois, uma nova instalação da Comissão em prol da Beatificação teve início em 1989, sendo instalada em definitivo aos 14 de janeiro de 1992. Em 2012, o Papa Bento XVI promulgou o Decreto da Beatificação de Nhá Chica, acontecendo a cerimônia oficial em 04 de maio de 2013. Veículos de comunicação notificaram o acontecimento, entre os quais destacam-se: o site oficial de Nhá Chica, o site da Canção Nova, em 28 de junho de 2012, a Rádio Nhá Chica, em 14 de setembro de 2012, o jornal Folha de São Paulo, na edição de 26 de abril de 2013, o site do G1, em 02 de maio de 2013, o site da Uol em 04 de maio de 2013, o jornal 0 Tempo, em 04 de maio de 2013, entre outros.

A partir do momento que a notícia sobre a beatificação foi divulgada, a movimentação de visitantes em torno de Nhá Chica, ocorrida há vários anos no município, ganhou maior expressão, afirmação embasada nas respostas dos moradores e dos turistas que responderam aos questionários. Os moradores mais antigos afirmam que a movimentação existe há muito tempo, pois seus pais contavam sobre os supostos "dons" de Nhá Chica e sobre o povo que a procurava. Questionários foram aplicados em 45 moradores no Bairro Centro, por ser o bairro onde se encontra o santuário e por ser o local de maior visitação, e como resultado, 80\% dos moradores afirmaram que o movimento aumentou após a cerimônia de beatificação. Com base nos questionários aplicados em 96 visitantes, constatamos que 42,7\% estavam visitando Baependi pela primeira vez, destes, $65,8 \%$ foram atraídos à cidade por terem tomado conhecimento sobre Nhá Chica recentemente. A beatificação de Nhá Chica impulsionou a movimentação de visitantes no município e tem contribuído na produção de formas espaciais resultantes da combinação da ação, de um lado, e da estrutura, de outro, sendo estes os dois elementos de organização social analisados por Gottdiener (2010, p.199) ao elucidar que "as formas espaciais são produtos contingentes da articulação dialética entre ação e estrutura".

O Município de Baependi está localizado a $5 \mathrm{~km}$ de Caxambu, a $382 \mathrm{~km}$ da capital do estado, Belo Horizonte, e a $199 \mathrm{~km}$ de Juiz de Fora, principal cidade da Zona da Mata. 0 acesso a Baependi é realizado pelas rodovias estaduais MG-1030 e MG-1045 e pela BR-267. 0 município possui, segundo dados do IBGE/2010, uma população de 18.307 habitantes em uma área de 750,554 $\mathrm{Km}^{2}$. Baependi apresenta-se como uma cidade histórica próxima das estâncias hidrominerais de Caxambu e São Lourenço e possui Aiuruoca, Alagoa, São Thomé das Letras, Conceição do Rio Verde, Caxambu, Pouso Alto, Itamonte e Cruzília como municípios limítrofes. A economia local, antes movida pela agropecuária e pelo comércio, passa a ter na atividade turística um forte movimentador de capital mais recentemente.

Nos levantamentos feitos em trabalho de campo, constatou-se que houve, na última década, um aumento de 2,81\% relacionado a População Economicamente Ativa no setor terciário, setor que compreende as atividades relacionadas ao comércio e à prestação de serviços. Notou-se também um aumento de 6,01\% no setor secundário, fato que está associado a uma maior circulação de capital no município. Ambos 
setores comungam dos benefícios oferecidos pela atividade turística. O setor primário perdeu na década 8,82\% de participação, fato a ser destacado, comprovando uma migração produtiva para outros setores da economia. Atividades relacionadas à prática do turismo podem ser associadas a estas mudanças, uma vez que, a existência da atividade turística, como está ocorrendo em Baependi, faz aumentar a circulação de capital nos setores secundário e terciário.

Para Xavier (2007), a atividade turística ganhou um status de produção na medida em que se tornou uma das ocupações rentáveis do setor terciário com possibilidades de formação pessoal e ampliação na prestação de serviços. Estes dados nos levam a entender que a atividade turística em Baependi participa do "efeito multiplicador do turismo" (Acerenza, 1984; Barreto, 2003; Barreto 2004), não nos atentando ao destino que o volume de capital em circulação irá tomar, mas servindo de base de análise para este trabalho os índices de aumento no número de estabelecimentos relacionados ao turismo no município.

De acordo com dados fornecidos pela Prefeitura Municipal de Baependi, durante a década de 1990 foram concedidos 302 alvarás para estabelecimentos voltados ao setor terciário da economia, destes, 36,7\% relacionados diretamente à atividade turística. Durante a década de 2000, 493 estabelecimentos referentes ao setor terciário foram contabilizados e, destes, 36,5\% ligados diretamente à atividade turística. Na década atual, até a data da coleta dos dados (07/2016), 1064 estabelecimentos do setor terciário foram registrados na prefeitura, dos quais 34,2\% estão ligados diretamente à atividade do turismo. Estes últimos dados confirmam um crescimento no setor terciário em Baependi e apontam para um crescimento no número de atividades relacionadas ao turismo ao registrar um índice próximo das décadas anteriores, restando ainda 4 anos e meio para o fim desta década.

De um município com base na produção agropecuária a um destino de turismo religioso, Baependi conta com uma maior participação do setor de serviços na sua economia. Para Lefebvre (2006), as transformações que a sociedade protagoniza apontam para uma reprodução do espaço onde se incorpora o desenvolvimento da troca. A produção e reprodução do espaço dá-se como realização da mercadoria, na qual tudo é passível de consumo. A partir desta relação capitalista surgem as contradições do espaço, pois os interesses do capital nem sempre são os mesmos da população como um todo.

\section{MAIS QUE UMA PLACA: UMA CONTRADIÇÃO ESTABELECIDA}

A placa posicionada na entrada do Município de Baependi contém, no canto superior esquerdo, o símbolo de informação pública que representa igreja; em sua parte central os dizeres "BEM-VINDO A BAEPENDI TERRA DE NHÁ CHICA"; em sua lateral direita, a imagem de Nhá Chica sentada, como retratada na única foto que se tem registro, cedida pelo médico Henrique Monat em sua entrevista com Nhá Chica, em 1894. Em volta da imagem está escrito FÉ, HUMILDADE, DEVOÇÃO, CARIDADE E AMOR, representando suas Virtudes Heroicas aprovadas pelo Papa Bento XVI aos 14 de janeiro de 2011 (Figura 1).

Figura 1: Placa na BR-267 próximo à entrada do município de Baependi - MG

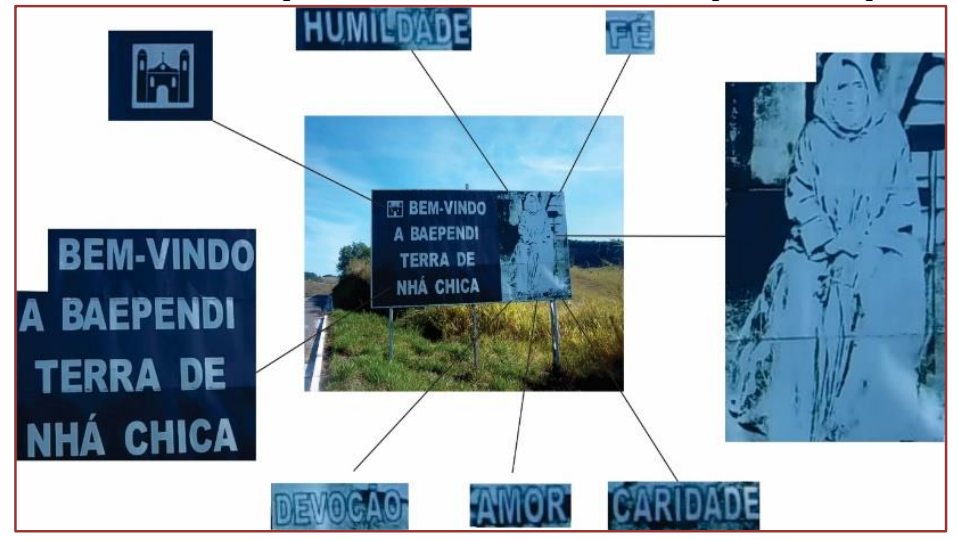

Fonte: Kelmer, trabalho de campo, 2016

Organização; Magno Angelo Kelmer

Entende-se a existência desta placa como um elemento importante na produção espacial de Baependi, posto que anuncia determinada característica do seu espaço que aponta para uma contradição, uma vez que, "SER TERRA DE NHÁ CHICA" não veicula uma propaganda aceita por todos no município. Neste 
momento, analisa-se com base em depoimentos de representantes religiosos, da área turística e de moradores de Baependi em geral esta questão.

Para uma funcionária da Secretaria de turismo de Baependi, a placa pode ser analisada de duas formas. Pessoalmente, ela a identifica como um referencial que trata Nhá Chica como um grande atrativo, sendo que o município dispõe de outros atrativos a serem trabalhados e, principalmente, causa polêmicas entre católicos e evangélicos, os quais colocaram placas na cidade nomeando-a "Terra de Jesus". Segundo a funcionária, já ocorreram manifestações evangélicas em dias e horários de comemoração católica, o que para ela é interpretado como uma "afronta". Como profissional do turismo, não vê problema algum na colocação da placa, uma vez que esta auxilia na divulgação do atrativo turístico, notando-se o interesse profissional da entrevistada em divulgar a imagem de Nhá Chica como atrativo. Sua preocupação com relação a possíveis conflitos religiosos na cidade é pertinente, uma vez que os representantes evangélicos entrevistados são totalmente contra a situação.

O pastor A, responsável por determinada Igreja Evangélica de Baependi, caracteriza a placa como imposição de um fato como verdade. A seu ver, ela não nasceu em Baependi e, mesmo se tivesse nascido, nada dá o direito de afirmar que a terra é de uma só pessoa. "Vivemos em um Estado laico e nada justifica esta placa” (15/01/2016). O pastor afirma que a placa não chega a incomodar, mas não é um ato legal e não representa a população total de Baependi, sendo uma violação. "Se fosse uma placa divulgando um evento não haveria problema, mas um elemento fixo por tempo indeterminado, não está correto" (15/01/2016). Interessante o termo "Estado laico" ter sido citado pelo entrevistado, uma vez que ele relembra uma época passada em que um pastor foi prefeito da cidade e defendia o interesse dos evangélicos.

Para um representante espírita de Baependi não há problema algum com a colocação da placa. Na sua concepção, os espíritas veem Nhá Chica como um espírito protetor da região, entendendo que todo santificado pela igreja é um trabalhador de Deus, sendo um exemplo a ser seguido. "Percebemos problemas com relação aos evangélicos, que não aceitam a situação e falam em Terra de Jesus e não de Nhá Chica" (14/01/2016). O líder espírita encara com preocupação esta situação. Segundo ele, alguns evangélicos chegaram a colocar um adesivo no carro com os dizeres "Baependi, Terra de Jesus", o que para ele é motivo de preocupação, principalmente com católicos que fazem romarias, os que passam o dia na cidade e vão embora. Estes podem ceder a provocações, já que houve momentos de passeatas evangélicas no segundo domingo de dezembro, dia da bíblia, justamente no momento de celebrações católicas pelo dia de Nossa senhora da Conceição, da qual Nhá Chica era devota.

Para o pastor B, representante de outra Igreja evangélica, a placa representa uma forma da Igreja Católica divulgar o nome de Nhá Chica e atrair mais turistas para a cidade. Segundo este pastor, a placa não chega a incomodar, mas poderia ser diferente, destacando características mais gerais do município. 0 pastor afirma que a placa é um marketing para a Igreja Católica divulgar o turismo e não atende aos interesses de todos. 0 entrevistado destaca o fato da Igreja Católica se preocupar muito com as questões financeiras. Interessante esta crítica, uma vez que o templo da Igreja em questão está situado na rua principal da cidade e, além de possuir grandes dimensões, apresenta-se como um dos mais suntuosos.

Compreender o espaço pela fala de quem o habita contribui para o entendimento da sua produção social. Lefebvre (2008, p. 37) destaca que "cada sujeito se situa num espaço onde ele se reconhece ou então se perde, do qual ele usufrui ou modifica", ou seja, no espaço vivenciado pela sociedade, por aqueles que contribuem no seu processo de reprodução. Para estes sujeitos, a experiência do cotidiano (as relações diárias como habitantes) resulta em espaços da representação, nos quais o vivido ganha maior dimensão ao conter as ações e as situações vivenciadas (LEFEBVRE, 2008).

Contribuindo para a compreensão deste espaço da representação, uma representante católica da Associação Beneficente Nhá Chica (ABNC), compreende a placa como referência a uma cidadã de Baependi, uma cidadã que ficou conhecida por seus atos. Para ela, não consta na placa nenhuma denominação de santidade, não estando relacionado a nenhuma religião e não havendo intensão de provocar qualquer pessoa. "Se diz respeito a uma cidadã de Baependi, a placa não incomoda" (15/01/2016). Nota-se uma tranquilidade na fala da entrevistada ao tratar de um assunto que gera polêmica na cidade. Esta tranquilidade pode estar ligada ao fato da Igreja Católica contar com a maioria da população no município e a situação da placa, que está posta, não incomodar. Realmente, não consta na placa alusões a beatificação ou santificação de Nhá Chica, mas o fato de ter um elemento iconográfico representando igreja e as virtudes relacionadas a beata estarem presentes estabelecem uma relação com a Igreja Católica. 
Para determinada obreira da Igreja Universal do Reino de Deus, a placa foi colocada pela Igreja Católica por serem, "infelizmente, maioria na cidade" (16/01/2016). Para ela, trata-se de um fato totalmente errado, uma vez que faltou consciência de quem a colocou, agindo de maneira emocional, ofendendo as demais religiões. "Para nós, não interfere em absolutamente nada, uma vez que a nossa terra, verdadeiramente, não é daqui” (16/01/2016). A entrevistada usou de um ensinamento em que acredita para justificar o uso da expressão terra. Dos entrevistados foi a mais ríspida ao tratar sobre o sentido da imagem contido na placa, fazendo questão de relembrar o episódio no qual o Bispo Sérgio Von Helde, em 1994, ficou conhecido ao chutar em programa de TV a imagem de Nossa Senhora Aparecida demonstrando tratar-se somente de gesso.

$\mathrm{O}$ pastor $\mathrm{C}$, representante de outra Igreja evangélica, entende que a placa diz respeito ao local onde Nhá Chica morou e atendeu ao seu chamado, mas destaca o fato de o dono da terra não ser ela, e sim Deus. 0 pastor faz uma crítica à placa ao afirmar que diz respeito a um meio de divulgação, um marketing, um chamativo da Igreja Católica para ganhar dinheiro com o turismo.

Gottdiener (2010) aposta nas análises para além da materialidade, buscando compreender as relaçõ es entre os processos econômicos, políticos e culturais, ou seja, na relação cotidiana que produz o espaço. Para tal, é necessário ouvir e interpretar o elemento que transita por este espaço, que mantem tais relações, os moradores. Nesse sentido foram entrevistados moradores no intuito de esclarecer melhor a questão estabelecida e, a partir do ponto de vista de quem habita o espaço, apresentar elementos para elucidação deste espaço de representação.

As entrevistas com os moradores revelam uma divisão já esperada com relação à prática religiosa. Categorizamos, para melhor análise, moradores católicos e moradores não católicos, aglutinando as várias filiações religiosas não católicas em um só grupo. Assim, 36 entrevistados afirmaram-se como católicos e 9 entrevistados afirmaram pertencer a outras religiões. Para 93,3\% dos moradores católicos a placa não incomoda, estes concordam com sua existência e seus dizeres. Os depoimentos aludem a grande satisfação em morar em uma terra que é de Nhá Chica, afinal ela viveu e fez sua obra em Baependi. Os católicos que não concordam com a existência da placa alegam que discordam do aspecto comercial que se faz da fé na beata. Com relação à prática da atividade turística do tipo religioso, 66,7\% dos entrevistados católicos concordam com tal prática, alegando maior desenvolvimento econômico para a cidade. Os moradores que não concordam com a prática da atividade turística se dizem incomodados com o uso da fé para o comércio.

Quanto aos moradores não católicos $88,9 \%$ do total de entrevistados sentem-se incomodados com a existência da placa, alegando o fato de Baependi ser "Terra de Jesus". Este grupo reclama da imposição da Igreja Católica ao instalar a placa, beneficiando-se da divulgação da beata. Os moradores não católicos que não se incomodam com a placa, atingindo $11,1 \%$ do total, representam os espíritas. Estes não veem problemas ao relacionar a terra de Baependi com a imagem de uma moradora que tanto fez pela cidade. Do total de entrevistados não católicos, 33,3\% consideram-se satisfeitos com a presença da atividade turística do tipo turismo religioso no município, uma vez que tal fato pode gerar divisas, aumentando a oferta de empregos.

Constatamos in loco que a placa causa polêmica na cidade e muitos não se sentem à vontade para falar sobre a questão. 0 fato destacado diz respeito a uma contradição do espaço, que, para Lefebvre (2008, p. 125) "não é exterior às relações sociais de produção, ainda menos a sua reprodução, que implica estratégias políticas [...] trata-se de uma contradição do espaço". Nota-se que o incômodo com a existência da placa e a interpretação do conteúdo existente nela diz respeito, em grande parte, à prática religiosa. Ser "Terra de Nhá Chica" pode ser compreendido como o local onde a beata viveu e, desta forma, não ter uma conotação de posse do espaço; já para outro grupo de pessoas entrevistadas, ser "Terra de Nhá Chica" remete à posse do espaço, dando à beata e à Igreja Católica um grau elevado de importância e respeito. A presença da placa, ao divulgar uma característica do município, impõe o interesse do capital, utilizando-a como divulgação de um atrativo turístico e atendendo aos interesses da Igreja Católica, reforçando, assim, uma contradição, na qual os interesses não são os mesmos da população como um todo, já que $27 \%$ é representada por não católicos. Contraditório se torna, uma vez que a sociedade capitalista estabelece práticas que transformam a vida de todos em detrimento de alguns. Interessa nesta situação, que faz parte do todo a ser analisado, compreender o movimento inerente à produção espacial. Esta placa analisada faz parte de um conjunto de placas instaladas ao longo da BR267 em um período anterior à data da beatificação. Elas se inserem no contexto de uma série de investimentos do Governo do Estado de Minas Gerais para esta ocasião, fato informado pela funcionária da Secretaria de turismo de Baependi; sendo que "umas foram arrancadas e outras degradadas por ação de pichadores" (14/01/2016). 


\section{BAEPENDI: UMA CIDADE TURISTIFICADA}

Esta situação apresentada refere-se a forma como o município vem sendo divulgado na atualidade, uma vez que a divulgação já foi referente ao Circuito Turístico das Águas, do qual faz parte de acordo com a Lei 2472/02 ao dispor sobre o ingresso como sócio fundador na Associação de Integração Regional do Circuito das Águas e ainda é integrante juntamente com outros nove municípios, à saber: Cambuquira, Campanha, Carmo de Minas, Caxambu, Conceição do Rio Verde, Lambari, Maria da Fé, Soledade de Minas e Três Corações. O Circuito Turístico das Águas foi certificado em 5 de julho de 2005; sua certificação ${ }^{18}$ foi renovada em 2015 e não houve o desligamento do circuito, mas modificou-se a maneira de promover e divulgar o município.

O turismo religioso, enquanto um subsegmento do turismo cultural, contribui para valorizar as diferenças no espaço, pois a fé contribui no processo de diferenciação dos espaços. Santuários, santos e histórias encontrados em um lugar não são os mesmos que se encontram em outros lugares, mesmo sendo caracterizados como espaços do acontecer sagrado. Cria-se o que Lefebvre trata como raridades, tornando bens raros que despertam o interesse para se conhecer. "Os bens que outrora eram raros tornaram-se abundantes, os que eram abundantes tornaram-se raros. Trata-se de um processo em curso, poderoso e irreversível" (LEFEBVRE, 2008, p. 122). Nesta citação, o autor, baseado na crítica feita por Marx à economia política, trabalha a questão dos recursos e sua valorização, ou não, frente à sua quantidade ofertada. Ora, o turismo é uma atividade socioeconômica que se apropria dos espaços e valoriza suas diferenças para torná-las um atrativo, processo sobre o qual, a atividade turística, fará uso como forma de atrair visitantes, utilizando dos atrativos, à maneira de raridades, para aumentar suas demandas.

Figura 2: Placas localizadas próximas a entrada do município de Baependi

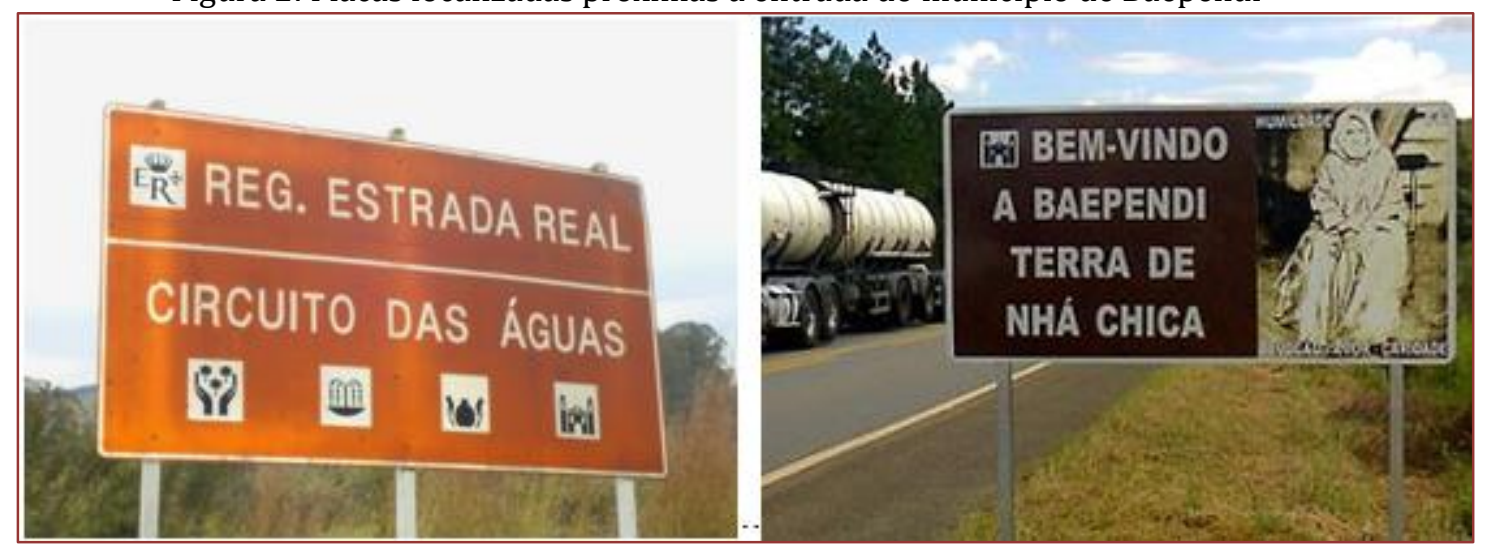

Fonte: (à esquerda: http://rosariaamorim.blogspot.com.br/search/label/S\%C3\%830\%20LOUREN\%C3\%870, à direita: Magno Angelo Kelmer)

Voltemos a analisar a placa na entrada da cidade. Embasados em Lefebvre, como citado acima, as raridades estabelecidas podem nos ajudar a compreender a dinamicidade com que o espaço se modifica. Conforme exposto, o município continua fazendo parte do Circuito Turístico das Águas de Minas Gerais, podendo ser comprovado pela placa à esquerda, mas, o que tem sido mais divulgado na atualidade consta na placa da direita (Figura 2). Nesta lógica, entendemos oferta e demanda, tão trabalhados pela atividade turística, com relação a tornar os bens raros ou abundantes. Os recursos naturais que compõem o circuito das águas continuam a existir. No passado eles atraiam maior demanda turística por serem mais divulgados, o que os tornavam bens raros, despertando o interesse em conhecer. A forma de divulgação e

18 Certificação - A certificação de um Circuito Turístico é o momento em que a instituição é reconhecida oficialmente, pela Setes/MG, como Instância de Governança Regional do Turismo apta para a execução da Política de Regionalização do Turismo do Estado de Minas Gerais. Para ser certificado, o Circuito deve atender a uma série de pré-requisitos, estabelecidos no Decreto Estadual 43.321/2003 e na Resolução SETES no 45/2014, dentre os quais possuir, no mínimo, um ano de existência formal, ser constituído por cinco ou mais municípios de uma mesma região, com afinidades culturais, sociais e econômicas, e ser uma entidade sem fins lucrativos, com a finalidade de promoção e desenvolvimento sustentável do turismo. Disponível em: http://www.turismo.mg.gov.br/noticias/1523-setes-renovacertificacao-dos-circuitos-turisticos Acesso em 07 de dezembro de 2015. 
exploração turística a eles atribuídos foram modificadas, sendo substituídas na atualidade, por um maior interesse nos atrativos religiosos; fato que contribui na produção do espaço criando atrativos e produzindo verdadeiros espaços voltados aos turistas.

As raridades, assim estabelecidas, diferenciam os espaços colaborando no seu processo de (re)produção, produzindo senão "o espaço diferencial" LEFEBVRE (2008, p. 145), sendo este espaço heterogêneo, com possibilidades dadas às práticas sociais; de outra forma, seria um espaço homogêneo, com reduzidas possibilidades; um "espaço de morte" LEFEBVRE (2008, p. 145), havendo uma redução das forças produtivas e das práticas sociais. Nas palavras de Brandão \& Castilho $(2008$, p.82), nestes espaços diferenciados, os elementos que o compõem são particulares de cada localidade,

incluindo-se aí os turistas e todo o staff que lhe dá sustentação - atribuem a cada uma de suas parcelas, além das transformações decorrentes do uso do território turístico, com a incorporação de sistemas altamente tecnicizados que subordinam os estilos de vida e as demais atividades desenvolvidas em localidades receptoras aos ditames da atividade. São reflexões fundamentais para a compreensão das dinâmicas espaciais introduzidas pelo turismo.

A partir do exposto, temos uma diferenciação entre os lugares, uma seleção de localizações e investimentos de acordo com as prioridades de cada atividade. Seria, no entender de Corrêa $(2005$, p. 36), uma seletividade espacial, na qual "no processo de organização de seu espaço o Homem age seletivamente, decide sobre um determinado lugar segundo este apresente atributos julgados de interesse de acordo com os diversos projetos estabelecidos". Lefebvre (2006), ao analisar as transformações que a sociedade vivencia, aponta para a produção do espaço e sua reconstrução como ressignificação, em outro plano, incorporando o desenvolvimento da troca e possibilitando a continuidade da produção, logo, sua reprodução. A produção do espaço dá-se como realização da mercadoria; tudo é passível de mercantilização e consumo. De acordo com Costa (2010, p. 52),

no momento atual da reprodução capitalista, práticas socioespaciais de homens e mulheres são cooptadas e transformadas pela sociedade de consumo, que, ao longo do processo de valorização, agrega valores de uso e de troca a práticas da vida cotidiana que, até um determinado momento da História, eram usos.

Na mesma linha de pensamento, podemos nos embasar nas análises de Lefebvre (2006) ao afirmar que primeiro se estabelece o valor do uso para logo em seguida se estabelecer o valor de troca. Assim, as práticas do modo de produção capitalista transformam valor de uso em valor de troca e a atividade turística contribui na relação dialética valor de uso-valor de troca como movimento de turistificação. Para Nicolas (2001), o processo de turistificação dos espaços implica em substituições dos usos, dentro de uma lógica de produção, na qual a quantidade de lucro indicará qual a melhor opção para determinado momento. Desta forma, ao não mais divulgar Baependi como um destino de turismo em áreas naturais e enfatizar os atrativos religiosos, mais rentáveis no momento, entendemos em Knafou (2001) a participação dos "agentes da turistificação" atuando no espaço, sendo eles: os turistas, o mercado e os planejadores e promotores territoriais; estes últimos, ligados diretamente à gestão do espaço atuam na busca de maiores retornos financeiros.

Em Baependi, os atrativos turísticos religiosos são, no momento presente, mais divulgados, mais valorizados e consequentemente modificam o valor de uso do espaço atendendo aos ideais do modo de produção capitalista. Interessante retornar a fala da funcionária da Secretaria de turismo, a qual afirma que a divulgação sobre Nhá Chica vem tratando-a como um grande atrativo, sendo que o município dispõe de outros atrativos a serem trabalhados. Assim, as ações envolvendo o turismo religioso predominam na atualidade, demonstrando, desta forma, qual o tipo de turismo é mais valorizado e mais divulgado em Baependi.

\section{CONSIDERAÇÕES}

O espaço, por se tratar de um produto social, apresenta contradições inseridas no seu processo de produção e reprodução. A medida que ocorre o processo de reprodução espacial, tornando-o uma mercadoria, o espaço traduz as diferenças e especificidades endêmicas e contradições gerais. Baependi, cidade do sul de Minas Gerais, passa a ter na atividade turística, do tipo turismo religioso, mais um elemento a contribuir no seu processo de reprodução espacial, tornando-se uma característica do município na atualidade. 
Este estudo, ao analisar algumas contradições inerentes à produção do espaço em questão, apresentou aspectos relacionados a mudanças sócio-espaciais, não entendendo a atividade turística somente relacionada aos aspectos econômicos, como geralmente a atividade é analisada, e tampouco a produção do espaço somente como materialidade, e sim na relação dialética entre ação e estrutura.

É fato que a atividade turística motivada pelo turismo religioso está ocorrendo em Baependi em torno da devoção a Nhá Chica e impactando o seu processo de produção espacial mediante a acentuação de determinadas contradições e estabelecendo outras. As contradições fazem parte do processo de reprodução espacial, uma vez que as transformações não atendem a todos da mesma forma. A placa posicionada na entrada do município estabelece uma contradição ao afirmar se tratar da terra de Nhá Chica, fato que não atende a todos os moradores, principalmente os não católicos. A filiação religiosa interfere na maneira como a placa é analisada. Isto posto, há os que a entendem como um sentimento de posse e os que a interpretam como o local de vida de uma pessoa. A presença da placa, apropriada pela atividade turística como forma de divulgação do município, projeta novo valor de uso ao espaço, sendo apropriado numa lógica diferenciada de valor de troca comparativamente àquela estabelecida antanho.

Outra situação que aponta para uma contradição na forma de reprodução espacial de Baependi é a maneira de divulgação de seus atrativos turísticos na atualidade. Os atrativos religiosos ganharam centralidade nas ações frente aos atrativos naturais; fato esclarecedor da relação dialética entre temporalidades e espacialidades, que segundo Lefebvre (2006), ocorrem de maneira desencontrada diante da irredutibilidade do uso na apropriação dos espaços.

Baependi apresenta-se como uma cidade turistificada, na qual, muda-se a forma de sua divulgação, mantêm-se os atrativos turísticos uma vez utilizados, criam-se novos atrativos, transforma-se o espaço e nomeia-o como "Terra de Nhá Chica" ações estratégicas desenvolvidas para atender à lógica do mercado, permeadas por contradições inerentes ao processo.

\section{REFERÊNCIAS}

[1] ACERENZA, Miguel Angel. Administración del turismo. Cidade do México: trillas, 1984.

[2] ANDRADE, José Vicente. Turismo: Fundamentos e dimensões. 8. ed. São Paulo: Ática, 2000.

[3] BARRETTO, Margarita. Manual de iniciação ao estudo do turismo. 13. ed. São Paulo: Papirus, 2003.

[4] . As ciências sociais aplicadas ao turismo. In: SERRANO, Célia; BRUHNS, Heloisa Turini, LUCHIARI, Maria Tereza D.P. (orgs). Olhares contemporâneos sobre o turismo. 3. ed. São Paulo: Papirus, 2004.

[5] BRANDÃO, Paulo Roberto Baqueiro; CASTILHO, Claudio Jorge Moura. Notas para um estudo comparado sobre a formação de territórios turísticos em balneários do Nordeste brasileiro. Revista de Geografia, v. 25, n. 2. 2008, p. 81 - 88.

[6] CORRÊA, Roberto Lobato. Espaço, um conceito-chave da Geografia. In. CASTRO, Iná Elias; GOMES, Paulo Cesar da Costa; CORRÊA, Roberto Lobato. Geografia: Conceito e temas. 7.ed. Rio de Janeiro: Bertrand Brasil. 2005.

[7] COSTA, Carmem Lúcia. Cultura, Religiosidade e comércio na cidade: a festa em louvor à Nossa Senhora do Rosário em Catalão - Goiás. 2010. 223 f. Tese (Doutorado em Geografia Humana) - Universidade de São Paulo, São Paulo. 2010.

[8] GOTTDIENER, Mark. A produção social do espaço urbano. Trad. Geraldo Gerson de Souza. 2. ed. São Paulo: Edusp, 2010.

[9] KNAFOU, R. Turismo e território: por uma abordagem científica do turismo. In: RODRIGUES, Adyr B. R. Turismo e Geografia: Reflexões teóricas e enfoques regionais. 3. ed. São Paulo: Hucitec, 2001.

[10] LEFEBVRE, Henri. A produção do espaço. Trad. Doralice Barros Pereira; Sérgio Martins. (do original La production de l'espace. 4⿳a Ed. Paris Éditions Anthropos, 2000). Primeira versão - fevereiro de 2006.

[12] NICOLAS, Daniel Hiernaux. Elementos para um análisis sociogeográfico del turismo. In: RODRIGUES, Adyr B. R. Turismo e Geografia: Reflexões teóricas e enfoques regionais. 3. ed. São Paulo: Hucitec, 2001

[13] PASSARELLI, Gaetano. Nhá Chica Perfume de Rosa: vida de Francisca de Paula de Jesus. Trad. Cacilda Rainho Ferrante. São Paulo: Paulinas, 2013.

[14] PREFEITURA MUNICIPAL DE BAEPENDI. Decreto no299, de 29 de março de 1994. Dispõe sobre concessão de título de cidadania honorária, em homenagem póstuma. 
[15] . Lei 2472/02, de 06 de agosto de 2002.Dispõe sobre o ingresso como sócio fundador na Associação de Integração Regional do Circuito das Águas.

[16] SEDA, Rita Elisa. Nhá Chica: mãe dos pobres. 1ํe edição. São José dos Campos: Editora ComDeus, 2013.

[17] XAVIER, Herbe. A percepção geográfica do Turismo. São Paulo: Aleph, 2007.

\section{SITES CONSULTADOS}

[1] Nhá Chica. Disponível em: <http://www.nhachica.org.br/sobre-a-nha-chica-historia.php>. Acesso em: 7 de junho de 2015

[2] A beatificação. Disponível em: <http://www.nhachica.org.br/sobre-a-nha-chica-processo-debeatificacao.php> Acesso em 18/01/2016.

[3] BENTO XVI ASSINA DECRETO DE BEATIFICAÇ̃̃O DE NHÁ CHICA. DISPONÍVEL EM: <HTTP://NOTICIAS.CANCAONOVA.COM/BENTO-XVI-ASSINA-DECRETO-DE-BEATIFICACAO-DE-NHA-CHICA/> ACESSO EM 18/01/2016.

[4] Divulgada data da Beatificação de Nhá Chica. Disponível em: <http://www.radionhachica.org.br/servicos-afe-radio-nha-chica.php> Acesso em 18/01/2016.

[5] Cerimônia em Minas vai oficializar primeira beata negra nascida no Brasil. Disponível em: <http://www1.folha.uol.com.br/poder/2013/04/1269202-cerimonia-em-minas-vai-beatificar-primeira-negranascida-no-brasil.shtml> Acesso em 18/01/2016.

[6] BAEPENDI CONTINUA OS PREPARATIVOS PARA A BEATIFICAÇ̃̃O DE NHÁ CHICA. DISPONÍVEL EM: < HTTP://G1.GLOBO.COM/MG/SUL-DE-MINAS/JORNAL-DA-EPTV/VIDEOS/V/BAEPENDI-CONTINUA-OS-PREPARATIVOS-PARAA-BEATIFICACAO-DE-NHA-CHICA/2550164/> ACESSO EM 18/01/2016.

[7] FILHADE ESCRAVA, NHÁCHICAÉBEATIFICADAEMMINASGERAIS. DISPONÍVELEM:

<HTTP://NOTICIAS.UOL.COM.BR/COTIDIANO/ULTIMAS-NOTICIAS/2013/05/04/NHA-CHICA-PRIMEIRA-BEATANEGRA-DO-BRASIL-E-RECONHECIDA-NESTE-SABADO.HTM> ACESSO EM 18/01/2016.

[8] Mineira de Baependi, Nhá Chicaéa 1 ${ }^{a}$ negra a ser beatificada no Brasil. Disponível em: <http://www.otempo.com.br/cidades/mineirade-baependi-nh\%C3\%A1-chica-\%C3\%A9-a-1\%C2\%AA-negra-a-ser-beatificada-no-brasil-1.638768> Acesso em 18/01/2016.

\section{ENTREVISTAS}

[1] Funcionária da Secretaria de turismo de Baependi. Depoimento. [14 de janeiro de 2016]. Baependi: Entrevista concedida a Magno Angelo Kelmer.

[2] Obreira da Igreja Universal do Reino de Deus. Depoimento. [16 de janeiro de 2016]. Baependi: Entrevista concedida a Magno Angelo Kelmer.

[3] Pastor A responsável pela Catedral das Assembleias de Deus. Depoimento. [15 de janeiro de 2016]. Baependi: Entrevista concedida a Magno Angelo Kelmer.

[4] Pastor B responsável pela Igreja Metodista. Depoimento. [15 de janeiro de 2016]. Baependi: Entrevista concedida a Magno Angelo Kelmer

[5] Pastor C responsável pela Igreja do Evangelho Quadrangular. Depoimento. [18 de julho de 2016]. Baependi: Entrevista concedida a Magno Angelo Kelmer.

[6] Representante da Igreja católica responsável pela Associação Beneficente Nhá Chica (ABNC). Depoimento. [15 de janeiro de 2016]. Baependi: Entrevista concedida a Magno Angelo Kelmer.

[7] Representante espirita do Centro Espírita Ressureição e Vida. Depoimento. [14 de janeiro de 2016].

[8] Baependi: Entrevista concedida a Magno Angelo Kelmer. 


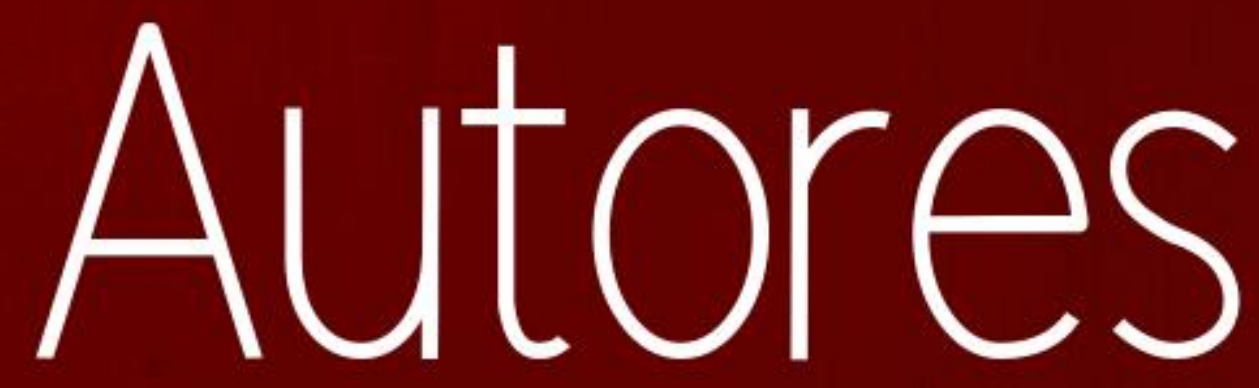




\section{FABIANE DOS SANTOS (ORGANIZADORA)}

Mestre em geografia pela Universidade Federal de Uberlândia, na área de planejamento ambiental, atuante em geociências, com ênfase em ambiental - áreas verdes, índice de áreas verdes, espaços públicos livres e parques urbanos. Possui graduação em Geografia (Licenciatura e Bacharelado) pela Universidade Federal de Uberlândia, mestrado em geografia pela Universidade Federal de Uberlândia. Tem experiência na área de Geociências, com ênfase em Geografia ambiental, atuando principalmente nos seguintes temas: áreas verdes, índice de áreas verdes, espaços públicos livres e parques urbanos.

\section{ABRAÃO FERREIRA ZUZA}

Graduado em Licenciatura em Geografia pelo Centro de Estudos Superiores de Tefé, da Universidade do Estado do Amazonas e Mestre e geografia pela Universidade Federal do Amazonas sob orientação de Dra. Paola Verri de Santana, cuja dissertação foi intitulada: 0 abastecimento energético em cidades da linha do Gasoduto Urucu-Coari-Manaus.

\section{ALEX DE LIMA SANTOS}

Bacharel e Licenciado em Geografia pela Universidade Federal do Amapá (2010), Bacharel em Direito pela Faculdade Estácio de Macapá (2017).

\section{ALLISON BEZERRA OLIVEIRA}

Possui graduação em Geografia e Especialização em Planejamento e Gestão Ambiental pela Universidade Estadual do Maranhão - UEMA, Mestrado e Doutorado em Geografia pela Universidade Federal de Pernambuco - UFPE. É Professor Adjunto do curso de geografia da Universidade Estadual da Região Tocantina do Maranhão - UEMASUL. É líder do Grupo de Pesquisas Socioeconômicas do Maranhão - GPS. É revisor de revistas científicas e consultor ad hoc da Fundação de Amparo à Pesquisa e Desenvolvimento Científico do Maranhão - FAPEMA. Como geógrafo atua na área de Geografia Econômica e Regional

\section{AMOM CHRYSTIAN DE OLIVEIRA TEIXEIRA}

Professor da Universidade Estadual de Goiás, Câmpus Nordeste

\section{CARLOS EDUARDO SANTOS MAIA}

Possui graduação em Bacharelado em Geografia pela Universidade do Estado do Rio de Janeiro (1987), graduação em Licenciatura em Geografia pela Universidade do Estado do Rio de Janeiro (1988), mestrado em Geografia pela Universidade Federal do Rio de Janeiro (1994) e doutorado em Geografia pela Universidade Federal do Rio de Janeiro (2002). Atualmente é professor associado no DEGEO/UFJF, pesquisador do NuGea e atua como colaborador no Programa de Pós-Graduação em Geografia do IESA/UFG. Tem experiência na área de Geografia, com ênfase em Geografia Cultural, atuando principalmente nos seguintes temas: tradições, rituais e festas populares. Bolsista CAPES de Pós doutorado no ENEC/Sorbonne/Paris IV (2015).

\section{CATHERINE PROST}

Possui mestrado (DEA) em Géopolitique - Université de Paris VIII (1993) e doutorado em Géopolitique - Université de Paris VIII (1999). É professora adjunto da Universidade Federal da Bahia (UFBA). Tem experiência na área de Geografia, atuando principalmente nos seguintes temas: pesca artesanal, manejo de recursos naturais, impactos ambientais, organização social, reserva extrativista, populações tradicionais. 


\section{DAVIS GRUBER SANSOLO}

Professor da Universidade Estadual Paulista - UNESP, Campus Litoral Paulista. Graduação em Geografia pela Universidade Federal do Rio de Janeiro (1987), Mestrado em Geografia Física pela Universidade de São Paulo (1996) Doutorado em Geografia Física pela Universidade de São Paulo( 2002). Pós Doutorado na COPPE, UFRJ, 2007. Vice-Coordenador Executivo do Insituto de Políticas Públicas e Relações Internacionais-IPPRI. Coordenador do Programa de Pós-Graduação em Desenvolvimento Territorial na América Latina e Caribe - Territorial. Líder de grupo de pesquisa sobre Conservação da Natureza da Zona Costeira e Coordenador do Laboratório de Planejamento Ambiental e Gerenciamento Costeiro - LAPLAN. . Atua na área de Geografia, com ênfase em planejamento e gestão ambiental, gerenciamento costeiro integrado, áreas protegidas, comunidades tradicionais e desenvolvimento territorial

\section{DIOGO BERNARDINO SANTOS DE MEDEIROS}

É Mestre em Geografia pela Universidade Federal do Rio Grande do Norte (PPGE/CCHLA, 2019), onde também graduou-se como Bacharel em Geografia (DGC/CERES, 2016) e, desde 2017, cursa a Licenciatura Plena em Geografia (DGC/CERES).

\section{ELIANE SIMÕES}

Pesquisadora e consultora em projetos socioambientais, com foco em conservação ambiental, sobreposições territoriais áreas protegidas e territórios tradicionais, planejamento participativo; bióloga com mestrado em Educação, Doutorado Interdisciplinar em Ambiente e Sociedade e Pós Doutoramento em Adaptação a Mudanças Climáticas na Região Costeira. Atuou durante 28 anos na gestão da conservação no governo do estado de São Paulo: coordenadora do Núcleo de Áreas Marinhas Protegidas, gestora do Núcleo Picinguaba do PESM e coordenadora dos Programas de Uso Público, Pesquisa e Interação Socioambiental dessa mesma unidade.

\section{ÉLIDA THALITA SILVA DE CARVALHO}

Mestra, Geógrafa e Licenciada do curso de Geografia pela Universidade Federal do Rio Grande do Norte. Técnica em Estradas pelo Instituto Federal do Rio Grande do Norte.

\section{EMERSON COSTA DE MELO}

Doutor em Geografia (UERJ), Mestre em Geografia (UFMG), Bacharel e Licenciado em Geografia (PUC/SP).

\section{EUBIA ANDRÉA RODRIGUES}

Graduada em Geografia pela Universidade Federal de Juiz de Fora-MG, mestre em Geografia pela Universidade Federal do Amazonas sob orientação da Dra. Tatiana Schor. Atualmente, é professora Assistente da Universidade do Estado do Amazonas, no Centro de Estudos Superiores de Tefé, atuando na Faculdade de Geografia desde 2004. Desenvolvendo pesquisas na área de Geografia Urbana, Geografia Agrária e Ensino de Geografia

\section{IOLANDA LOPES DE OLIVEIRA}

Mestre em Geografia pelo Programa de Pós-Graduação em Geografia da Universidade Federal de Santa Maria. Licenciada em Geografia pela Universidade Federal do Mato Grosso.

\section{JEFERSON JOSÉ DE OLIVEIRA PINHEIRO}

Graduado em Geografia pela Universidade do Estado de Minas Gerais (UEMG). Atuou como pesquisador do NEAB - Núcleo de Estudos Africanos e Afro-brasileiros e do Núcleo de Estudos sobre Diversidades Socioculturais e Produção do Espaço - atua principalmente na área de Geografia 
Cultural no campo das africanidades e afro-brasilidades. Desenvolveu trabalhos envolvendo Geografia e Literatura afro-brasileira. Atuou como colaborador no projeto de extensão "Rompendo Fronteiras: a Geografia para além dos muros da universidade". Além disso, foi bolsista de Iniciação Científica do projeto "Gênero e sexualidades na construção de espacialidades das juventudes em Carangola(MG). Atualmente, trabalha como professor de Geografia na escola em tempo integral Henrique Coutinho, Iúna-ES.

\section{JOÃO PAULO DE ALMEIDA AMORIM}

Doutorando em Geografia pela Universidade Federal do Rio Grande do Norte.

\section{JÚLIA DINIZ DE OLIVEIRA}

Doutoranda em Geografia pela Universidade Federal do Rio Grande do Norte.

\section{JULIANA MARCONDES BUSSOLOTTI}

Graduada em Comunicação e Artes pela Universidade de São Paulo, pós-graduação lato sensu em Designer Instrucional pela Universidade Federal de Itajubá, mestre em Ciências Ambientais pela Universidade de Taubaté e doutora em Geografia pela Universidade Estadual Paulista. Atualmente é pesquisadora da Universidade Estadual Paulista (pós-doc Programa de Pós-Graduação em Desenvolvimento Territorial na América Latina e Caribe - TerritoriAL), faz parte da diretoria da Associação Cunhambebe da Ilha Anchieta. Professora assistente III da Universidade de Taubaté, professora coordenadora adjunta do Mestrado Profissional em Educação da Universidade de Taubaté, professora e conselheira - CONDEP do Departamento de Gestão e Negócios - Gen, integrante da Comissão Própria de Avaliação - CPA - UNITAU, conselheira do Comitê de Ética em Pesquisa - CEP - UNITAU, professora coordenadora do curso de geografia EAD da Universidade de Taubaté e coordenadora do Programa da Pró-Reitoria de Extensão - PROGRAMA TRILHA DE APRENDIZAGEM: Protagonismo, Empreendedorismo e Inovação.

\section{LUCILÉA FERREIRA LOPES GONÇALVES}

Possui doutorado em Geografia pela Universidade Federal do Paraná (2016);mestrado em Geografia pela Universidade Federal do Paraná(2010); mestrado em Educação pelo INSTITUTO PEDAGÓGICO LATINOAMERICANO Y CARIBENO (2000); Especialização em Geografia e Planejamento Ambiental PUC- Minas (1994); Bacharel pela Universidade Federal do Maranhão (1989) e Licenciada em Geografia pela Universidade Estadual do Maranhão (1995). É professora Adjunto na Universidade Estadual da Região Tocantina do Maranhão - UEMASUL; professora do Estado do Maranhão, nível médio. Tem experiência na área de Geografia, com ênfase em Geografia, atuando principalmente nos seguintes temas: Geografia Cultural,Ensino de Geografia; Geografia do Maranhão; Evolução do Pensamento Geográfico; Educação ambiental e Educação.

\section{LUÍS RICARDO SOARES WENCESLAU}

Possui graduação em Licenciatura em Geografia pela Universidade do Estado de Minas Gerais (UEMG) - Unidade Carangola, mesma instituição em que foi estagiário do curso em 2017 - 2018 e colaborador de projetos de extensão que versam sobre a temática educacional da Geografia. Além disso, foi pesquisador do Núcleo de Estudos Africanos e Afrobrasileiros - NEAAB/Carangola (2016 2018), no qual aprofundou os conhecimentos acerca das relações etnicorraciais e da cultura africana na diáspora. No ano de 2019, trabalhou como professor regente de aulas na Educação Básica do Estado de Minas Gerais. Atualmente, é mestrando em Geografia na Universidade Federal de Viçosa (UFV). Desde então, dedica suas pesquisas na área de Geografia Humana com ênfase em Geografia Cultural, Geografia da Religião e Geohistória. 


\section{LUIZ FELIPE SAUSEN DE FREITAS}

Mestre em Geografia pelo Programa de Pós-Graduação em Geografia da Universidade Federal de Santa Maria. Licenciado em Geografia pela Universidade Federal de Santa Maria.

\section{MAGNO ANGELO KELMER}

Mestre em Geografia pela UFJF (Universidade Federal de Juiz de Fora) na linha de pesquisa Dinâmicas sócio-espaciais (2017), graduado em Geografia pelo CES (Centro de Ensino Superior de Juiz de Fora) (2006) e possui Especialização em Geografia: Pesquisa e Ensino pelo CES (Centro de Ensino Superior de Juiz de Fora) (2008). Lecionou no Centro Universitário Estácio Juiz de Fora, nos cursos de Turismo, Engenharia de produção, Engenharia Civil e Pedagogia. Atualmente é professor do Colégio CNEC Juiz de Fora, lecionando no ensino fundamental e ensino médio. Tem experiência na área de Geografia, com ênfase em Geografia Humana, atuando principalmente nos seguintes temas: espaço geográfico, turismo e produção e formação sócioespacial.

\section{MARIA ELISA ZANELLA}

Professora do Departamento de Geografia da Universidade Federal do Ceará

\section{MAURICIO SANTANA MOREAU}

Professor da Universidade Estadual de Santa Cruz

\section{ROBERTO BARTHOLO}

Professor Titular da UFRJ. Atua na área de Gestão e Inovação do Programa de Engenharia de Produção da COPPE/UFRJ, onde coordena o Laboratório de Tecnologia e Diálogos e Sítios (LTDS). É graduado em Economia pela UFRJ e em Teologia pela PUC/Rio, com mestrado em Pesquisa Operacional pelo Programa de Engenharia de Produção da COPPE/UFRJ e doutorado em Antropologia Filosófica. pela Universidade de Erlangen-Nürnberg (Alemanha). Sua atuação acadêmica cobre os campos temáticos de humanidades digitais, patrimônio relacional e empreendedorismo situado.

\section{SALETE KOZEL TEIXEIRA}

Possui graduação em Geografia pela Faculdade Estadual de Educação Ciências e Letras de Paranavaí (1970), mestrado em Geografia (Geografia Física) pela Universidade de São Paulo (1993) e doutorado em Geografia (Geografia Física) pela Universidade de São Paulo (2001))com estágio na Universidade Paris IV Sorbonne-França. Atualmente é professora aposentada da Universidade Federal do Paraná com atuação pós-graduação na área de Geografia. Integra a linha de pesquisa Território,Cultura e Representação, priorizando os seguintes temas: Geografia, ensino e representação, Estudos de percepção em geografia, Mapas Mentais linguagem e representação, Geografia e manifestações culturais. Pós-doutorado no IESA/ LABOTER da Universidade Federal de Goias. Professora convidada pela Universitá degli studi di Trento (Itália). Integrante da rede NEER (Núcleo de Estudos em Espaço e Representação)

\section{SEVERIANO JOSEH DOS SANTOS JR.}

Possui doutorado em Geografia pela Universidade Federal da Bahia, mestrado em Engenharia de Produção pela Universidade Federal do Rio de Janeiro (2000) e graduação em Geografia pela Universidade Federal da Bahia (1987). Atualmente é professor EBTT do Instituto Federal da Bahia, campus Salvador, no qual faz parte do Departamento de Geografia. Sua tese, "Zelosamente habitando a Terra. Ecovilas genuínas, espaço geográfico e a construção de lugares zelosos em contextos contemporâneos de fronteiras paradigmáticas" expõe seu interesse transdisciplinar sobre o desenvolvimento de tecnologias sustentáveis e ecológicas e a geografia do sagrado, o vínculo ontológico do humano com a ética do zelo pela Terra, a partir do enraizamento das comunidades nos solos do lugar zeloso e na unicidade do Cosmos. É membro voluntário (área de ambiente e 
cidadania), habita e participa desde os primórdios da Fundação Terra Mirim. Tem experiência na área de Geografia, Geografia do Sagrado, Antropologia Filosófica, Desenvolvimento Sustentável, Ontologia do Espaço, Sociologia Contemporânea, atuando principalmente nos seguintes temas: geografia, natureza, ontologia do ethos, técnica, tecnologias e sustentabilidade, comunidade, territorialidades contemporâneas, meio ambiente e educação.

\section{SIDNEI RAIMUNDO}

Professor Associado da Escola de Artes, Ciências e Humanidades da Universidade de São Paulo (EACH-USP). Doutor em Geografia (na área de análise ambiental e dinâmica territorial) pela Universidade Estadual de Campinas (UNICAMP), mestre em Geografia (Geografia Física) pela Universidade de São Paulo (USP), bacharel e licenciado em Geografia também pela USP. Realizou estágio pós-doutoral na Universidade de Girona, Espanha. Trabalhou no Instituto Florestal do Estado de São Paulo, com manejo (gerenciamento) de parques, estações ecológicas e outras áreas protegidas. É professor da EACH-USP, onde também orienta nos programas de pós-graduação em "Mudança Social e Participação Política" e em "Turismo". É coordenador do curso de Lazer e Turismo da EACH-USP, gestão 2020-2022.

\section{THIAGO AMANCIO GONÇALVES}

Professor de Geografia da Rede Estadual de Ensino do Tocantins Graduado em Geografia pela Universidade Estadual de Goiás (UEG) - Câmpus Nordeste

\section{THIARA MESSIAS DE ALMEIDA TEIXEIRA}

Professora da Universidade Estadual de Goiás, Câmpus Nordeste

\section{VERA MARIA FAVILA MIORIN}

Docente do Programa de Pós-Graduação em Geografia da Universidade Federal de Santa Maria. 
